\title{
The Six Vowel Hypothesis of Old Chinese in Comparative Context
}

\author{
Nathan W. Hill
}

\author{
中國語言自集刊 \\ Bulletin of Chinese Linguistics \\ 第六卷第二期 Volume 6 Number 2 \\ 二零一二年十二月 December 2012 \\ ISSN: 1933-6985
}

紀念李方桂先生中國語言學研究學會

Li Fang-Kuei Society for Chinese Linguistics

香港科技大學中國語言學研究中心

Center for Chinese Linguistics, HKUST 
$\longrightarrow$ 


\title{
The Six Vowel Hypothesis of Old Chinese in Comparative Context
}

\author{
Nathan W. Hill \\ School of Oriental and African Studies, University of London \\ Gong Hwang-Cherng in two papers $(1980,1995)$ collected a number of \\ cognate sets among Chinese, Tibetan, and Burmese. This paper reexamines these \\ cognate sets (base on Gong 1995) using a six vowel version of Old Chinese, \\ specifically the Baxter-Sagart system. In light of six vowel theory it is possible \\ both to be more confident about some cognate sets and possible to reject or \\ revise others.
}

Keywords: Old Chinese, Old Burmese, Old Tibetan, vowels

\section{Introduction}

In 1980 Gong Hwang-cherng brought together a large body of potential cognates among Chinese, Tibetan, and Burmese, with an eye to tracing the development of the vowels in these three languages form a putative common ancestor (Gong 1980/2002). ${ }^{1}$ Fifteen years later Gong refined his analysis focusing on the final consonants as well as the vowels and adding Tangut comparisons (Gong 1995/2002). In both papers Gong employed the Old Chinese reconstructions of Li Fang-kuei (1971, 1974-1975). Li's

\footnotetext{
${ }^{1}$ This essay uses the Library of Congress system for transliterating Tibetan with the exception that the letter $a$ is transliterated as " $h$ " rather than with an apostrophe. The Library of Congress system is used for Burmese also, with the exception that heavy and creaky tones are transliterated as $h$ and ? rather than " and '. For Chinese I provide the character followed by Baxter's Middle Chinese (1992), an Old Chinese reconstruction taken from or compatible with the current version of Baxter and Sagart's system (2011), and the character number in Karlgren (1957). Like in Baxter's own recent work, for Middle Chinese I use "ae" and "ea" in place of his original " $¥$ " and " $\varepsilon$ ". I do not however following him in changing " $i$ " to "+". Old Chinese reconstructions lacking in Baxter and Sagart (2011) I reconstruct myself, often relying on Schuessler (2009); my reconstructions these are preceded by \# rather than *. I omit features of Baxter and Sagart's system, such as pointed brackets, intended only to exhibit morphological structure. For Tibetan verbs that undergo stem alternation I cite only the verbal root; if the verb exhibits voicing alternation I favour the voiceless form (cf. Hill 2010). I would like to thank Guillaume Jacques and Zev Handel for comments on earlier versions of this paper, and the British Academy for support during its revision.
} 
system has the four vowels, i, $u, 2$, and a, and the three diphthongs, ia, ia, and ua ( $\mathrm{Li}$ 1971:24, 1974-5:247). Another feature of Li's Old Chinese is a series of both voiceless and voiced stop codas, resulting in an absence of open syllables (1971:25, 1974-5:249); $\mathrm{Li}$ is however circumspect about the phonetic reality of -b, -d, and -g (1971:33, 19745:249). Today Li's system has few adherents; instead, most researchers employ a system that has six nuclear vowels ( $a, e, i, o, u$, and $ə$ ), lacks voiced codas, and allows for open syllables.

The six vowel theory is the result of combining four hypotheses: the "front vowel hypothesis" (Baxter 1992:240-247), the "r-hypothesis" (Baxter 1992:259-267), the "rjhypothesis" (Baxter 1992:280-288) and the "rounded vowel hypothesis" (Baxter 1992: 236-240). The "front vowel hypothesis", proposed by Arisaka Hideyo (1937-1939 /1957:354-355, 1961:69-70), holds that division four (四等) words originate from front vowels rather than a palatal medial. The "r-hypothesis", proposed by Sergei Jaxontov (1960a:2-9, 1963:90-93), accounts for the origins of second division (二等) words with a medial -r- ${ }^{2}$ Edwin Pulleyblank accepted this proposal, and added to it the "rj-hypothesis", that chóngniǔ division three (重紐三等) words also originally had a medial -r- (1962:111-114). Jaxontov also first articulated the "rounded vowel hypothesis", that Middle Chinese -w- results from the breaking of rounded vowels before dentals, or the re-phonemization of labiovelar initials (cf. Jaxontov 1960b esp. p. 104, 1970 esp. p. 54). ${ }^{3}$ Jaxontov's combination of these three hypotheses results in a seven vowel system with rather restricted distribution (1965:27, 1978-79:37).

In a lecture delivered at Princeton University in 1971 Nicholas Bodman modified the system of Jaxontov to yield six vowels with a more balanced distribution; Bodman's student William Baxter was the first to publish this proposal (Baxter 1980). The evidence for the six vowel hypothesis reached its culmination in Baxter's use of statistical methods to prove that it accounts for the rhymes of the 詩經 Shījing better than previous systems (Baxter 1992). Independently of Baxter, Sergei Starostin arrived at a similar system (1989). ${ }^{4}$ Since circa the turn of the millennium Baxter has worked with Laurent Sagart on further refining Baxter's 1992 system. Although they have now made various modifications to the initials, the only change to the rimes is the addition of a final -r, following a suggestion of Starostin (1989:399-407).

In Gong's words “the development of comparative Sino-Tibetan linguistics is

2 Jaxontov originally proposed medial -1-, but subsequent researchers have generally amended this to -r-. (cf. Baxter 1992:262).

3 Pulleyblank independently arrived at the same hypothesis a few years later (cf. Pulleyblank 1962:141-142). However, he abandoned this proposal the next year (1963:207-208) and remains a vocal opponent (2000:33).

${ }^{4}$ Zhengzhang (2000:33-42) and Schuessler (2009) also accept the six vowel hypothesis. 
closely connected with progress made in the field of Chinese historical linguistics" (1980/2002:1). The "1.00" version of Baxter and Sagart's system of reconstruction is now available on line (2011), allowing for a convenient reexamination of Gong's comparisons. ${ }^{5}$ Inevitably the six vowel theory will affect both the plausibility of Gong's comparisons and the ultimate form of the Ursprache. The current paper presents the evidence Gong assembled in the light of the reconstructions of Baxter and Sagart (2011). I follow Gong's example in first examining the nuclear vowels of Chinese, Tibetan, and Burmese, leaving for the future a full consideration of final consonants and Tangut comparisons. I include all forms discussed in Gong (1995/2002) and add a few, which Gong does not include but are widely found in the secondary literature. Appendix 2 provides a concordance of Gong's comparisons and the comparisons made here. Any lexical amendments to Gong's proposals (such as the comparison of 虺 rather than 閩 to Tibetan sbrul "snake"), I mention in the footnotes. Also in the footnotes I draw attention to potential irregularities among the codas and initials.

\section{Burmese and Tibetan historical phonology}

In his comparisons Gong (almost always) uses Written Burmese and Written Tibetan rather than Old Burmese and Old Tibetan. Written Burmese is an idealized standard, which develops from Old Burmese, reflecting the usage of no specific time or place, whereas Old Burmese reflects the usage of Burmese speakers in Pagan at the time of the Pagan dynasty (1113-1287 CE). Although Gong avoids Old Burmese data, he generally has a correct understanding of developments between Old Burmese and Written Burmese. Gong acknowledges three changes between these two periods of the language.

\footnotetext{
5 Baxter and Sagart have not provided an accompanying discussion of their reconstruction system. However, many of the more recent ideas can be gleaned from Sagart (1999) and Sagart and Baxter $(2009,2012)$. Another valuable resource is the video-recordings of the "Summer School on Old Chinese Phonology" (École des Hautes Études en Sciences Sociales, Paris, 2-4 July 2007) available at http://semioweb.msh-paris.fr/AAR /1071/liste conf.asp?id $=1071$ (accessed 24 February 2012).

6 For a discussion of the primary sources of Old Burmese philology and their research see Frasch (1996:1-16). For a discussion of the standardization of Written Burmese orthography see Nishi (1999:1-26).
} 
iy > e (Nishida 1955:28-9, Pulleyblank 1963:216, Maung Wun 1975:88)

uy $>$ we (Nishida 1955: 28-9, Pulleyblank 1963:217)

uiw > ui (Pulleyblank 1963:217, Maung Wun 1975:88, Yanson 2006:112)

However, Gong overlooks one important development from Old Burmese to Written Burmese:

o > wa (Nishida 1956:30-3, Maung Wun 1975:89, Dempsey 2001:222-223)

As a consequence of neglecting this change, Gong omits the vowel -o- from his presentation of the internally reconstructed Burmese vowel system with which his paper opens (1980/2002:4-6). ${ }^{7}$

In the comparisons given below, I endeavor to use Old Burmese rather than Written Burmese. Because Old Burmese is not philologically well trodden and has a limited corpus, frequently an Old Burmese attestation of a word in Written Burmese is (currently) unavailable. In such cases, I reconstruct the Old Burmese equivalent of a Written Burmese form by reversing the aforementioned sound changes. ${ }^{8}$

Gong also employed two sound changes from proto-Burmish to Old Burmese $(1980 / 2002: 4){ }^{9}$

Shafer's law: *-ik, *-in > -ac, -añ (Shafer 1940:311, 1941:20-21)

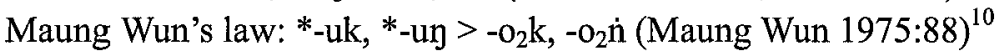

I also make use of these changes. In order to distinguish reconstructions of Old Burmese from Written Burmese and reconstructions of proto-Burmish arrived at using these two sound laws, I use one star for the former and two stars for the latter, thus thweh < *thuyh "spittle" (cf. mrwe < mruy "snake") and mañ $<* *$ min "name".

"Written Tibetan" as used in Sino-Tibetan linguistics refers to forms "gleaned at random from dictionaries and taken at face value" (Chang 1973:336), the premiere choice of dictionary for this end being Jäschke (1882); this work incorporates

7 For further reflections on the evolution of the Burmese vowel system see Hill (2012).

8 The list of vocalic changes given here includes no mergers, so for the purposes of comparing the vowels to other languages there is no danger in reconstructing Old Burmese forms from Written Burmese forms using these changes. Old Burmese does not mark tones, I transfer the tone of a Written Burmese form onto an attested or reconstructed Old Burmese equivalent.

${ }^{9}$ Gong does not name these sound changes after their discoverers as I have.

${ }^{10}$ Because the o that results from Maung Wun's law does not undergo the attested change $o>$ wa, it is necessary to posit these as two distinct vowels $\left(\mathrm{o}_{1}\right.$ and $\left.\mathrm{o}_{2}\right)$ in the synchronic phonology of early Old Burmese (cf. Hill 2012:67-68). 
vocabulary from the few Tibetan texts published in its author's day, previously lexicographical works, and dialect forms from around the Tibetan speaking area. Jäschke himself meticulously notes his authorities, but there has been a tendency to disregard this information (e.g. Matisoff 2003, cf. Hill 2009:178-179). "Old Tibetan" refers to the language of Imperial Tibetan stone inscriptions (cf. Kazushi et al. 2009) and Dunhuang documents (cf. Imaeda et al. 2007); texts from both sources date to before $1006 \mathrm{CE}$. The difference between Old Tibetan and Written Tibetan is smaller than that between Old Burmese and Written Burmese. Only two systematic changes occur between these two phases of Tibetan: sts- merges with s- and my- depalatalizes to $\mathrm{m}$ - before the vowels -i- and -e-. I cite old Tibetan forms whenever a Written Tibetan word could have been affected by these two changes.

In places I provide reconstructed forms of Tibetan; this reveals the Tibetan words to be more like the other two languages than a cursory glance reveals. Hill (2011b) provides evidence for the following changes:

Houghton's law: $*^{\mathbf{j}}>\tilde{\mathbf{n}}$ (Houghton 1898:52, Hill 2011b:444-445)

Laufer's law: *wa > o (Laufer 1898-1899:III-224, Hill 2011b:451)

Simon's law: *mr > br (Simon 1929:187, 197 §86, Hill 2011b:448)

Conrady's law: $* \mathrm{hC}>\mathrm{htC}$, where $\mathrm{C}$ is any fricative or liquid (Conrady 1896:59, Li 1933:149, Hill 2011b:446) ${ }^{11}$

Benedict's law: * j > ź (Benedict 1939:215, Hill 2011b:445)

Li's law: *rj > rgy (Li 1959:59, Hill 2011b:447)

Bodman's law: *ml > md (Bodman 1980:170, Hill 2011b:450).

To these I add two additional changes.

Schiefner's law: *dz > z (Schiefner 1852:364).

Dempsey's law: *-en, *-ek > -in, -ig (Dempsey 2003:90, Hill 2012:72-73)

With these preliminaries on the pre-history of Burmese and Tibetan in place, the examination of the correspondences among the three languages may proceed. The six vowels of Old Chinese present a convenient organizing principle for the presentation of the cognate sets.

${ }^{11}$ I have previously referred to Conrady's law as as "Li's first law", but subsequently discovered that Conrady took this sound change for granted without arguing for it (cf. Conrady 1896:59). Rather than crediting two laws to $\mathrm{Li}$ (as in Hill 2011:446-447), it is more elegant to amend "Li's first law" to "Conrady's law" and "Li's second law" to simply "Li's law". 


\section{Old Chinese *a}

In general Old Chinese *a corresponds directly to Tibetan -a- and Burmese -a-; all three languages continue the original vowel of the proto-language. Examples of this correspondence are numerous enough to present in Appendix 1. There are however a limited number of words in which Tibetan has -e- rather than -a- (cf. Table 1).

Table 1: The correspondence of Old Chinese -a- to Tibetan -e-

\begin{tabular}{|c|c|c|c|c|c|c|}
\hline & Chinese & meaning & Tibetan & meaning & Burmese & meaning \\
\hline 1 & $\begin{array}{l}\text { 慙 } d z a m<*[\mathrm{dz}]^{\text {Sam }} \\
(0611 \mathrm{c})\end{array}$ & ashamed & hdzem & $\begin{array}{l}\text { feel } \\
\text { ashamed }\end{array}$ & - & - \\
\hline 2 & 移 $y e<{ }^{*} 1 a j(0003 q)$ & move (v.) & rje & exchange & lai & $\begin{array}{l}\text { change, } \\
\text { exchange }\end{array}$ \\
\hline 3 & $\begin{array}{l}\text { 產 srean } X<* s-\eta r a r ? \\
(0194 \mathrm{a})^{12}\end{array}$ & $\begin{array}{l}\text { bear (v.), } \\
\text { produce }\end{array}$ & Vsrel & $\begin{array}{l}\text { rear, bring } \\
\text { up }\end{array}$ & - & - \\
\hline
\end{tabular}

These words do not present parallel phonetic environments; the irregular outcome of -e- in Tibetan is therefore difficult to account for as phonetically conditioned. These words must either be rejected as cognates or explained within the context of Tibetan historical phonology (cf. §11).

Matisoff's suggestion that Tibetan underwent the change *-aj $>$-e presents the comparison of Chinese 移 ye<*1aj (0003q) “move (v.)", Tibetan rje "exchange", and Burmese lai "change, exchange" (\#2) as regular (2003:202, 205). However, if Tibetan changed *aj to $\mathrm{e}$, the correspondences in Table 2, showing a correspondence of Chinese *-aj to Tibetan -a, must be rejected. ${ }^{13}$

12 The comparison of the initials looks more plausible with Schuessler's reconstruction *sr'an? / sr en? (2009:291).

${ }^{13}$ Since Tibetan generally merges *ə and *a (cf. $\left.\$ 6\right)$, if *aj $>$ e, one would also expect $*_{\partial j}>$ e. Although there is evidence for such a change, there is also counter evidence, in particular the comparison of Chinese 幾 $k j i j X<* k$ j ? (0547a) "few; how many" and Tibetan hgah "some", cf. $\S 6$. 
Table 2: The correspondence of Old Chinese -aj- to Tibetan -a-

\begin{tabular}{|c|c|c|c|c|c|c|}
\hline & Chinese & meaning & Tibetan & meaning & Burmese & meaning \\
\hline 4 & $\begin{array}{l}\text { 河 } h a<{ }^{*} \mathrm{C} .[\mathrm{g}]^{\mathrm{s}} \mathrm{aj} \\
(0001 \mathrm{~g})\end{array}$ & river & rgal & cross, ford & - & - \\
\hline 5 & $\begin{array}{l}\text { 加 kae<* } \mathrm{k}^{\varsigma} \mathrm{raj} \\
(0015 \mathrm{a})\end{array}$ & add & khral & $\operatorname{tax}$ & - & - \\
\hline 6 & $\begin{array}{l}\text { 罷疲 } b j e<*[\mathrm{~b}] \mathrm{raj} \\
(0026 \mathrm{a}, 0025 \mathrm{~d})\end{array}$ & fatigue & brgyal<*brjal & $\begin{array}{l}\text { sink down, } \\
\text { faint }\end{array}$ & - & - \\
\hline 7 & $\begin{array}{l}\text { 荷 } h a<*[\mathrm{~g}]^{\top} \mathrm{aj} \\
(0001 \mathrm{o})\end{array}$ & carry & khal & burden, load & $k a$ & saddle-frame \\
\hline 8 & $\begin{array}{l}\text { 披 } p h j e<{ }^{*} \mathrm{p}^{\mathrm{h}}(\mathrm{r}) \mathrm{aj} \\
(0025 \mathrm{j})\end{array}$ & divide & hphral & $\begin{array}{l}\text { be separate, } \\
\text { to part }\end{array}$ & prāạh & $\begin{array}{l}\text { be divided } \\
\text { into parts }\end{array}$ \\
\hline 9 & 襍 $l j e<{ }^{\#}$ raj $(0023 \mathrm{~g})$ & hedge & $r a$ & courtyard & - & - \\
\hline 10 & 羅 $l a<{ }^{*} \mathrm{r}^{\mathrm{S}} \mathrm{aj}(0006 \mathrm{a})$ & $\begin{array}{l}\text { a kind of } \\
\text { net }\end{array}$ & $d r a$ & net & - & - \\
\hline $11 ;$ & 波 $p a<^{\#} p^{\mathrm{c} a j}(00251)$ & wave & $d b a h$ & wave & - & - \\
\hline 12 & $\mid \begin{array}{l}\text { 偽 ngjweH }<* \mathrm{~N}-\mathrm{G}^{\mathrm{w}} \text { ajs } \\
(0027 \mathrm{k})\end{array}$ & $\begin{array}{l}\text { false, } \\
\text { cheat }\end{array}$ & rnod<* rńwat & deceive & - & - \\
\hline
\end{tabular}

If one entertains Matisoff's proposed change *aj $>$ e, the suggestion that Old Chinese $*_{-j}$ originates both from inherited ${ }_{-j} j$ (where Tibetan has $-e$ ) and inherited $*_{-1}$ (where Tibetan has -al) would cut down the number of exceptional words from nine to four. This proposal would be particularly compelling if Tibetan $-r$ and -1 corresponded regularly to $-\mathrm{r}$ and $-\mathrm{j}$ in Chinese, but the situation is far more complex, too complex to explore here.

Rather than suggesting *aj > e in Tibetan to account for Chinese 移 ye $<$ laj (0003q) corresponding to Tibetan rje, another option is to simply reject that these two words are cognates. Bodman takes this course; he instead compares Chinese 易 yek< *lek "change; exchange" (0850a) to Tibetan rje "exchange" (1980:127). Although this suggestion may improve the vowel correspondence (it is hard to tell, cf. §5), it introduces a potential irregularity in the codas. ${ }^{14}$

\footnotetext{
${ }^{14}$ For Bodman the correspondence of Chinese $-\mathrm{k}$ with Tibetan open syllables is not irregular, $\mathrm{cf}$. footnote 21 .
} 


\section{Old Chinese *i}

Old Chinese -i- regularly corresponds with Tibetan -i-; Burmese changed - $\mathrm{i}-$ to $-\mathrm{a}-$ before velars (Shafer's law), but otherwise has -i- (cf. Table 3). The irregularity of the -u- vowel in Tibetan gź $u$ * glju "bow", when paired with Burmese liy "bow" leads Matisoff to write that he "often wished that this WT [Written Tibetan] form were gźi" (2003:192). A perusal of an Old Tibetan version of the Răma story, in which the word is consistently spelled gźi, fulfils Matisoff's wish.

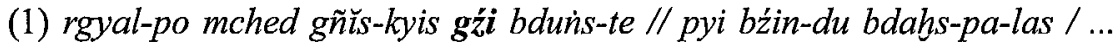
pyogs bcur tshol-źin hgro hgro-ba-las // dub che-ste / nal-so-źin gźz̆-la skom tshugs bchas-pa-las / gñid-log-nas / dbyar dan-po skyes-pa-h̆̌ rtswa gżi-la khris-pa snar zug-pa-dań sad-de //

The two royal brothers drew their bows and set off in pursuit ... They went looking in the ten directions, and had great fatigue. They rested their chins on their bows and fell asleep. In spring, when the newly sprouted grass and wound up their bows and poked into their noses, they awoke. (I.O.L. Tib J 0737/1 11. 166-168, cf. de Jong 1989:115). ${ }^{15}$

Table 3: Correspondences to Old Chinese $*_{i}$ in Tibetan and Burmese

\begin{tabular}{|c|c|c|c|c|c|c|}
\hline & Chinese & meaning & Tibetan & meaning & Burmese & meaning \\
\hline 13 & $\begin{array}{l}\text { 二 } n y i j H<* \text { ni }[\mathrm{j}] \mathrm{s} \\
(0564 \mathrm{a})\end{array}$ & two & $g \tilde{n} i s$ & two & $\begin{array}{l}\text { nhac } \\
<* * \text { nhik }\end{array}$ & two \\
\hline 14 & 死 sijX<*sij? (0558a) & die & $\sqrt{s} \mathrm{~s}$ & die & siy & die \\
\hline 15 & $\begin{array}{l}\text { 四 } s i j H<* \text { s.li[j]s } \\
(0518 \mathrm{a})\end{array}$ & four & $b z ́ i<* b l i \mathrm{i}$ & four & liy & four \\
\hline 16 & 暞 $b j i j<*[\mathrm{~b}] \mathrm{ij}\left(0566 \mathrm{~h}^{\prime}\right)$ & $\begin{array}{l}\text { panther, } \\
\text { leopard }\end{array}$ & $d b y i$ & $\operatorname{lyn} x$ & - & - \\
\hline 17 & 䯠 pjij $X<{ }^{\#} \mathrm{pij}$ ? (0874f) & $\begin{array}{l}\text { femur, } \\
\text { haunch }\end{array}$ & $d p y i$ & hip & - & - \\
\hline
\end{tabular}

${ }^{15}$ In citing Dunhuang documents "I.O.L. Tib J" is one of the shelf number categories for the collection of the British Library and "PT" a shelf number category for the collection of the Bibliothèque nationale de France.

${ }^{16}$ The originally velar final of the Burmese does not match the open syllable of the Chinese and Tibetan. 
Table 3 (cont.): Correspondences to Old Chinese $*_{i}$ in Tibetan and Burmese

\begin{tabular}{|c|c|c|c|c|c|c|}
\hline & Chinese & meaning & Tibetan & meaning & Burmese & meaning \\
\hline 18 & $\begin{array}{l}\text { 妣 } p j i j X<* \text { pij?s } \\
(0566 \mathrm{n})\end{array}$ & $\begin{array}{l}\text { deceased } \\
\text { mother }\end{array}$ & phyi-mo & grandmother & phiy & grandmother \\
\hline 19 & $\begin{array}{l}\text { 矢 syijX<*1i[j]? } \\
(0560 \mathrm{a})\end{array}$ & arrow & 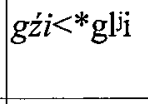 & bow (n.) & liy & bow (n.) \\
\hline 20 & 氏 $t e j X<*^{\prime} \varsigma_{1 j}$ ? $(0590 \mathrm{a})$ & bottom & mthil & bottom, base & - & - \\
\hline 21 & $\begin{array}{l}\text { 屎 syijX<* } \mathrm{q}^{\mathrm{h}} \mathrm{ij} \text { ? } \\
(0561 \mathrm{~d})^{17}\end{array}$ & excrement & $l c i<* \mathrm{hglj}_{\mathrm{o}} \mathrm{ji}$ & dung & khliy & dung \\
\hline 22 & $\begin{array}{l}\text { 界 pjijjH<*pi[k]s } \\
(0521 \mathrm{a})^{18}\end{array}$ & give & sbyin & give & piy & give \\
\hline 23 & 節 $t$ tset<*ts'ik $(0399 \mathrm{e})$ & $\begin{array}{l}\text { joint of } \\
\text { bamboo }\end{array}$ & tshigs & joint & $\begin{array}{l}\text { chac } \\
<* * \text { chik }\end{array}$ & joint \\
\hline 24 & 蟲 srit<**sri[t] (0506a) & louse & sig & louse & - & - \\
\hline 25 & $\begin{array}{l}\text { 縊 ' } e j H<{ }^{*} \mathrm{q}^{\mathrm{g}}[\mathrm{i}] \mathrm{ks} \\
(0849 \mathrm{~g})^{19}\end{array}$ & strangle & hkhyig $^{20}$ & $\begin{array}{l}\text { tie, fasten, } \\
\text { suffocate }\end{array}$ & $a c<* * i k$ & $\begin{array}{l}\text { squeeze, } \\
\text { throttle }\end{array}$ \\
\hline 26 & $\begin{array}{l}\text { 日 nyit<*C.ni[t] } \\
(0404 a)^{21}\end{array}$ & sun & $\tilde{n} i-m a$ & sun & niy & sun \\
\hline 27 & $\begin{array}{l}\text { 脊 } \text { tshit }<*\left[\mathrm{ts}^{\mathrm{h}}\right] \mathrm{i}[\mathrm{t}] \\
(0401 \mathrm{a})^{22}\end{array}$ & varnish & $t \operatorname{sh} i$ & sticky matter & $c e h<*$ ciyh & $\begin{array}{l}\text { be sticky, } \\
\text { adhesive }\end{array}$ \\
\hline 28 & 憐 len<*k.rin (03871) & love; pity & $\operatorname{drin}^{23}$ & kindness & $\begin{array}{l}\text { raññh } \\
<* * \text { rin }\end{array}$ & love \\
\hline
\end{tabular}

${ }^{17}$ The correspondence of the initials looks more plausible in Schuessler's reconstruction *lij? (2009:280).

${ }^{18}$ The codas do not match in any two of the three languages. However, since the vowel correspondence is regular the comparison is suitable for the present purposes.

${ }^{19}$ An alternative possible cognate 結 $k e t<{ }^{\mathrm{k}_{\mathrm{i}}}[\mathrm{t}]$ (0393p) “tie, knot" suffers the disadvantage that it would predict a Burmese velar rather than glottal initial.

${ }^{20}$ Gong omits the Tibetan member of the comparison (1995/2002:112).

${ }^{21}$ The reconstruction $日{ }^{*}$ C.nik is also possible. According to Bodman (1980:127) an Old Chinese $-k$ regularly corresponds to Tibetan open syllables. Alternatively, I propose that Old Chinese $-\mathrm{k}$ corresponds in some cases to Old Tibetan $-\mathrm{h}[-\mathrm{x}]$ (Hill 2011b:453). Because $-\mathrm{b}$ never occurs after the vowel -i- in Old Tibetan (Hill 2005:115-118), one might speculate that Tibetan originally had *ñih "sun".

${ }^{22}$ The final $-t$ in the Chinese is irregular.

${ }^{23}$ The Tibetan is irregular; one would expect a final -n. 
Table 3 (cont.): Correspondences to Old Chinese $*_{i}$ in Tibetan and Burmese

\begin{tabular}{|c|c|c|c|c|c|c|}
\hline & Chinese & meaning & Tibetan & meaning & Burmese & meaning \\
\hline 29 & $\begin{array}{l}\text { 年 } n e n<* C . n^{\mathrm{s}} \mathrm{i}[\mathrm{n}] \\
(0364 \mathrm{a})\end{array}$ & $\begin{array}{l}\text { harvest; } \\
\text { year }\end{array}$ & na-nin & last year & $\begin{array}{l}a n h a c^{24} \\
<* * \text { anhik }\end{array}$ & year \\
\hline 30 & 新 $\sin <* \operatorname{si}[n](0382 n)^{25}$ & firewood & $\sin$ & tree & $\begin{array}{l}s a c \\
<* * \text { sik }\end{array}$ & tree \\
\hline 31 & 仁 nyin<*ni[n] (0388f) & kindness & sñin & heart & $\begin{array}{l}\text { nhac } \\
<* * \text { nhik }\end{array}$ & heart \\
\hline 32 & 田 den<*1sin (0362a) & field & $z i \dot{i n}<* \mid$ lij & field & $\operatorname{lay} y^{26}$ & field \\
\hline 33 & $\begin{array}{l}\text { 新 } \sin <* \text { C.si }[\mathrm{n}] \\
(0382 \mathrm{k})\end{array}$ & new & - & - & $\begin{array}{l}\operatorname{sac} \\
<* * \text { sik }\end{array}$ & new \\
\hline 34 & $\begin{array}{l}\text { 髕 bjin } X<^{*} \text { bin? } \\
(0389 q)\end{array}$ & kneecap & byin & $\begin{array}{l}\text { calf of the } \\
\text { leg }\end{array}$ & - & - \\
\hline 35 & \begin{tabular}{|l} 
盡 $d z i n X$ \\
$<{ }^{*} \mathrm{Cə} \cdot[\mathrm{dz}] \mathrm{i}[\mathrm{n}]$ ? (0381a)
\end{tabular} & exhaust (v.) & $z i n<*$ dzin & be consumed & - & - \\
\hline 36 & $\begin{array}{l}\text { 髕 bjinX<" bin? } \\
(0389 q)\end{array}$ & kneecap & byin & $\begin{array}{l}\text { calf of the } \\
\text { leg }\end{array}$ & - & - \\
\hline 37 & 辛 $\sin <*[\mathrm{~s}] \mathrm{i}[\mathrm{n}](0382 \mathrm{a})$ & $\begin{array}{l}\text { pungent; } \\
\text { painful }\end{array}$ & $\begin{array}{l}\text { mchin } \\
<* \text { m-śsin }\end{array}$ & liver & $\begin{array}{l}\text { sañ ñhh } \\
<* * \operatorname{sinhh}\end{array}$ & liver \\
\hline
\end{tabular}

\footnotetext{
${ }^{24}$ The correspondence of Chinese *-in or Tibetan -in to Burmese -ac $<* *$ ik occurs in enough examples that it cannot be properly called an irregularity (cf. correspondences $29,30,31,33$ ). This correspondence requires further clarification. Hill writes that it "is noteworthy that Burmese does not have the rime añ corresponding to $\mathrm{OC}$ in but only to $\mathrm{OC}$ en. Perhaps the distinction between e and $i$ in Old Chinese provides a conditioning environment to account for the two divergent correspondences of Burmese, namely ac and añ to WrT iń. This hypothesis suggests the sound changes *en $>$ añ, *in $>$ ac" (2012:74). However, two cognates sets potentially contradict this observation, viz. Chinese 憐 len $<$ *k.r rin (0387l) "love; pity" compared to Burmese raññh "love" (\#27) and Chinese 辛 $\sin <* \sin (0382 a)$ "pungent; painful" compared to Burmese saññ "liver" (\#36).

${ }^{25}$ It should be kept in mind throughout that ${ }^{*}-\mathrm{i}[\mathrm{t}]$ and ${ }^{*} \mathrm{i}[\mathrm{n}]$ in the system of Baxter and Sagart allow for ${ }^{*}$-ik and *in as alternative reconstructions (cf. $\# 39,40,41$ ).

${ }^{26}$ The Burmese is irregular and perhaps should be excluded as a potential cognate.

${ }^{27}$ The change of * $\mathrm{m}$-ś- $>$ mch- may be seen as a form of Conrady's law (cf. Hill 2011b: 446447). However, Conrady's law was formulated only with regard to the effects of h-. Another instance of Conrady's law with $\mathrm{m}$ - is suggested by the reconstruction * $\mathrm{m}$-swa for $m$ tsho "lake" (cf. Beckwith 2008:179 footnote 59, Jacques and Michaud 2011: appendix page 11).
} 
Table 3 (cont.): Correspondences to Old Chinese $*_{i}$ in Tibetan and Burmese

\begin{tabular}{|c|c|c|c|c|c|c|}
\hline & Chinese & meaning & Tibetan & meaning & Burmese & meaning \\
\hline 38 & $\begin{array}{l}\text { 吉 } k j i t<* \text { C.qi }[\mathrm{t}] \\
(0393 \mathrm{a})\end{array}$ & luck & skyid & happy & $k_{h y a t^{28}}$ & love \\
\hline 39 & $\begin{array}{l}\text { 切 tshet }<*\left[\mathrm{ts}^{\mathrm{h}}\right]^{\mathrm{si}[\mathrm{t}]} \\
(0400 \mathrm{f})\end{array}$ & cut; urgent & - & - & $\begin{array}{l}\text { chac } \\
<* * \text { chik }\end{array}$ & cut \\
\hline 40 & $\begin{array}{l}\text { 七tshik }<*\left[\mathrm{ts}^{\mathrm{h}}\right] \mathrm{i}[\mathrm{t}] \\
(0400 \mathrm{a})^{29}\end{array}$ & seven & - & - & $\begin{array}{l}k h u-n a c \\
<* * \text { khu- } \\
\text { nik }\end{array}$ & seven \\
\hline 41 & 一 'jit<* Pi[t] (0394a) & one & - & - & $a c<* * \mathrm{ik}$ & a unit, one \\
\hline 42 & $\begin{array}{l}\text { 蒋 } \text { tshim } X<*\left[\mathrm{ts}^{\mathrm{h}}\right][\mathrm{i}] \mathrm{m} \text { ? } \\
(0661 \mathrm{f})\end{array}$ & sleep & $\begin{array}{l}\text { gzim } \\
<* \text { gdzim }\end{array}$ & sleep & - & - \\
\hline 43 & $\begin{array}{l}\text { 浸 } t \text { sim } H<{ }^{\#} \text { tsims } \\
(0661 \mathrm{~m})\end{array}$ & soak & - & - & cim & soak \\
\hline 44 & $\begin{array}{l}\text { 禀 } \lim X<* \text { p.rim? } \\
(0668 \mathrm{a})\end{array}$ & rations & hbrim & distribute & - & - \\
\hline
\end{tabular}

\section{Old Chinese *e}

Old Chinese *e corresponds to $-\mathrm{i}-$, $-\mathrm{a}-$, and $-\mathrm{e}-$ in Tibetan. These three correspondences are however nearly in complementary distribution. In Tibetan -aappears before dentals, -i- before velars (Dempsey's law), and -e- before labials (cf. Table 4). At first glance Burmese offers -a- corresponding to Chinese *-e- in all words except lip-prā "butterfly", but according to Shafer's law the original vowel before velars was *-i-. Thus, Burmese has two correspondences, with -a- before dentals and *-i- before velars and labials. Formulated in this way the exceptional status of lip-prā "butterfly" disappears. Because the two Burmese reflexes -a- and - $\mathrm{i}-$ are in complementary distribution, one may postulate that the Chinese value of the vowel is original with Burmese showing a conditioned sound change.

Not cognizant of the comparisons with dental codas, Hill $(2012: 71-72,74)$ suggests that Tibeto-Burman *-e- unconditionally had changed into *-i- already by the stage of proto-Burmish. To incorporate these new data into the history of the Burmese vowel one may suggest the change $*_{\text {-et }}>$-at occurred before the change $*_{\text {-e- }}>$-i-

${ }^{28}$ The Old Burmese points to a vowel -a- rather than -i-.

${ }^{29}$ The comparison of the initials looks less implausible with Schuessler's reconstruction *snit (2009:302, §29-31). 
内藤丘

Nathan W. Hill

Thus, a series of three successive sound changes accounts for the Burmese forms: *et $>$ at, ${ }^{*} \mathrm{e}>*_{\mathrm{i}}, *_{\mathrm{ik}}>$ ac (Shafer's law).

Table 4: Correspondences to Old Chinese *e in Tibetan and Burmese

\begin{tabular}{|c|c|c|c|c|c|c|}
\hline & \multicolumn{6}{|c|}{ Dental codas } \\
\hline & Chinese & meaning & Tibetan & meaning & Burmese & meaning \\
\hline 45 & $\begin{array}{l}八 \text { peat<* p pret } \\
(0281 \mathrm{a})\end{array}$ & eight & brgyad<*brjad & eight & $\begin{array}{l}\text { rhac } \\
<* \text { rhyat }^{30}\end{array}$ & eight \\
\hline 46 & $\begin{array}{l}\text { 別 bjet<*N-pret } \\
(0292 a)^{31}\end{array}$ & $\begin{array}{l}\text { divide, } \\
\text { separate }\end{array}$ & Vrad & scratch (v.) & prat & $\begin{array}{l}\text { be cut in } \\
\text { two, cut off }\end{array}$ \\
\hline 47 & $\begin{array}{l}\text { 展 trjen } X<* \text { tren? } \\
(0201 \mathrm{a})\end{array}$ & $\begin{array}{l}\text { roll over; } \\
\text { unfold }\end{array}$ & rdal & $\begin{array}{l}\text { spread, } \\
\text { extend }\end{array}$ & - & - \\
\hline 48 & $\begin{array}{l}\text { 偏 phjien<* } \mathrm{p}^{\mathrm{h}} \mathrm{e}[\mathrm{n}] \\
(0246 \mathrm{~h})^{32}\end{array}$ & oblique & phal & $\begin{array}{l}\text { step aside, } \\
\text { make way }\end{array}$ & phay & $\begin{array}{l}\text { go aside, } \\
\text { put aside }\end{array}$ \\
\hline 49 & $\begin{array}{l}\text { 繕 dzyenH } \\
<*[\mathrm{~g}] \mathrm{e}[\mathrm{n}] \text { ?s }(0205 f)\end{array}$ & repair & glan & $\begin{array}{l}\text { patch, } \\
\text { mend (v.) }\end{array}$ & lhan & a patch \\
\hline 50 & $\begin{array}{l}\text { 鮮 sjen<* }[\mathrm{s}][\mathrm{e}] \mathrm{r} \\
(0209 \mathrm{a})\end{array}$ & fresh & gsar & new & $s a$ & titivate \\
\hline \multicolumn{7}{|c|}{ Velar codas } \\
\hline & Chinese & meaning & Tibetan & meaning & Burmese & meaning \\
\hline 51 & $\begin{array}{l}\text { 隻 tsyek<*tek } \\
(1260 \mathrm{c})\end{array}$ & one & gcig $<*$ gceg & one & $\operatorname{tac}<* *$ tik & one \\
\hline 52 & 滴 $t e k<^{\#} \mathrm{t}^{\varsigma} \mathrm{ek}(0877-)$ & $\begin{array}{l}\text { a drop, to } \\
\text { drop }\end{array}$ & thig $<*$ teg & drop, dot & - & - \\
\hline 53 & $\begin{array}{l}\text { 名 mjieng<*C.men } \\
(0826 \mathrm{a})\end{array}$ & name & myin $<*$ myen & name & $\operatorname{mañ} \tilde{n}<* * \min$ & name \\
\hline 54 & $\begin{array}{l}\text { 爭 tsreang }<* \text { m-ts'ren } \\
(0811 \mathrm{a})\end{array}$ & $\begin{array}{l}\text { strife, } \\
\text { quarrel }\end{array}$ & $h d z i n<*$ hdzey & $\begin{array}{l}\text { quarrel, } \\
\text { fight }\end{array}$ & $c a c<* * \mathrm{cik}$ & war, battle \\
\hline
\end{tabular}

${ }^{30}$ The Old Burmese value *rhyat can be inferred both on the basis of Old Burmese spellings such as yhat and het and on cognates in the Loloish and Burmish languages (cf. Nishi 1974:1, 1999:47). The change of Old Burmese -yat to Written -ac is regular, also seen in the words mryat > mrac "root" and khyat $>$ khyac "love". Old Burmese *rhyat is as much a philological interpretation as a reconstruction.

${ }^{31}$ Gong also compares 裂 ljet $<$ " ret (0291f) "split, crack".

${ }^{32}$ Note that $*_{-}[\mathrm{n}]$ in Baxter and Sagart's reconstruction indicates that $-{ }^{*} \mathrm{r}$ is also possible (cf. $\# 62,63,109,110,111,113,114,156,157$ ). 
Table 4 (cont.): Correspondences to Old Chinese *e in Tibetan and Burmese

\begin{tabular}{|c|c|c|c|c|c|c|}
\hline & \multicolumn{6}{|c|}{ Velar codas (cont.) } \\
\hline & Chinese & meaning & Tibetan & meaning & Burmese & meaning \\
\hline 55 & $\begin{array}{l}\text { 井 tsjeng } X<* \text { C.tsen? } \\
(0819 \mathrm{a})\end{array}$ & well (n.) & $r d z i \dot{i}<*$ rdzen & pond & - & - \\
\hline 56 & $\begin{array}{l}\text { 生男 sraeng<* }<\text { s.rey } \\
(0812 \mathrm{~g})\end{array}$ & $\begin{array}{l}\text { sister's } \\
\text { child }\end{array}$ & srin-mo<*sren & $\begin{array}{l}\text { sister of a } \\
\text { man }\end{array}$ & - & - \\
\hline 57 & 盈 yeng<化1en (0815a) & fill & - & - & $\begin{array}{l}\text { plañ } \tilde{P} ? \\
<* * \text { plin? }\end{array}$ & fill \\
\hline 58 & $\begin{array}{l}\text { 冥 } m e n g<{ }^{*} m^{\mathrm{f}} e n \\
(0841 \mathrm{a})\end{array}$ & dark & - & - & $\begin{array}{l}\operatorname{mañn} h \\
<* * \operatorname{minh}\end{array}$ & dark, black \\
\hline \multicolumn{7}{|c|}{ Labial codas } \\
\hline & Chinese & meaning & Tibetan & meaning & Burmese & meaning \\
\hline 59 & 牒 dep< $<^{\#} \Upsilon^{\top} \mathrm{ep}(0633 \mathrm{~g})$ & records & $l e b-m o$ & flat & - & - \\
\hline 60 & 疊 $d e p<<^{\#} 1^{\varsigma} \operatorname{ep~(1255a)~}$ & double & ldeb & $\begin{array}{l}\text { double } \\
\text { down }\end{array}$ & - & - \\
\hline 61 & $\begin{array}{l}\text { 蝴蝶 } h u-d e p \\
<^{\#} \mathrm{~g}^{\mathrm{S} a} \mathrm{a}-1^{\top} \mathrm{ep}(0633 \mathrm{~h})\end{array}$ & butterfly & phye-ma-leb & butterfly & lip-prā & butterfly \\
\hline
\end{tabular}

The overall complementary distribution of Tibetan -a-, -i-, and -e- is broken by five words (cf. Table 5).

Table 5: An exceptional correspondence of Old Chinese *e

\begin{tabular}{|c|c|c|c|c|c|c|}
\hline & Chinese & meaning & Tibetan & meaning & Burmese & meaning \\
\hline 62 & $\begin{array}{l}\text { 徧 penH }{ }^{*}{ }^{*} \mathrm{p} e[\mathrm{n}] \mathrm{s} \\
(0246 \mathrm{~b})\end{array}$ & $\begin{array}{l}\text { (go) all } \\
\text { around }\end{array}$ & Vpel & $\begin{array}{l}\text { increase, } \\
\text { augment }\end{array}$ & - & - \\
\hline 63 & $\begin{array}{l}\text { 霞 } \operatorname{sen} H K^{*}[\mathrm{~s}] \mathrm{e} e[\mathrm{n}] \mathrm{s} \\
(0156 \mathrm{~d})\end{array}$ & sleet & ser & hail & - & - \\
\hline 64 & $\begin{array}{l}\text { 是 } d z y e X<*[\mathrm{~d}] \mathrm{e} \text { ? } \\
(0866 \mathrm{a})\end{array}$ & this & $h d i$ & this & - & - \\
\hline 65 & $\begin{array}{l}\text { 地 } d i j H<*[1]^{\complement} \mathrm{ejs} \\
\left(0004 \mathrm{~b}^{\prime}\right)\end{array}$ & earth, ground & $g z i<{ }^{*} \mathrm{glij}$ & base & mliy & ground \\
\hline 66 & $\begin{array}{l}\text { 摺 tsyep }<{ }^{\#} \text { tep } \\
(0690-)\end{array}$ & to fold & ltab & fold & thap & $\begin{array}{l}\text { place one on } \\
\text { another, repeat }\end{array}$ \\
\hline
\end{tabular}


It would be injudicious to reconstruct additional vowels to account for these examples.

Handel suggests that de "that" rather than hdi "this", is the Tibetan cognate of Chinese 是 dzyeX $<*$ [d]e? (0866a) "this" (2009:301). A correspondence in open syllables of " $\mathrm{e}$ " to "e" is more straightforward than a correspondence of " $\mathrm{e}$ " to " $\mathrm{i}$ ", but the semantics are more straightforward in Gong's formulation. Until further open syllable correspondences are identified it will be difficult to decide whether $h d i$ "this" or de "that" makes the better cognate to 是 dzyeX $<*$ [d]e? (0866a) "this".

The comparison of Chinese 地 to Tibetan gzi $i$ and Burmese mliy (\#65) is the only instance of the Chinese rime *-ejs among the proposed cognate sets considered here. It is conceivable that Tibetan and Burmese underwent a change $*_{e j}>\mathrm{i}$, but without further examples this suggestion is speculation. Bodman reports that 地 has an addition reading ${ }^{*} l^{\text {is }}$ is that would make the correspondence regular (1980:99). Axel Schuessler previously compared 地 $\mathrm{dijH}<*[1]^{\mathrm{c}} \mathrm{ejs}(0004 \mathrm{~b})$ "earth, ground" to Tibetan lder "clay" (1974:196), but appears to have abandoned this comparison (2007:210, 2009:214).

In place of 摺 tsyep < tep (0690-) "fold", Schuessler compares 福 dep $<{ }^{\#} 1^{\text {Iep }}$ $(0690 \mathrm{~g})$ "fold (n.)" (2009:356); this suggestion improves the comparison to Tibetan ltab < *hlab "fold", but essentially abandons the Burmese comparison. Schuessler's additional comparison with Tibetan ldeb "bend, double over" makes the vowel correspondence regular, but one should note that this verb rests on very flimsy lexicographical authority (cf. Hill 2010:160).

\section{Old Chinese *o}

Tibetan and Burmese lack the vowel *ə and Old Chinese - $\partial$ - has complicated correspondences; the Tibetan cognates divide into four categories according to their nuclear vowel: -a-, -o-, -u-, -i-. Nonetheless, the most common correspondence by far is Chinese -ə- versus Tibetan -a- and Burmese -a- (cf. Table 6). This correspondence should be reconstructed as $*^{2}$. 
Table 6: The correspondence of Old Chinese *ə to -a- in Tibetan and Burmese

\begin{tabular}{|c|c|c|c|c|c|c|}
\hline & Chinese & meaning & Tibetan & meaning & Burmese & meaning \\
\hline 67 & $\begin{array}{l}耳 \text { nyiX<*C.nə? } \\
(0981 \mathrm{a})\end{array}$ & ear & rna & ear & $n \bar{a} h$ & ear \\
\hline 68 & $\begin{array}{l}\text { 慈 } d z i<* d z ə \\
(0966 \mathrm{j})^{33}\end{array}$ & kind (adj.) & mdzah & love & $c \bar{a}$ & love \\
\hline 69 & $\begin{array}{l}\text { 子 } t s i X<* \text { tsə? } \\
(0964 \mathrm{a})\end{array}$ & child & tsha & grandchild & - & - \\
\hline 70 & $\begin{array}{l}\text { 母 } m u w X<* m ə ? \\
(0947 \mathrm{a})\end{array}$ & mother & $m a$ & mother & $m a$ & mother \\
\hline 71 & $\begin{array}{l}\text { 事 } d z r i H<* \text { m-s- } \\
\text { roPs (0971a) }\end{array}$ & $\begin{array}{l}\text { serve; service, } \\
\text { affair }\end{array}$ & rdzas & $\begin{array}{l}\text { thing, } \\
\text { matter }\end{array}$ & $c \bar{a}$ & thing \\
\hline 72 & $\begin{array}{l}\text { 友 } h j u w X<*[\mathrm{G}]^{\mathrm{w} ə ?} \\
(0995 \mathrm{e})^{35}\end{array}$ & friend & $\begin{array}{l}\text { grogs } \\
<* \text { g }^{\mathrm{w}} \text { rags }\end{array}$ & friend & - & - \\
\hline 73 & $\begin{array}{l}\text { 賊 } d z o k<* k . d z^{5} ə k \\
(0907 \mathrm{a})\end{array}$ & bandit & $j^{3 g^{36}}$ & robbery & - & - \\
\hline 74 & $\begin{array}{l}\text { 織 tsyik<*tak } \\
(0920 \mathrm{f})\end{array}$ & weave (v.) & hthag & weave (v.) & rak & weave (v.) \\
\hline 75 & 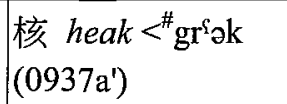 & kernel fruit & rag-tse $e^{37}$ & $\begin{array}{l}\text { stone in } \\
\text { fruits }\end{array}$ & - & - \\
\hline 76 & $\begin{array}{l}\text { 黑 } x o k<* m^{\mathrm{f}} 2 \mathrm{k} \\
(0904 \mathrm{a})^{38}\end{array}$ & black & smag & $\begin{array}{l}\text { dark, } \\
\text { darkness }\end{array}$ & man், mhan் & ink \\
\hline 77 & \begin{tabular}{|l} 
翼 yik<* ${ }^{*}$ Grəp \\
$(0954 \mathrm{~d})^{39}$
\end{tabular} & wing & lag & hand, arm & lak & hand, arm \\
\hline
\end{tabular}

${ }^{33}$ Gong also compares 杽 $d z i H<*$ dzəs $(0966 \mathrm{k})$ "copulate" $(1995 / 2002: 115)$.

${ }^{34}$ The comparison of the initials is not compelling.

${ }^{35}$ The lack of a final $-\mathrm{k}$ in Chinese is an irregularity; however, a correspondence of Chinese -? to Tibetan - $\mathrm{g}$ or Burmese -k is seen elsewhere (cf. \#149, 197).

${ }^{36}$ This word is an exception to Schiefner's law; it should be *hjag or *źag; this exception should perhaps lead to the rejection of the comparison.

${ }^{37}$ Most words in Tibetan that end with -tse are loans from Chinese (cf. e.g. don-tse "copper coin" < 銅子 tóngzi or lcog-tse "table" < 桌子 zhuōzi). These words are probably not cognate.

${ }^{38}$ Gong also compares 墨 $m o k<*$ C.m ${ }^{\text {fak }}(0904 \mathrm{c})$ "ink, black".

${ }^{39}$ The comparison is more compelling with Schuessler's *lok (2009:110). In Baxter and Sagart's reconstruction, comparison with Tibetan hdab-ma "wing" appears more compelling, cf. footnote 45 . 
Table 6 (cont.): The correspondence of Old Chinese *a to -a- in Tibetan and Burmese

\begin{tabular}{|c|c|c|c|c|c|c|}
\hline & Chinese & meaning & Tibetan & meaning & Burmese & meaning \\
\hline 78 & $\begin{array}{l}\text { 夢 mjuwngH } \\
<{ }^{*} \text { C.məns (0902a) }\end{array}$ & dream & rman்-(lam) & dream & $m a k^{40}$ & dream vi \\
\hline 79 & $\begin{array}{l}\text { 鹰 'ing<*[q](r)əy } \\
(0890 \mathrm{e})\end{array}$ & $\begin{array}{l}\text { breast(plate); } \\
\text { oppose }\end{array}$ & bran & breast & rań & breast, chest \\
\hline 80 & $\begin{array}{l}\text { 蠅 ying<*m.rəy } \\
(0892 \mathrm{a})\end{array}$ & fly (n.) & $\mid \begin{array}{l}\text { sbran் } \\
<* \text { smran }\end{array}$ & bee & - & - \\
\hline 81 & 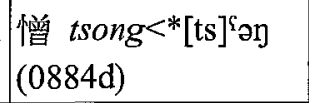 & hate & $s d a \dot{n}$ & hate & - & - \\
\hline 82 & $\begin{array}{l}\text { 蒸 tsying }<* \text { təy } \\
(0896 \mathrm{k})\end{array}$ & $\begin{array}{l}\text { twigs as } \\
\text { firewood }\end{array}$ & - & - & than'h & fuel, firewood \\
\hline 83 & 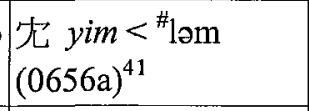 & walk & lam & path & lamh & path $^{42}$ \\
\hline 84 & $\begin{array}{l}\text { 箴鍼 } \\
\text { tsyim<*t.[k]əm } \\
(0671 \mathrm{no})^{43}\end{array}$ & needle & khab & needle & $a p$ & needle \\
\hline 85 & $\begin{array}{l}\text { 柋 nyim } X<* \mathrm{n}[ə] \mathrm{m} ? \\
(0667 \mathrm{q})\end{array}$ & think & sñam & think & - & - \\
\hline 86 & $\begin{array}{l}\text { 立 } l i p<* \text { k.rop } \\
(0694 \mathrm{a})\end{array}$ & stand (v.) & hkhrab & $\begin{array}{l}\text { strike, stamp, } \\
\text { tread heavily }\end{array}$ & ryap & $\begin{array}{l}\text { stand, stop, } \\
\text { halt }\end{array}$ \\
\hline 87 & $\begin{array}{l}\text { 波 kip }<^{\#} \text { kəp } \\
(0681 \mathrm{~h})\end{array}$ & $\begin{array}{l}\text { draw water } \\
\text { from well }\end{array}$ & - & - & khap & $\begin{array}{l}\text { dip up, draw } \\
\text { water from a } \\
\text { well }\end{array}$ \\
\hline 88 & $\begin{array}{l}\text { 答 } t o p<*[t]^{\mathrm{s}}[0] \mathrm{p} \\
(0676 \mathrm{a})^{44}\end{array}$ & answer & $\sqrt{t a b}$ & cast, send & - & - \\
\hline
\end{tabular}

${ }^{40}$ The coda of the Burmese word is irregular.

${ }^{41}$ Gong also compares 由猶 $y u w<*$ lu "follow from" (1079a, 1096r), 道 $d a w X<*^{*} \mathrm{k} ə . \mathrm{l}^{\mathrm{f} u} \mathrm{u}$ "way" (1048a), and 導 dawH < " 1 个us (1048d) "lead", but these comparisons are no longer compelling in the Baxter-Sagart system.

42 Gong also compares Burmese lhamh "to step".

${ }^{43}$ Laurent Sagart draws my attention to the variant character 針 for "needle" (per litteras, 23 October 2009), being part of GSR 686 (the same series as † dzyip "ten" [0686a]), suggests that this word also has the form * $*_{\text {. }}[\mathrm{k}] \mathrm{ep}$, which provides a better fit with the Tibetan and Burmese.

${ }^{44}$ Gong also compares 對 twojH<*[t] $]^{\varsigma}[0]$ ps (0511a) "respond". 
比較脈絡下的古漢語六元音假說

The Six Vowel Hypothesis of Old Chinese in Comparative Context

Table 6 (cont.): The correspondence of Old Chinese *o to -a- in Tibetan and Burmese

\begin{tabular}{|c|c|c|c|c|c|c|}
\hline & Chinese & meaning & Tibetan & meaning & Burmese & meaning \\
\hline 89 & $\begin{array}{l}\text { 泣 khip<*k-rəp } \\
(0694 \mathrm{~h})\end{array}$ & weep & khrab-khrab & $\begin{array}{l}\text { a person prone } \\
\text { to weep }\end{array}$ & - & - \\
\hline 90 & $\begin{array}{l}\text { 習 } z i p<<^{\#} \mathrm{~s}-1 ə p \\
(0690 \mathrm{a})\end{array}$ & $\begin{array}{l}\text { practice, } \\
\text { exercise }\end{array}$ & Vslab & teach, learn & - & - \\
\hline 91 & $\begin{array}{l}\text { 心 } \operatorname{sim}<* \text { səm } \\
(0663 \mathrm{a})\end{array}$ & heart & Vsam & think & - & 一 \\
\hline 92 & $\begin{array}{l}\text { 含 hom } \\
<^{*} \mathrm{C} 2-\mathrm{m}-\mathrm{k}^{\varsigma}[\mathrm{\partial}] \mathrm{m} \\
\left(0651 \mathrm{l}^{\prime}\right)\end{array}$ & $\begin{array}{l}\text { hold in the } \\
\text { mouth }\end{array}$ & hgam & put in the mouth & - & - \\
\hline 93 & $\begin{array}{l}\text { 熊 hjuwng } \\
<^{*} \mathrm{C} .[\mathrm{G}]^{\mathrm{w}}(\mathrm{r}) ə \mathrm{~m} \\
(0674 \mathrm{a})\end{array}$ & bear (n.) & $d^{2 o m}{ }^{45}$ & bear (n.) & wam & bear (n.) \\
\hline 94 & $\begin{array}{l}\text { 焚 bjun <苂an } \\
(0474 \mathrm{a})\end{array}$ & burn & hbar & burn, blaze & $p a$ & shine \\
\hline & $\begin{array}{l}\text { 婚 } x w o n<{ }^{\#} m^{i} \text { ən } \\
(0457 \mathrm{~m})\end{array}$ & marriage & smyan-ka & $\begin{array}{l}\text { marriage, } \\
\text { married couple }\end{array}$ & - & - \\
\hline 96 & $\begin{array}{l}\text { 青 hjwij } H \\
<*[\mathrm{G}]^{\mathrm{w}} \curvearrowright[\mathrm{t}] \mathrm{s}(0523 \mathrm{a})\end{array}$ & stomach & grod $<{ }^{*} \mathrm{~g}^{\mathrm{w}} \mathrm{rad}$ & stomach & - & - \\
\hline & $\begin{array}{l}\text { 幾 } k j i j X<* k ə j ? \\
(0547 a)\end{array}$ & $\begin{array}{l}\text { few; how } \\
\text { many }\end{array}$ & hgah & some & - & - \\
\hline 98 & $\begin{array}{l}\text { 違 } h j w i j<*[\mathrm{G}]^{\mathrm{w}} \partial[\mathrm{j}] \\
(0571 \mathrm{~d})\end{array}$ & go against & hgol<*hgwal & part, deviate & 一 & - \\
\hline & $\begin{array}{l}\text { 歸 } k j w i j<^{*}[\mathrm{k}]^{\mathrm{w}} \partial j \\
(0570 \mathrm{a})^{46}\end{array}$ & return & $\begin{array}{l}\text { hkhor } \\
<* \text { hkh"ar }\end{array}$ & circle & - & - \\
\hline
\end{tabular}

${ }^{45}$ The reconstruction of this word in pre-Tibetan is not easy, but the Chinese and Burmese comparata make clear that some kind of labio-velar is at play, i.e. that the vowel -o- in Tibetan is due to Laufer's law. The initial correspondence seen in the comparision of Tibetan

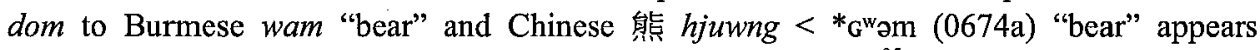
irregular. The Bodish languages offer wam for Kurtöp and wom ${ }^{35}$ for Monpa. This suggests that both Laufer's law and the d- in Tibetan is recent. The comparison of Tibetan hdab-ma “wing" to Chinese 翌/翼 $y i k<*^{*}$ Grop “wing" (0912b, 0954d) exhibits the same correspondence in the initials. The Bodish languages unforutnately do not appear to have this etymon. Tangut also has a d- in "bear" 解 dow.

${ }^{46}$ Gong also compares 回 $h w o j<*[\mathrm{c}]{ }^{\mathrm{w}}$ əj (0542a) "revolve" (1995/2002:85). 
Table 6 (cont.): The correspondence of Old Chinese * ${ }^{*}$ to -a- in Tibetan and Burmese

\begin{tabular}{|c|c|c|c|c|c|c|}
\hline & Chinese & meaning & Tibetan & meaning & Burmese & meaning \\
\hline 100 & $\begin{array}{l}\text { 洗洒 } \operatorname{sej} X<*[s]]^{\varsigma} \text { 'rr? } \\
(0478 \mathrm{j} / 0594 \mathrm{~g})^{47}\end{array}$ & wash & Vstsal & clean, clear & - & - \\
\hline 101 & \begin{tabular}{|l} 
煇輝 $x j w i j<* q^{\text {wh }}$ or \\
$(0458 \mathrm{k} ; 04581)$
\end{tabular} & brilliant & $\begin{array}{l}\text { khrol-khrol } \\
<* \text { khwral }\end{array}$ & $\begin{array}{l}\text { bright, shining, } \\
\text { sparkling, } \\
\text { glistening }\end{array}$ & - & - \\
\hline
\end{tabular}

In three words Tibetan unexpectedly has -o- as the main vowel (cf. Table 7); the Burmese cognates show -a- as expected.

Table 7: The correspondence of Old Chinese *a to - 0 - in Tibetan and -a- in Burmese

\begin{tabular}{|c|c|c|c|c|c|c|}
\hline & Chinese & meaning & Tibetan & meaning & Burmese & meaning \\
\hline 102 & $\begin{array}{l}\text { 息 } s i k<* \text { sok } \\
(0925 \mathrm{a})\end{array}$ & breathe & srog & life & sak & life, breath \\
\hline 103 & $\begin{array}{l}\text { 牧 mjuwk<*mak } \\
(1037 \mathrm{a})\end{array}$ & herdsman & hbrog $<*$ mrog & nomad & - & - \\
\hline 104 & $\begin{array}{l}\text { 彗 zim<* }<2-1[ə] \mathrm{m} \\
(0662 \mathrm{a})\end{array}$ & $\begin{array}{l}\text { measure of } \\
8 \text { chi 尺 }\end{array}$ & $\begin{array}{l}\text { mdom-pa } \\
<* \text { mlom }\end{array}$ & fathom (n.) & lam & fathom (n.) \\
\hline
\end{tabular}

These irregularities are best treated within the context of Tibetan historical phonology; it is neither appropriate to reconstruct an extra vowel in the proto-language, nor to reject these three comparisons out of hand.

Noting that Lashi distinguishes $s o P^{55}$ "breath" and -'sak "life" (cf. Nishi 1999: 105-106), it is likely that Burmese has collapsed two words ("sak > sak "life" and *'sak > sak "life"), and that Tibetan srog "life" and Chinese 息 $s i k<$ *sok (0925a) "breath" are not direct cognates. Gong does not include Tibetan srog in the comparison (1995/2002:113).

Less easy to set aside are the twelve words in which Old Chinese *-2corresponds to -u- in Tibetan or Burmese. The agreement of Tibetan and Burmese suggests that either Chinese has innovated or the reconstruction of *-ə- rather than *$\mathrm{u}$ - for Chinese for these words is mistaken. In certain phonetic circumstances it is

${ }^{47}$ Gong compares Chinese 洗 $s e j X<*[\mathrm{~s}]^{\complement}$ ər? (0478j) "wash" and 酒 $s e j X<*[\mathrm{~s}]^{\text {`ər? }}$ (0594g) separately to Tibetan $V_{s a l}<V_{\text {stsal }}$ "clean, clear" and $V_{b s i l}$ "wash" respectively $(1995 / 2002$ : 87). However, the primary meaning of Tibetan bsil is "cool"; its use as an honorific verb "wash" is probably derivative. In view of the identical pronunciation and meaning of the two Chinese characters Schuessler $(2009: 283,330)$ is surely correct to identify them. 
difficult to distinguish Old Chinese ${ }^{*}$-ə- and $*_{-u-}$-; it is therefore convenient to separately discuss the four relevant rime types of the Chinese reflexes.

Four cognates are available for Old Chinese syllables with the main vowel -əand labial codas (cf. Table 8).

Table 8: Correspondences of Old Chinese -a with labial codas in Tibetan and Burmese

\begin{tabular}{|c|c|c|c|c|c|c|}
\hline & Chinese & meaning & Tibetan & meaning & Burmese & meaning \\
\hline 105 & 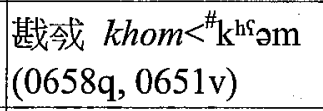 & $\begin{array}{l}\text { vanquish, } \\
\text { kill }\end{array}$ & $\sqrt{ }$ kum & kill & - & - \\
\hline 106 & $\begin{array}{l}\text { 尋 } \operatorname{zim}<* \mathrm{~s} \rho-1[0] \mathrm{m} \\
(0662 \mathrm{a})\end{array}$ & $\begin{array}{l}\text { warm up } \\
\text { (food) }\end{array}$ & gtum & $\begin{array}{l}\text { fierce, hot, } \\
\text { angry }^{48}\end{array}$ & lum & warm \\
\hline 107 & $\begin{array}{l}\text { 娃姙 nyim } H<{ }^{H} \text { nəms } \\
(0667 \mathrm{ik})^{49}\end{array}$ & pregnant & sbrum & pregnant & - & - \\
\hline 108 & $\begin{array}{l}\text { 人 nyip<* } \mathrm{n}[ə] \mathrm{p} \\
(0695 \mathrm{a})\end{array}$ & enter & $n u b$ & to sink, set & $\dot{n} u p$ & $\begin{array}{l}\text { to dive, go } \\
\text { beneath }\end{array}$ \\
\hline
\end{tabular}

Whereas Baxter and Sagart allow for both *u and *ə before labials (represented P) in their reconstruction of Old Chinese, Schuessler makes no attempt to distinction $*_{u P}$ and $*_{\partial} \mathrm{P}$, reconstructing everywhere $*_{\partial \mathrm{P}}(2009: 354,359)$. If one follows Schuessler's approach, a Chinese merger of originally distinct ${ }^{\mathrm{u}} \mathrm{uP}$ and $*_{\partial \mathrm{P}}$ and a reconstruction $* u$ in the proto-language on the strength of the Tibetan or Burmese data accounts for the correspondence of Old Chinese * $\partial \mathrm{P}$ to both $-\mathrm{aP}$ and $-\mathrm{uP}$ in Tibetan.

${ }^{48}$ Gong (1995/2002:119) omits the Tibetan, which Bodman suggests, reconstructing *glum (1980: 539).

${ }^{49}$ Gong (1995/2002:120) reconstructs 娃姙 nyimH <*smrum $(0667 \mathrm{i}, \mathrm{k})$ "pregnant”. No 諧聲 xiéshèng contacts suggest an $\mathrm{m}$ - in the series GSR 667. Gong appears to be following the suggestion of Pulleyblank (1979:36) that based on the transcription 任那 for Mimana (a fifth century polity, which was a member of the Kaya 加耶 federation on the Korean peninsula) that this 諧聲 xiéshēng series once had initial *m-. The evidence for reading 任 那 as Mimana comes from the 日本書紀 Nihonshoki, where in the record of 垂仁 Suinin it is also spelled 彌摩那 (Kojima et al. 1994:295). Sagart argues that 妊妵 nyimH $<* \mathrm{n}[$ ○]m-s "pregnant" $(0667 \mathrm{i}, \mathrm{k})$ is etymologically derived from 任 nyim $<*_{\mathrm{n}}[\mathrm{o}] \mathrm{m}(0667 \mathrm{f})$ "to carry". The semantics are thus not favourable to Gong's suggestion. Sagart also proposes an etymological connection with 南 nom $<{ }^{*} n^{\mathrm{s}}[0] \mathrm{m}$ (0650a) "south", which argues against the m- initial proposed by Pulleyblank (cf. Sagart 1988). Jacques (2003:124) citing Pan (2000: 240-241) instead compares Tibetan sbrum "pregnant" with 孕 ying $<* 1[i] n$-s. I was however mistaken to report that *m.rəm-s is a possible reconstruction of z̧子 $y$ ingH (Hill 2011:449). 
However, because the system of Baxter and Sagart distinguishes *uP and ${ }^{*} \mathrm{P}$, it should be possible to test the hypothesis that these four words had the vowel ${ }^{*} \mathrm{u}$ and not the vowel *ə in Old Chinese. Baxter (1992:550) reconstructs *um for those words which have rhyme contacts in the 詩經 Shijing with *uy. Such evidence exists for six words, only one of which Baxter and Sagart (2011) currently reconstruct with *u.

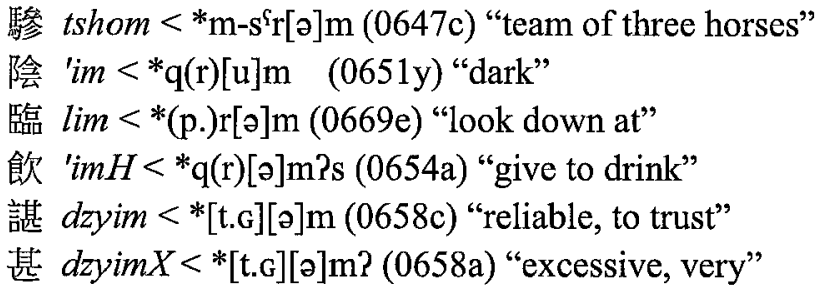

It appears that Baxter and Sagart are now using criteria apart from rhyming with *-uy in the 詩經 Shijjing for reconstructing *u in Old Chinese. Because they have not published any further reflections on this problem, it is necessary here to put the matter aside. Admitting merely the possibility that these four words may have had the rime *uP in Old Chinese, I repeat them below in Table 15. Baxter and Sagart (2011) themselves tentatively suggest an original vowel *u for 尋 zim $<{ }^{*}$ sə-1[ə]m (0662a) "warm up (food)".

In syllables with dental codas and non-labial initials it is easier to distinguish -uand -ə- than in other phonetic environments (cf. Table 9).

Table 9: Correspondences of Old Chinese -a with dental codas and non-labial initials in Tibetan and Burmese

\begin{tabular}{|c|c|c|c|c|c|c|}
\hline & Chinese & meaning & Tibetan & meaning & Burmese & meaning \\
\hline 109 & 塺 drin $<^{*}[\mathrm{~d}] \mathrm{ra}[\mathrm{n}](0374 \mathrm{a})$ & dust (n.) & $r d u l$ & dust, ashes & - & - \\
\hline 110 & 銀 ngin<*yre[n] $(0416 \mathrm{k})$ & silver & dñul & silver & $\dot{n} u y$ & silver \\
\hline 111 & 根 kon $<{ }^{*}[\mathrm{k}]^{\mathrm{T}} \mathrm{\partial}[\mathrm{n}](0416 \mathrm{~b})$ & $\begin{array}{l}\text { root, } \\
\text { trunk }\end{array}$ & khul-ma & $\begin{array}{l}\text { bottom or } \\
\text { side of sth }\end{array}$ & - & - \\
\hline 112 & 䫀 kon $X<^{\#}[\mathrm{k}]^{\mathrm{S}} \mathrm{\partial}[\mathrm{n}]$ ? (0416-) & neck & $m g u l$ & neck $^{50}$ & - & - \\
\hline
\end{tabular}

Because the Middle Chinese readings of these characters lack a medial -w- (i.e. are 開 $\square$ kāikŏu syllables), none of these three words can be reconstructed with *uin Old Chinese (Baxter 1992:427-28). ${ }^{51}$ These words must be rejected as potential

${ }^{50}$ Gong also compares mgur "neck" (1995/2002:103).

${ }^{51}$ Baxter mentions explicitly that 栕 $d r i n<* d r ə n(0374 a)$ has the rime -ən $(1992: 427)$. 
cognates.

The next Chinese phonetic environment to consider is syllables with dental codas and labial initials (cf. Table 10 ). Here ${ }^{*}$-ən and ${ }^{*}$-un are again difficult to distinguish.

Table 10: Correspondences of Old Chinese -a with dental codas and labial initials in Tibetan and Burmese

\begin{tabular}{|l|l|l|l|l|l|l|}
\hline & \multicolumn{1}{|c|}{ Chinese } & meaning & Tibetan & meaning & Burmese & meaning \\
\hline 113 & 偩 bin<*(Cə.)[b]rə[n] (0471v) & poor & $d b u l$ & poor & - & - \\
\hline 114 & 分 pjun<*pə[n] (0471a) & divide & $h b u l, h p h u l$ & give & - & - \\
\hline 115 & 粉 pjunX<*mə.pən? (0471d) & flour & dbur & smooth (v.) & - & - \\
\hline 116 & 飛 pjij <*Cə.pə[r] (0580a) ${ }^{52}$ & fly (v.) & $h p h u r$ & fly (v.) & - & - \\
\hline
\end{tabular}

Without making his reasoning explicit, Baxter (1992:427) identifies 貧 bin <*bren (0471v) as an instance of *-ən; if 貧 has the rime -ən, its comparison with Tibetan $d b u l$ "poor" must be rejected. Again without comment, but presumably based on the rhyming patterns of the 詩經 Shijing, Baxter further remarks that words with phonetic 分 "are generally to be reconstructed" with *-on (1992:431). This suggests that 分 and 粉 do not permit reconstructions with the vowel *u and are not cognate with the Tibetan words $h b u l$ "give" and $d b u r$ "smooth (v.)" respectively.

In 1992 Baxter did not yet recognize $-r$ as a possible final in Old Chinese. Consequently, one must consult his discussion of the rimes *aj and *uj for criteria to differentiate * ${ }^{*}$ and $* u$ in the reconstruction of 飛. The evidence of the 詩經 Shijing does not distinguish *j and *uj after labial initials (Baxter 1992:454), nonetheless Baxter sees some reason to suppose that these rimes were distinct in a period before the composition of the 詩經 Shijjing (1992:458-462). There is currently no obstacle to accepting 飛 as a cognate of Tibetan hphur "fly (v.)", suggesting that it may have been *Co.pur in pre-Shijizing Chinese, and adding it to Table 15.

In sum, among the twelve words which exhibit a correspondence of Chinese *-əto Tibetan -u- seven must be rejected (塵銀根䫀賛分粉, \#109-115) and four may be kept, if they are reconstructed as *-u- in Old Chinese (㦲尋入飛); “pregnant" (娃婎, \#107) should be rejected on other grounds (cf. footnote 49).

In four words Old Chinese *-ə- appears to correspond to Tibetan -i- (cf. Table 11); in the two cases a Burmese comparison is available it confirms -i-.

\footnotetext{
${ }^{52}$ Gong instead compares Tibetan hphur "fly" to 枌朌 pjun <*(Cə.)pə[r] (0471 ef) “fly (v.), soar" and 奮 pjunH<*p[ə][n]s (0473a) "spread wings and fly" (1995/2002:105).
} 
Table 11: The correspondence of Old Chinese -ə- Tibetan -i-

\begin{tabular}{|c|c|c|c|c|c|c|}
\hline & Chinese & meaning & Tibetan & meaning & Burmese & meaning \\
\hline 117 & $\begin{array}{l}\text { 禁 } k i m H<* k r[a] m s \\
(0655 \mathrm{k})\end{array}$ & prohibit & khrims & right, law & - & - \\
\hline 118 & $\begin{array}{l}\text { 沈 drim }<*[1] \mathrm{r}[0] \mathrm{m} \\
(0656 \mathrm{~b})\end{array}$ & $\operatorname{sink}(\mathrm{v})$. & thim & $\begin{array}{l}\text { fade, } \\
\text { dissolve }\end{array}$ & tim & shallow \\
\hline 119 & $\begin{array}{l}\text { 懔 } \lim X<^{\#} \mathrm{r} ə \mathrm{~m} ? \\
(0668 \mathrm{~d})\end{array}$ & $\begin{array}{l}\text { full of fear, } \\
\text { respectful }\end{array}$ & rim-hgro & $\begin{array}{l}\text { honor, } \\
\text { service }^{53}\end{array}$ & - & - \\
\hline 120 & $\begin{array}{l}\text { 擒 } \operatorname{gim}<{ }^{\#}[\mathrm{C} . \mathrm{g}](\mathrm{r})[ə] \mathrm{m} \\
(0651 \mathrm{n})\end{array}$ & catch & sgrim & hold fast & - & - \\
\hline 121 & $\begin{array}{l}\text { 窨 'imH<* } \mathrm{q}(\mathrm{r})[2] \mathrm{ms} \\
(0653-)^{54}\end{array}$ & $\begin{array}{l}\text { subterranean } \\
\text { room }\end{array}$ & khyim & house & im & house \\
\hline 122 & 其 $g i<^{*}$ ge $(0952 a)$ & $\begin{array}{l}(3 p \\
\text { possessive })\end{array}$ & $g y i$, etc. & (genitive) & - & - \\
\hline 123 & 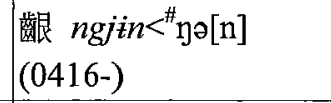 & gums & $\begin{array}{l}\text { rñil / sñil } \\
<*{ }^{\mathrm{j}} \mathrm{il}\end{array}$ & gums & - & - \\
\hline 124 & $\begin{array}{l}\text { 几 } k i j X<* \mathrm{kr} r j \text { ? } \\
(0602 \mathrm{a})\end{array}$ & $\begin{array}{l}\text { stool, small } \\
\text { table }\end{array}$ & $k h r i$ & $\begin{array}{l}\text { emperor, } \\
\text { throne }\end{array}$ & khriy & foot, leg \\
\hline
\end{tabular}

It is difficult to distinguish *-om and *-im in Old Chinese (Baxter 1992:553-555); the possibility should thus be kept in mind that cases of *-əm in Old Chinese should instead be reconstructed *im (\#117-121). The remaining comparisons must be rejected as cognates or explained within the context of Tibetan historical phonology.

In the comparison of 其 " $3 p$ possessive" and gyi, etc. "genitive", the vowel in either language could be explained by the high frequency grammatical nature of the words under comparison. In contrast, the comparison of Chinese 几 "stool, small table" to Tibetan khri "imperial title, throne" (\#124) should be rejected. In Old Tibetan $k h r i$ only ever occurs in conjunction with brtsan as part of an emperor's reign name, e.g. Khri Sron-lde brtsan; it never means "throne". Thus, this comparison faces semantic as well as phonetic obstacles.

In five comparisons Old Chinese -ə- corresponds to Tibetan -e-, and either -a- or i- in Burmese (cf. Table 12)

\footnotetext{
${ }^{53}$ Walter discusses the semantics of this term and many textual passages (2009:166-174), but does not venture an etymology.

${ }^{54}$ Luarent Sagart proposes this comparison (per litteras 20 June 2012).
} 
Table 12: The correspondence of Old Chinese -ə- with Tibetan -e-

\begin{tabular}{|c|c|c|c|c|c|c|}
\hline & Chinese & meaning & Tibetan & meaning & Burmese & meaning \\
\hline 125 & $\begin{array}{l}\text { 繩 zying<*Cə.lən } \\
(0892 b)\end{array}$ & rope, cord & $\mid \begin{array}{l}\text { bbren } \\
<* \text { hmmren }\end{array}$ & braid & amhyan & $\begin{array}{l}\text { string, } \\
\text { thread }\end{array}$ \\
\hline 126 & $\begin{array}{l}\text { 娓 } x j w i j \mathrm{ij} X<*_{\text {mojoj? }} \\
(0583 \mathrm{e})^{55}\end{array}$ & burn & mye & fire & $m \bar{\imath} h$ & fire \\
\hline 127 & $\begin{array}{l}\text { 邇 nyeX }<^{\#} \text { nəj? } \\
(0359 \mathrm{c})\end{array}$ & $\begin{array}{l}\text { near, draw } \\
\text { near to }\end{array}$ & $\tilde{n} e$ & near & $n \bar{\imath} h$ & near \\
\hline 128 & $\begin{array}{l}\text { 尾 } m j i j j X<*[\mathrm{~m}] \text { jj? } \\
(0583 \mathrm{a})\end{array}$ & tail & - & - & $m r i ̄ h$ & tail \\
\hline 129 & $\begin{array}{l}\text { 銑 } \operatorname{sen} X<<^{\#} \operatorname{ser} ? \\
(0478 \mathrm{~h})\end{array}$ & glossy & gser & gold & - & - \\
\hline 130 & $\begin{array}{l}\mid \begin{array}{l}\text { 饉 gin } H<*[\mathrm{~g}] \mathrm{re}[\mathrm{r}] \mathrm{s} \\
(0480 \mathrm{r})^{56}\end{array} \\
\end{array}$ & famine & bkren-po & $\begin{array}{l}\text { beggar, } \\
\text { destitute } \\
\text { person }\end{array}$ & - & - \\
\hline
\end{tabular}

According to Dempsey's law Tibetan changed *-en to -in (cf. Dempsey 2003:90, Hill 2012:72-73), it is thus rather surprising to see the sequence -en in the word bbren "braid". The fact that this Tibetan word participates in Simon's law and the existence of a Naish cognate *briN (Jacques and Michaud 2011: appendix, p. 16) militates against disregarding it as a look-alike or loan. For lack of a better explanation, it is perhaps thinkable that the importance of this word in the myth of Tibet's first emperor Gñah-khri btsan-po, could indicate that it was borrowed along with the story from an early Tibetan dialect which had not undergone $*_{\text {-en }}>$-in into the dialect which formed the basis of the writing system and had undergone this change.

(2) huñ-nas rta rdzĭhi mchid-nas / dbuh hbren zan்-yag kyan gchad-du gsol / dbuh skas sten dguh yan kha thur-du bstan-du gsol-nas / de rnam gñis kyan de bźin gnàn-n்o //

Then, the horse groom requested that the emperor cut his numerous headbraids, and he requested that he also turn down his nine-stepped headladder. The king granted these two requests accordingly. (cf. PT 1287 line 16, cf. Imaeda et al. 2007: 200)

\footnotetext{
${ }^{55}$ Gong also compares Ch. 火 xwaX $<*$ qwh $^{\text {whoj}}$ ? (0353a) "fire" (1995/2002:83), but the initial does not correspond in the Baxter-Sagart system.

${ }^{56}$ The reconstruction *-[r] in Baxter and Sagart's system indicates that *-n is also possible.
} 
內藤丘

Nathan W. Hill

The four remaining comparisons of Old Chinese -*ə- to Tibetan -e- are examples of either * $*_{j}$ or *or in Old Chinese, suggesting that a conditioned sound law is at play. Bringing together from Tables 6 and 12 the comparisons which involve Chinese syllables with the rimes * ${ }^{2}$ or *or results in Table 13.

Table 13: Cognates of the Chinese rimes *aj and *or

\begin{tabular}{|c|c|c|c|c|c|c|}
\hline & Chinese & meaning & Tibetan & meaning & Burmese & meaning \\
\hline 97 & $\begin{array}{l}\text { 幾 } k j i j X<{ }^{*} \mathrm{k} ə \mathrm{j} ? \\
(0547 \mathrm{a})\end{array}$ & $\begin{array}{l}\text { few; how } \\
\text { many }\end{array}$ & hgah & some & - & - \\
\hline 100 & $\begin{array}{l}\text { 洗洒 } \operatorname{sej} X<*[\mathrm{~s}]^{\text {f }} \text { or? } \\
(0478 \mathrm{j} / 0594 \mathrm{~g})\end{array}$ & wash & $\sqrt{\text { stsal }}$ & clean, clear & -57 & - \\
\hline 98 & $\begin{array}{l}\text { 違 } h j w i j<*[\mathrm{G}]^{\mathrm{w}} \mathrm{j}[\mathrm{j}] \\
(0571 \mathrm{~d})\end{array}$ & go against & $\begin{array}{l}\text { hgol } \\
<* \text { hgwal }^{\text {wal }}\end{array}$ & part, deviate & - & - \\
\hline 99 & $\begin{array}{l}\text { 歸 } k j w i j<*[\mathrm{k}]^{\mathrm{w}} ə \mathrm{j} \\
(0570 \mathrm{a})\end{array}$ & return & $\begin{array}{l}h k h o r \\
<* h k^{w} \text { ar }\end{array}$ & circle & - & - \\
\hline 101 & $\begin{array}{l}\text { 煇輝 } x j w i j<* \mathrm{q}^{\text {wh }} \text { or } \\
(0458 \mathrm{k} ; 04581)\end{array}$ & brilliant & $\begin{array}{l}\text { khrol-khrol } \\
<* \mathrm{kh}^{\mathrm{w}} \mathrm{ral}\end{array}$ & $\begin{array}{l}\text { bright, shining, } \\
\text { sparkling, } \\
\text { glistening }\end{array}$ & - & - \\
\hline 126 & $\begin{array}{l}\text { 娓 } x j w i j X<{ }^{*} \operatorname{moj} ? \\
(0583 \mathrm{e})^{58}\end{array}$ & burn & mye & fire & $m \bar{i} h$ & fire \\
\hline 128 & $\begin{array}{l}\text { 尾 } m j i j X<*[\mathrm{~m}] \partial j ? \\
(0583 \mathrm{a})\end{array}$ & tail & - & - & $m r i ̄ h$ & tail \\
\hline 127 & $\begin{array}{l}\text { 雨 } n y e X<^{\#} \text { nəj? } \\
(0359 \mathrm{c})\end{array}$ & $\begin{array}{l}\text { near, draw } \\
\text { near to }\end{array}$ & ñe & near & $n \bar{\imath} h$ & near \\
\hline 129 & $\begin{array}{l}\text { 銑 } \operatorname{sen} X<{ }^{\#} \text { sər? } \\
(0478 \mathrm{~h})\end{array}$ & glossy & gser & gold & - & - \\
\hline 130 & $\begin{array}{l}\text { 饉 } \operatorname{gin} H<*[\mathrm{~g}] \mathrm{r}[\mathrm{r}] \mathrm{s} \\
(0480 \mathrm{r})\end{array}$ & famine & bkren-po & $\begin{array}{l}\text { beggar, } \\
\text { destitute } \\
\text { person }\end{array}$ & & \\
\hline
\end{tabular}

${ }^{57}$ Gong also compared Burmese chiyh "wash", but since both the initial and rime are off, I disregard this suggestion.

${ }^{58}$ Gong also comapres Chinese $火 x w a X<{ }^{*} q^{\text {whr }}$ əj? (0353a) "fire", but the initial does not correspond in the Baxter-Sagart system. 
It is possible to propose that the divergent correspondences of Chinese ${ }^{*}$ jj and * ər in Tibetan are phonetically conditioned. Following Laufer's law, I have reconstructed the Tibetan examples of $-0-$ as ${ }^{*}$ a , but one could potentially reconstruct *we. If this strategy is taken, Tibetan hgah "some" and Vstsal "clean, clear" are the only forms in need of explanation.

Gong gives the Written Tibetan verb $\sqrt{ } \mathrm{sal}$ (pres. gsel, past, bsal, fut. bsal, imp. sol) "cleanse, clear", but the Written Tibetan derive via the change sts- $>$ s- from an Old Tibetan verb with the root is $V_{\text {stsal, as examples such sdig-pa thams-cad bstsald "clear }}$ away all sins" (IOL Tib J 751, f. 40v, 1. 1) and bar-chad thams-cad yons-su bstsalte "completely clear away all hindrances" (PT 16, f. 29r, 1. 2) clearly reveal. The comparison of Chinese s- to Tibetan sts- weighs against the validity of this comparison. Ignoring differences of voicing or prefixes Chinese TS- normally corresponds to Tibetan TS- (e.g. \#54, 55, 68, 69, 154, 182, 185, 191, 275, 280, 314, 321). If we

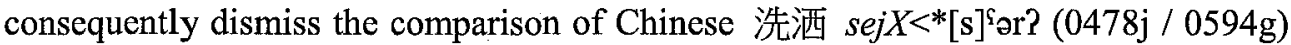
"wash" and Tibetan $\sqrt{s t s a l}$ "cleanse, clear" (\#100) the only hurdle in the way of a regular change $*_{\partial j}>\mathrm{e}$ in Tibetan is the comparison of Chinese 幾 $k j i j \mathrm{j} X<{ }^{*} \mathrm{k} ə \mathrm{j}$ ? (0547a) "few; how many" with Tibetan hgah "some" (\#97).

To contextualize consideration of hgah "some" (\#97) it is necessary to look at Chinese cognates of Tibetan -ah in general (cf. Table 14).

Table 14: Old Chinese correspondences to Tibetan -ah

\begin{tabular}{|c|c|c|c|c|c|c|}
\hline & Chinese & meaning & Tibetan & meaning & Burmese & meaning \\
\hline 97 & \begin{tabular}{|l} 
幾 kjijX $<<* k a j ?$ \\
$(0547 \mathrm{a})$
\end{tabular} & $\begin{array}{l}\text { few; how } \\
\text { many }\end{array}$ & hgah & some & - & - \\
\hline 11 & 波 $\mathrm{pa}<^{\#} \mathrm{p}^{\mathrm{C}}$ aj $(00251)$ & wave & $d b a h$ & wave & - & - \\
\hline 68 & 慈 dzi<*dzə (0966j) & kind (adj.) & mdzah & love & $c \bar{a}$ & love \\
\hline 131 & $\begin{array}{l}\text { 百 paek }<{ }^{*} p^{\varsigma} \text { rak } \\
(0781 a)\end{array}$ & hundred & brgyah<*brjah & hundred & $r y \bar{a}$ & hundred \\
\hline 132 & $\begin{array}{l}\text { 渡 } \mathrm{duH}<^{\#} \mathrm{~d}^{\mathrm{C}} \mathrm{aks} \\
(0801 \mathrm{~b})\end{array}$ & ford & hdah & pass over & - & - \\
\hline 133 & $\begin{array}{l}\text { 射 zyek<*Cə.1Ak } \\
(0807 a)\end{array}$ & $\begin{array}{l}\text { hit with bow } \\
\text { and arrow }\end{array}$ & $m d a h<*$ mlah & arrow & $m l \bar{a}$ & arrow \\
\hline 134 & $\begin{array}{l}\text { 魄 phaek }<* \mathrm{p}^{\mathrm{h}} \mathrm{r} \text { rak } \\
(0782 \mathrm{o})\end{array}$ & soul & brlah & soul & prā & soul \\
\hline 135 & 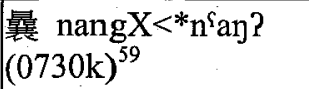 & in past times & gnah-bo & $\begin{array}{l}\text { ancient, in } \\
\text { old time }\end{array}$ & - & - \\
\hline
\end{tabular}

\footnotetext{
${ }^{59}$ The correspondence of the codas is irregular.
} 
内藤丘

Nathan W. Hill

Old Chinese -ak is the most frequent correspondence to Tibetan -ah, but it is unclear whether the other correspondences should be dismissed or somehow explained as descending from divergent proto-forms.

There are two logical ways to combine the Tibetan change $*_{\partial}>a$, for which there is secure evidence, with a change $*_{\partial j}>\mathrm{e}$, under exploration now; either first $*_{\partial}>\mathrm{a}$ and later $*_{a j}>\mathrm{e}$, or first $*_{\partial j}>\mathrm{e}$ and later $*_{\partial}>\mathrm{a}$. If $*_{\partial}>\mathrm{a}$ and then $*_{a j}>\mathrm{e}$ is the correct order, then the examples in Table 2 also become counter evidence.

To have hopes of shedding light on the correspondence of Chinese ${ }^{*}-\partial-$ and Tibetan -e- it would be necessary to find further examples.

\section{Old Chinese *u}

Old Chinese -u- corresponds regularly with Tibetan -u-. There are four correspondences in Burmese: -uiw and - $\bar{u}$ in open syllables, $-\mathrm{o}_{2}$ - before velars, and $-\mathrm{u}-$ before other codas (cf. Table 15). The (near) complementary distribution of the Burmese reflexes suggests that Chinese and Tibetan retain the original form and Burmese has innovated.

Table 15: Correspondences of Old Chinese - $u$ in Tibetan and Burmese

\begin{tabular}{|c|c|c|c|c|c|c|}
\hline & \multicolumn{6}{|c|}{ Open syllables } \\
\hline & Chinese & meaning & Tibetan & meaning & Burmese & meaning \\
\hline 136 & 胞 paew<* ${ }^{{ }^{\varsigma}} \mathrm{ru}(1113 b)$ & womb & phru-ma & afterbirth & - & - \\
\hline 137 & $\begin{array}{l}\text { 舅 gjuwX } \\
<*[\mathrm{~g}](\mathrm{r}) \mathrm{u} ?(1067 \mathrm{~b})\end{array}$ & $\begin{array}{l}\text { maternal } \\
\text { uncle }\end{array}$ & $k h u$ & \begin{tabular}{|l} 
paternal \\
uncle
\end{tabular} & $k u i<*$ kuiw & brother \\
\hline 138 & $\begin{array}{l}\text { 九 } k j u w X<*[\mathrm{k}] \mathrm{u} ? \\
(0992 \mathrm{a})\end{array}$ & nine & $d g u$ & nine & kuih<<*kuiwh & nine \\
\hline 139 & $\begin{array}{l}\text { 鳩 } k j u w<*[k](r) u \\
(0992 n)\end{array}$ & $\begin{array}{l}\text { (a kind of } \\
\text { bird) }\end{array}$ & $h a \dot{n}-g u$ & pigeon & khui<*khuiw & pigeon \\
\hline 140 & 嚊 haw $<^{\#} \mathrm{~g}^{\varsigma} \mathrm{u}(1040 \mathrm{~d})$ & roar, wail & $\dot{n} u$ & weep & $\dot{n} u i<*$ nuiw & weep \\
\hline 141 & $\begin{array}{l}\text { 时 } t r j u w X<* t . k r u ? \\
(1073 a)\end{array}$ & elbow & gru-mo & elbow & - & - \\
\hline 142 & 流 $l j u w<*[\mathrm{r}] \mathrm{u}(1104 \mathrm{a})$ & flow & $r g y u<*^{*} \mathrm{ju}$ & flow & - & - \\
\hline 143 & $\begin{array}{l}\text { 柔 } n y u w<* \text { nu } \\
(1105 a)^{60}\end{array}$ & soft & - & - & $n \bar{u} h$ & soft \\
\hline
\end{tabular}

${ }^{60}$ Gong also compares 揉 nyuw $<{ }^{\#}$ nu (1105b) “make pliable". 
Table 15 (cont.): Correspondences of Old Chinese -u in Tibetan and Burmese

\begin{tabular}{|c|c|c|c|c|c|c|}
\hline & \multicolumn{6}{|c|}{ Velar codas } \\
\hline & Chinese & meaning & Tibetan & meaning & Burmese & meaning \\
\hline 144 & 篤 towk $<^{*} \mathrm{t}^{\varsigma} \mathrm{uk}(1019 \mathrm{~g})$ & firm, solid & $\begin{array}{l}\text { hthug, } \\
\text { mthug }\end{array}$ & $\begin{array}{l}\text { thick, } \\
\text { dense }\end{array}$ & - & - \\
\hline 145 & $\begin{array}{l}\text { 畫 trjuw } H<{ }^{\#} \text { truks } \\
(1075 \mathrm{a})\end{array}$ & $\begin{array}{l}\text { time of } \\
\text { daylight }\end{array}$ & gdugs & $\begin{array}{l}\text { mid-day, } \\
\text { noon }\end{array}$ & - & - \\
\hline 146 & $\begin{array}{l}\text { 覺 kaewk<*k'ruk } \\
(1038 \mathrm{f})^{61}\end{array}$ & awake & dkrug & $\begin{array}{l}\text { stir, agitate, } \\
\text { disturb }\end{array}$ & - & - \\
\hline 147 & $\begin{array}{l}\text { 毒 dowk<*[d]'uk } \\
\text { (1016a) }\end{array}$ & poison & dug & poison & $\begin{array}{l}o_{2} k \\
<* * \text { tuk }\end{array}$ & poison \\
\hline 148 & $\begin{array}{l}\text { 六 ljuwk<*k.ruk } \\
(1032 \mathrm{a})\end{array}$ & six & drug & six & $\begin{array}{l}k h r o_{2} k \\
<* * \text { khruk }\end{array}$ & six \\
\hline 149 & $\begin{array}{l}\text { 腦 } n a w X<* n^{\mathrm{s}}[\mathrm{u}] ? \\
(1244 \mathrm{f})^{62}\end{array}$ & brain & - & - & $\begin{array}{l}n h o_{2} k \\
<* * \text { nhuk }\end{array}$ & brain \\
\hline 150 & $\begin{array}{l}\text { 张 } t \text { tsyuw }<*[\mathrm{t}-\mathrm{q}] \mathrm{uk} \\
(1024 \mathrm{a})\end{array}$ & gruel & thug & soup & - & - \\
\hline 151 & 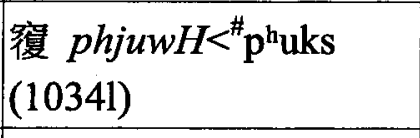 & cover & phug & $\begin{array}{l}\text { cavern, } \\
\text { hole }\end{array}$ & $\begin{array}{l}a-p o_{2} k \\
<* * \text { puk }\end{array}$ & hole \\
\hline \multirow[t]{3}{*}{152} & $\begin{array}{l}\text { 躬 kjuwng<* } \mathrm{k}(\mathrm{r}) \mathrm{u} \\
(1006 \mathrm{f})\end{array}$ & $\begin{array}{l}\text { body, } \\
\text { person }\end{array}$ & - & - & $\begin{array}{l}a-k o_{2} \dot{n} \\
<* * \text { kun }\end{array}$ & $\begin{array}{l}\text { animal body, } \\
\text { dead body }\end{array}$ \\
\hline & \multicolumn{6}{|c|}{ Other codas } \\
\hline & Chinese & meaning & Tibetan & meaning & Burmese & meaning \\
\hline 153 & $\begin{array}{l}\equiv \operatorname{sam}^{<*} \mathrm{sr}[\mathrm{u}] \mathrm{m} \\
(0648 \mathrm{a})\end{array}$ & three & gsum & three & sumh & three \\
\hline 154 & $\begin{array}{l}\text { 尊 tswon }<*[\mathrm{ts}]^{\mathrm{S}} \mathrm{u}[\mathrm{n}] \\
(0430 \mathrm{a})\end{array}$ & honor (v.) & btsun & \begin{tabular}{|l|} 
noble, \\
righteous, \\
honourable
\end{tabular} & - & - \\
\hline 155 & $\begin{array}{l}\text { 昏 } x w o n<* m^{\rho} \mathrm{u}[\mathrm{n}] \\
(0457 \mathrm{k})\end{array}$ & dusk, dark & mun & darkness & mhun & be dim, dusky \\
\hline
\end{tabular}

${ }^{61}$ Gong also compares 攪 kaew $X<* k^{\text {r }}$ ? ? (1038i) "disturb".

${ }^{62}$ The lack of a final $-\mathrm{k}$ in Chinese is an irregularity, which is however seen elsewhere $(\# 72$, 197). 
內藤丘

Nathan W. Hill

Table 15 (cont.): Correspondences of Old Chinese $-\mathrm{u}$ in Tibetan and Burmese

\begin{tabular}{|c|c|c|c|c|c|c|}
\hline & \multicolumn{6}{|c|}{ Other codas (cont.) } \\
\hline & Chinese & meaning & Tibetan & meaning & Burmese & meaning \\
\hline 156 & $\begin{array}{l}\text { 順 zywinH } \\
<^{*} \text { Co.lu[n]s (0462c) }\end{array}$ & follow; obey & Vtul & tame, subdue & - & - \\
\hline 157 & $\begin{array}{l}\text { 訓 } x j u n H<* \mid \mathrm{l} u[\mathrm{n}] \mathrm{s} \\
(0422 \mathrm{~d})^{63}\end{array}$ & instruct & skul & $\begin{array}{l}\text { exhort, } \\
\text { admonish }\end{array}$ & - & - \\
\hline 158 & $\begin{array}{l}\text { 意 } \operatorname{tsyhwinX} \\
<^{\#} \mathrm{t}^{\mathrm{t}} \mathrm{un} \text { ? }(0463 \mathrm{c})^{64}\end{array}$ & stupid & rtul & $\begin{array}{l}\text { blunt, dull, } \\
\text { stupid }\end{array}$ & - & - \\
\hline 159 & $\begin{array}{l}\text { 迪 } x j w i j i X *^{*} \text { maruj? } \\
(0572 a)^{65}\end{array}$ & snake & \begin{tabular}{|l} 
sbrul \\
$<*$ smrul \\
\end{tabular} & snake & mruy & snake \\
\hline 160 & $\begin{array}{l}\text { 水 sywij } X<* \text { s.tur? } \\
(0576 \mathrm{a})\end{array}$ & water & chu & water & $\begin{array}{l}\text { thweh } \\
<* \text { thuyh }\end{array} \mid$ & spittle \\
\hline 161 & $\begin{array}{l}\begin{array}{l}\text { 率綷 lwit<*[r]ut } \\
\text { (0498a-) }\end{array} \\
\end{array}$ & rope & rgyud $<*$ rjud & continuum & - & - \\
\hline 162 & $\begin{array}{l}\text { 卒 } t \text { tswit }<* \text { [ts]ut } \\
(0490 \mathrm{a})^{66}\end{array}$ & finish, die & $V_{s d u}$ & $\begin{array}{l}\text { collect, } \\
\text { gather }\end{array}$ & - & - \\
\hline 163 & $\begin{array}{l}\text { 䔬 pjunH }<^{* *} \mathrm{p}[\mathrm{u}] \mathrm{rs} \\
(0472 \mathrm{a})\end{array}$ & manure, dirt & brun & $\begin{array}{l}\text { dirt, dung, } \\
\text { excrement }\end{array}$ & - & - \\
\hline 164 & $\begin{array}{l}\text { 奔 pwon<* } \mathrm{p}^{\mathrm{s}} \mathrm{ur} \\
(0438 \mathrm{a})\end{array}$ & run (v.) & phun & $\begin{array}{l}\text { accomplish, } \\
\text { complete }\end{array}$ & - & - \\
\hline 165 & $\begin{array}{l}\text { 郡 gjun } K^{*} \text { gurs } \\
(0459 \mathrm{~g})\end{array}$ & district & khul & $\begin{array}{l}\text { district, } \\
\text { province }\end{array}$ & - & - \\
\hline 116 & $\begin{array}{l}\text { 飛 } p j i j<{ }^{*} \mathrm{C} \partial . \mathrm{pu}[\mathrm{r}] \\
(0580 \mathrm{a})\end{array}$ & fly (v.) & hphur & fly (v.) & - & - \\
\hline 107 & 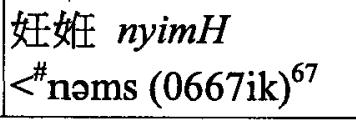 & pregnant & sbrum & pregnant & - & - \\
\hline
\end{tabular}

${ }^{63}$ The initials of the Chinese and Tibetan are not promising.

${ }^{64}$ Gong also compares 鈍 $d w o n H<*{ }^{\text {f }}$ uns "dull" (0427i) (1995/2002:103).

${ }^{65}$ Baxter and Sagart now reconstruct $*[r] \mathrm{u}[\mathrm{j}]$ ? with the irregular sound change $*_{\mathrm{r}}->\mathrm{x}-$. I prefer to follow their earlier reconstruction. Gong compares 閩 min "an ethnonym" (1995/2002: 103) on the mistaken belief that the later means "a kind of snake" (cf. Schuessler 2007:386).

${ }^{66}$ Gong mistakenly analyzes the $-\mathrm{d}$ of the present stem $s d u d$ as part of the root. The Chinese coda compares irregularly with the correct Tibetan root.

${ }^{67}$ Compare footnote 49. 
Table 15 (cont.): Correspondences of Old Chinese $-u$ in Tibetan and Burmese

\begin{tabular}{|c|c|c|c|c|c|c|}
\hline & \multicolumn{6}{|c|}{ Other codas (cont.) } \\
\hline & Chinese & meaning & Tibetan & meaning & Burmese & meaning \\
\hline 105 & $\begin{array}{l}\text { 戡 } k h o m<<^{*} \mathrm{k}^{\mathrm{hs} u m} \\
(0658 \mathrm{q})\end{array}$ & $\begin{array}{l}\text { vanquish, } \\
\text { kill }\end{array}$ & $\sqrt{k u m}$ & kill & - & - \\
\hline 106 & $\begin{array}{l}\text { 尋 zim <*sə-lum } \\
(0662 \mathrm{a})\end{array}$ & $\begin{array}{l}\text { warm up } \\
\text { (food) }\end{array}$ & gtum & $\begin{array}{l}\text { fierce, hot, } \\
\text { angry }\end{array}$ & lum & warm \\
\hline 108 & $\mid \begin{array}{l}\text { 人 nyip }<* \text { nup } \\
(0695 a)\end{array}$ & enter & $n u b$ & to sink, set & niup & $\begin{array}{l}\text { to dive, go } \\
\text { beneath }\end{array}$ \\
\hline
\end{tabular}

The change of *-u- to -o- before velars in Burmese is well known (Maung Wun's law, cf. Maung Wun 1975:88). The correspondence of Burmese -uiw to Tibetan -u and Old Chinese -u as shown in Table 15 strongly suggests a change in open syllables of ${ }^{*} u$ to -uiw. However, a separate correspondence occurs in the comparison of Chinese 柔 nyuw < *nu (1105a) "soft" to Burmese nüh "soft" (\#143). In order to account for these two separate outcomes in Burmese, I reconstruct the correspondence of Chinese and Tibetan " $u$ " with Burmese -uiw as *-uw (2012:75-77) and the correspondence of Chinese and Tibetan " $u$ " with Burmese - $\bar{u}$ as * $u$ (Hill 2012:70, cf. Table 16); this is not an elegant solution.

Table 16: Correspondences of Burmese open syllable $-\overline{\mathrm{u}}$

\begin{tabular}{|c|c|c|c|c|c|c|c|}
\hline & Chine & & meaning & Tibetan & meaning & Burmese & meaning \\
\hline 143 & 柔 nyuw $<*$ nu & $(1105 a)^{68}$ & soft & - & - & $n \bar{u} h$ & soft \\
\hline 166 & - & & - & lus & body & $l \bar{u}$ & person \\
\hline 167 & - & & - & $s u$ & who? & $s \bar{u}$ & him \\
\hline
\end{tabular}

Two of Gong's examples display a correspondence of Old Chinese " $u$ " to Tibetan "a".

Table 17: Correspondence of Chinese $u$ to Tibetan a

\begin{tabular}{|c|c|c|l|l|l|l|}
\hline & \multicolumn{1}{|c|}{ Chinese } & meaning & Tibetan & meaning & Burmese & meaning \\
\hline 168 & 孫 ${\text { swon }<*[\mathrm{~s}]]^{\mathrm{s}} \mathrm{u}[\mathrm{n}](0434 \mathrm{a})}$ grandchild & mtshan & nephew & - & - \\
\hline 169 & 類 $l w i j H<*[\mathrm{r}] \mathrm{u}[\mathrm{t}] \mathrm{s}(0529 \mathrm{a})$ & category & gras & $\begin{array}{l}\text { class, } \\
\text { order }\end{array}$ & - & - \\
\hline
\end{tabular}

${ }^{68}$ Gong also compares 揉 nyuw <" nu (1105b) "make pliable". 
内藤丘

Nathan W. Hill

The comparison of Chinese 孫 swon < *s un (0434a) "grandchild" to Tibetan mtshan "nephew" (Gong 1995/2002:107), in addition to phonological obstacles, faces the problem that the Tibetan word simply does not mean "nephew". The dictionaries offer "name", "mark", "night" and other meanings for mtshan, but "nephew" is not among them. In place of Tibetan gras "class, order" Schuessler compares Tibetan rus "bone, lineage" to Chinese 類 $l w i j H<*[\mathrm{r}] \mathrm{u}[\mathrm{t}] \mathrm{s}$ (0529a) "category" (2009:314). Both of the comparisons in Table 17 should be rejected.

\section{Old Chinese *o}

Old Chinese *o correspondences in Tibetan and Burmese are complicated. In the most simple case all three languages have -o- pointing unambiguously to $*_{o}$ in their common ancestor (cf. Table 18).

Table 18: The correspondence of Old Chinese -o- to -o- in Tibetan and Burmese

\begin{tabular}{|c|c|c|c|c|c|c|}
\hline & Chinese & meaning & Tibetan & meaning & Burmese & meaning \\
\hline 170 & - & - & mtho & span & thw $\bar{\alpha}<*$ tho $_{1}$ & span \\
\hline 171 & - & - & so & tooth & $s w \bar{a} h<{ }^{*} \mathrm{~s}_{1} \bar{b}_{1}$ & tooth \\
\hline 172 & - & - & thon & plough & thwan $<*$ tho $_{1} \mathrm{n}$ & plough \\
\hline 173 & $\begin{array}{l}\text { 絶 dzjwet<*[dz]ot } \\
(0296 \mathrm{a})\end{array}$ & $\begin{array}{l}\text { cut off, } \\
\text { break off }\end{array}$ & chod & be sharp & chwat $<{ }^{*} \mathrm{cho}_{1} \mathrm{t}$ & pluck \\
\hline 174 & $\begin{array}{l}\text { 脫 thwat }<{ }^{*} \mathrm{~m}-f_{\mathrm{f}}^{\mathrm{r}} \mathrm{ot} \\
(0324 \mathrm{~m})\end{array}$ & peel off & glod & $\begin{array}{l}\text { loose, } \\
\text { relaxed }\end{array}$ & $l w a t<\mathrm{lo}_{1} \mathrm{t}$ & be free \\
\hline 175 & $\begin{array}{l}\text { 倌 kwaen }<^{*} \mathrm{kr}^{\mathrm{s}} \text { ons } \\
(01571)\end{array}$ & $\begin{array}{l}\text { servant, } \\
\text { groom }\end{array}$ & khol & servant & kywan $<\mathrm{kyo}_{1} \mathrm{n}$ & slave \\
\hline 176 & $\begin{array}{l}\text { 垂 } d z y w e<*[\mathrm{~d}] \mathrm{oj} \\
(0031 \mathrm{a})\end{array}$ & hang down & hjol & hang down & $l$ lway<* ${ }_{10} \mathrm{o}_{1}{ }^{69}$ & $\begin{array}{l}\text { suspend } \\
\text { from the } \\
\text { shoulder }\end{array}$ \\
\hline 177 & $\begin{array}{l}\text { 卵 lwan } X<* \text { k. } \text { ror? }^{\text {for? }} \\
(0179 \mathrm{a})\end{array}$ & egg & sro-ma & louse egg & - & - \\
\hline 178 & - & - & sbom & $\begin{array}{l}\text { fat, } \\
\text { corpulent }\end{array}$ & phwami $2<{ }^{*}$ pho $_{1} \dot{\mathrm{m}} ?$ & $\begin{array}{l}\text { be fat, } \\
\text { plump }\end{array}$ \\
\hline
\end{tabular}

${ }^{69}$ Gong reconstructs Chinese 垂 $d z y w e<*$ gljual (0031a) "hang down, fall", where the lateral compares more favorably. Schuessler reconstructs *doj (2007:196), like Baxter and Sagart (2011). Luce instead compares Written Burmese chwai < *chwoy "hang". (1985:chart x, \#61). 
Another correspondence has - $\mathrm{o}-$ in Chinese and Tibetan but - $\mathrm{u}$ - in Burmese (cf. Table 19). Matisoff (2003:222) and Hill (2011a:713-714) reconstruct this correspondence as *ow. This suggestion is however not elegant. In Old Chinese -w occurs only as a simple coda or before velars (i.e. -aw, -awk, -iw, -ew, -ewk, but not *-awt, *-ewn, etc.). Reconstructing *ow for the words in Table 19 would result in preChinese rimes such as *-own that would violate this distribution. If one reconstructs *-own in pre-Chinese one would also want to find reason to reconstruct *-awt, *ewn, etc. For the time being I maintain the reconstruction *-ow but intend it primarily as a formal way of keeping account of the contrasting outcomes. ${ }^{70}$

Table 19: The correspondence of -o- in Chinese to -o- in Tibetan but - $u$ - in Burmese

\begin{tabular}{|c|c|c|c|c|c|c|}
\hline & Chinese & meaning & Tibetan & meaning & Burmese & meaning \\
\hline 179 & $\begin{array}{l}\text { 殼 khaewk } \\
<*\left[k^{\mathrm{h}}\right]^{\text {Srok }}(1226 \mathrm{a})\end{array}$ & $\begin{array}{l}\text { hollow shell, } \\
\text { hollow }\end{array}$ & skog & shell, peel & $k h o_{2} k<*$ khuk & bark \\
\hline 180 & $\begin{array}{l}\text { 蜾赢 kwaX.lwaX } \\
<* k^{\varsigma} \text { or? } \mathrm{r}^{\mathrm{s}} \text { or? (0351c, } \\
0014 \mathrm{~b})\end{array}$ & $\begin{array}{l}\text { a kind of } \\
\text { wasp }\end{array}$ & - & - & $k l w e<*$ kluy & $\begin{array}{l}\text { dammer } \\
\text { bee }\end{array}$ \\
\hline 181 & 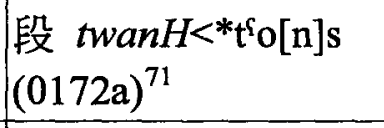 & hammer & tho-ba & $\begin{array}{l}\text { a large } \\
\text { hammer }\end{array}$ & $t \bar{u}$ & hammer \\
\hline 182 & $\begin{array}{l}\text { 儶 } t \text { tsjwen } X<{ }^{\sharp} \text { tson? } \\
(0235 \mathrm{~b})^{72}\end{array}$ & fat, rich & tsho-ba & fat & $\operatorname{ch} \bar{u}$ & be fat \\
\hline 183 & - & - & do & $\begin{array}{l}\text { an equal, } \\
\text { match }\end{array}$ & $t \bar{u}$ & be similar \\
\hline 184 & - & - & Vbo & to sprout & $p h \bar{u}$ & to bud \\
\hline
\end{tabular}

In some cases the lack of a Burmese cognate makes it difficult to distinguish *o from *ow (cf. Table 20).

\footnotetext{
${ }^{70}$ The closed syllables in Chinese compared to the open syllables in Tibetan and Burmese may lead one to question the validity of the comparisons presented in Table 19 altogether.

${ }^{71}$ The presence of a final $-n$ (or $-r$, cf. footnote 32 ) in Chinese is an irregularity.

${ }^{72}$ The presence of a final $-n$ in Chinese is an irregularity.
} 
Table 20: The correspondence of Chinese -o- to Tibetan -owhere a Burmese cognate is missing

\begin{tabular}{|c|c|c|c|c|c|c|}
\hline & Chinese & meaning & Tibetan & meaning & Burmese & meaning \\
\hline 185 & $\begin{array}{l}\text { 蒠 tshuwng }<*[\mathrm{ts}]^{\mathrm{hs}} \text { on } \\
(1199 \mathrm{~g})\end{array}$ & onion & btson & onion & - & - \\
\hline 186 & $\begin{array}{l}\text { 綴 } \text { trjwet }^{\#} \text { trot } \\
(0295 \mathrm{~b})^{73}\end{array}$ & bind & $V_{\text {rtod }}$ & $\begin{array}{l}\text { tether, fasten, } \\
\text { secure }\end{array}$ & - & - \\
\hline 187 & 悅 $y$ wet $<* 10 t(03240)$ & pleased & brod & joy, joyful & - & - \\
\hline 188 & $\begin{array}{l}\text { 掘 gjwot<*[g]ot } \\
(0496 \mathrm{~s})^{74}\end{array}$ & dig out (earth) & rko & dig & - & - \\
\hline 189 & $\begin{array}{l}\text { 涫 } k w a n H<^{\#} \mathrm{k}^{\mathrm{s}} \text { ons } \\
(0157 \mathrm{f})\end{array}$ & bubble & hkhol & boil & - & - \\
\hline 190 & $\begin{array}{l}\text { 唾 } t h w a H<^{\#} \mathrm{t}^{\mathrm{h}} \mathrm{ojs} \\
(0031 \mathrm{~m})\end{array}$ & spit & tho-le & spit & - & - \\
\hline 191 & $\begin{array}{l}\text { 鑽 } t \text { tswan }<*[\text { ts }]^{\text {sor }} \\
(0153 \mathrm{~h})^{75}\end{array}$ & $\begin{array}{l}\text { perforate, } \\
\text { penetrate }\end{array}$ & mtshon & weapon & - & - \\
\hline 192 & $\begin{array}{l}\text { 裹 } k w a X<{ }^{*} \mathrm{~s} .[\mathrm{k}]^{\mathrm{S}} \mathrm{o}[\mathrm{r}] ? \\
(0351 \mathrm{~d})\end{array}$ & wrap (v.) & skor & go around & - & - \\
\hline
\end{tabular}

In a further set of correspondences both Tibetan and Burmese have -u- (cf. Table 21). I propose to reconstruct this correspondence as *-əw-, largely because this syllable fills a gap in Old Chinese (Hill 2012:75-77). This is a tentative suggestion, which faces two potential objections. First, it is somewhat worrisome that examples of

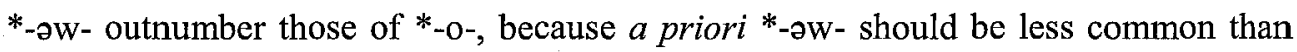

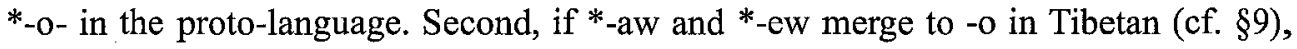

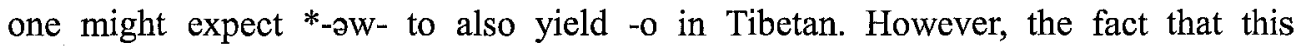
reconstruction is called for only in open syllables or syllables with velar codas (with 洽 heap $<{ }^{*}{ }_{\mathrm{G}}$ rop as the one exception, \#214), by paralleling the distribution of $-\mathrm{w}$ in Old Chinese argues in favour of this reconstruction.

\footnotetext{
${ }^{73}$ Gong also compares 贅 tsywejH< tots (0343a) "unite, together" (1995/2002:86).

${ }^{74}$ The presence of a final $-t$ in Chinese is an irregularity.

${ }^{75}$ Gong also compares 鐎 tsjwen < *tson (0235c) "chisel, sharp point" (1995/2002:86).
} 
Table 21: The correspondence of Chinese -o- to - $\mathrm{u}$ - in Tibetan and Burmese

\begin{tabular}{|c|c|c|c|c|c|c|}
\hline & Chinese & meaning & Tibetan & meaning & Burmese & meaning \\
\hline 193 & 軀 $k h j u<{ }^{\#} \mathrm{k}^{\mathrm{h}} \mathrm{o}(0122 \mathrm{~g})$ & body & $s k u$ & body & - & - \\
\hline 194 & 乳 $n y u X<*$ no? $(0135 a)$ & $\begin{array}{l}\text { milk, } \\
\text { nipple }\end{array}$ & $n u$ & suck & nuiw? & breast \\
\hline 195 & $\begin{array}{l}\text { 寇 khuwH } \\
<*[\mathrm{k}]^{\mathrm{h}}(\mathrm{r}) \mathrm{os}(0111 \mathrm{a})\end{array}$ & steal & $r k u$ & steal & khuiw & steal \\
\hline 196 & 獳 $n y u H<{ }^{\#} \operatorname{nos}(0134 \mathrm{~d})$ & child, mild & $n u-b o$ & $\begin{array}{l}\text { younger } \\
\text { brother }^{76}\end{array}$ & - & - \\
\hline 197 & $\begin{array}{l}\text { 住 } d r j u H<* \text { dro(?)s } \\
(0129 \mathrm{~g})^{77}\end{array}$ & stop (v.) & $h d u g$ & remain, stay & - & - \\
\hline 198 & $\begin{array}{l}\text { 候 huw } \text { h }^{* *}[\mathrm{~g}]^{\S}(\mathrm{r}) \mathrm{os} \\
(0113 \mathrm{e})^{78}\end{array}$ & wait upon & sgug & wait & - & - \\
\hline 199 & $\begin{array}{l}\text { 曲 khjowk }<* \mathrm{k}^{\mathrm{h}}(\mathrm{r}) \mathrm{ok} \\
(1213 \mathrm{a})\end{array}$ & $\begin{array}{l}\text { bent, } \\
\text { crooked }\end{array}$ & hgugs & bend & $\begin{array}{l}k o_{2} k \\
<* * \text { kuk }\end{array}$ & bend (v.) \\
\hline 200 & 穀 $k u w k<^{\#} \mathrm{k}^{\varsigma} \mathrm{ok}$ (1226i) & grain & - & - & $\begin{array}{l}k_{2} k \\
<* * \text { kuk }\end{array}$ & rice plant \\
\hline 201 & $\begin{array}{l}\text { 燭 tsyowk< tok } \\
(1224 \mathrm{e})\end{array}$ & torch & dugs & light, kindle & $t o_{2} k<* *$ tuk & $\begin{array}{l}\text { blaze, flame, } \\
\text { shine }\end{array}$ \\
\hline 202 & $\begin{array}{l}\text { 觸 tsyhowk }<* \mathrm{t}^{\mathrm{h}} \mathrm{ok} \\
(1224 \mathrm{~g})\end{array}$ & \begin{tabular}{|l} 
knock \\
against
\end{tabular} & gtug & meet, touch & - & - \\
\hline 203 & $\begin{array}{l}\text { 㭬 traew } k<^{\#} \operatorname{tr}^{\mathrm{r}} \mathrm{ok} \\
(1218 \mathrm{c})\end{array}$ & beat, strike & rdug & strike against & - & - \\
\hline 204 & $\begin{array}{l}\text { 霧 } m \text { mjuH } \\
<* \operatorname{ka} \cdot \mathrm{m}(\mathrm{r})[\mathrm{o}] \mathrm{ks}(1109 \mathrm{t})\end{array}$ & fog, mist & rmugs & dense fog & - & - \\
\hline 205 & $\begin{array}{l}\text { 俗 zjowk }<* \text { s-[G]ok } \\
(1220 \mathrm{a})\end{array}$ & $\begin{array}{l}\text { popular } \\
\text { usage }\end{array}$ & lugs & way, manner & - & - \\
\hline
\end{tabular}

${ }^{76}$ Gong also compares $n u-m o$ "younger sister".

${ }^{77}$ The lack of a final $-\mathrm{k}$ in Chinese is an irregularity, but a correspondence of Chinese ${ }^{*}$ ? Burmese $-\mathrm{k}$ or Tibetan $-\mathrm{g}$ is seen elsewhere $(\# 72,149)$.

${ }^{78}$ The lack of a final $-\mathrm{k}$ in Chinese is an irregularity.

${ }^{79}$ The comparison of the initials looks more plausible with Schuessler's reconstruction *s-lok (2009:159 §11-14). 
Table 21 (cont.): The correspondence of Chinese -0- to - $\mathrm{u}-$ in Tibetan and Burmese

\begin{tabular}{|c|c|c|c|c|c|c|}
\hline & Chinese & meaning & Tibetan & meaning & Burmese & meaning \\
\hline 206 & $\begin{array}{l}\text { 谷 } k u w k<{ }^{*} \mathrm{C} . \mathrm{q}^{\mathrm{S}} \mathrm{ok} \\
(1202 \mathrm{a})^{80}\end{array}$ & valley & klum & stream, river & $\begin{array}{l}\text { khlo } \dot{n} h \\
<* * \text { khluṇh }\end{array}$ & river \\
\hline 207 & $\begin{array}{l}\text { 欶 sraewk< }{ }^{\#} \mathrm{~s}^{\mathrm{s}} \mathrm{rok} \\
(1222 \mathrm{o})\end{array}$ & $\begin{array}{l}\text { suck, } \\
\text { inhale }\end{array}$ & - & - & $\begin{array}{l}\mathrm{So}_{2} k \\
<* * \text { suk }\end{array}$ & drink \\
\hline 208 & $\begin{array}{l}\text { 痛 thuwng } H<* \text { ! }{ }^{\circ} \text { ons } \\
\text { (1185q) }\end{array}$ & be pained & $g d u \dot{n}$ & $\begin{array}{l}\text { feel pain, be } \\
\text { pained }\end{array}$ & - & 一 \\
\hline 209 & $\begin{array}{l}\text { 墥 draewng } \\
<*[\mathrm{~N}-\mathrm{t}]^{\mathrm{S}} \text { ron }(1188 \mathrm{f})\end{array}$ & strike & $r d u \dot{n}$ & strike, beat & - & - \\
\hline 210 & $\begin{array}{l}\text { 冢 trjowng } X<*[\mathrm{t}] \mathrm{ron} ? \\
(1218 \mathrm{~h})\end{array}$ & $\begin{array}{l}\text { tomb } \\
\text { mound }\end{array}$ & rdun & $\begin{array}{l}\text { small mound, } \\
\text { hillock }\end{array}$ & $t o_{2} \dot{n}<* *$ tun & $\begin{array}{l}\text { hill, } \\
\text { mountain }\end{array}$ \\
\hline 211 & 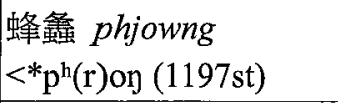 & bee & $b u \dot{n}-b a$ & bee & - & - \\
\hline 212 & $\begin{array}{l}\text { 空 khuwng<** } \mathrm{k}^{\mathrm{hr}} \text { on } \\
(1172 \mathrm{~h})^{81}\end{array}$ & $\begin{array}{l}\text { hollow, } \\
\text { empty, hole }\end{array}$ & khù & $\begin{array}{l}\text { hole, pit, } \\
\text { hollow, cavity }\end{array}$ & $\begin{array}{l}\text { kho }{ }_{2} \text { n்h } \\
<* * \text { khuñh }\end{array}$ & be hollow \\
\hline 213 & $\begin{array}{l}\text { 雔 sraewng }<*[\mathrm{~s}]^{\text {s }} \text { ron } \\
(1200 \mathrm{a})^{82}\end{array}$ & a pair & $\begin{array}{l}z u \dot{n} \\
<* \text { dzun் }\end{array}$ & a pair & cum $^{83}$ & pair \\
\hline 214 & $\begin{array}{l}\text { 洽 heap }<*[\mathrm{G}]^{\mathrm{S}} \mathrm{r}[\mathrm{o}] \mathrm{p} \\
(0675 \mathrm{~m})\end{array}$ & $\begin{array}{l}\text { accord } \\
\text { with }\end{array}$ & hgrub & $\begin{array}{l}\text { accomplish, } \\
\text { achieve }\end{array}$ & - & - \\
\hline
\end{tabular}

Two of Gong's examples exhibit a further correspondence of -o- in Chinese to -ain Burmese.

Table 22: The correspondence of Chinese -o- to -a- in Burmese

\begin{tabular}{|l|l|l|l|l|l|l|}
\hline & Chinese & meaning & Tibetan & meaning & Burmese & meaning \\
\hline 215 & 合 hop $<{ }^{*} \mathrm{~m}-\mathrm{k}^{\mathrm{s}} \mathrm{op}(0675 \mathrm{a})$ & unite & - & - & kap & join, unite \\
\hline 216 & 䢔 $h o p<{ }^{*} \mathrm{~m}-\mathrm{k}^{\mathrm{s}} \mathrm{op}(0675 \mathrm{e})$ & $\begin{array}{l}\text { reach, attain, } \\
\text { go to }\end{array}$ & - & - & khap & arrive at \\
\hline
\end{tabular}

${ }^{80}$ The comparison of the initials looks more plausible with Schuessler's reconstruction *kl ${ }^{\text {' }} \mathrm{ok}$ (2009:158 §11-14). Nonetheless the Chinese final $-\mathrm{k}$ is a problem; a better Chinese comparison to the words in Tibetan and Burmese is probably 江 kaewng $<*^{*} k^{\text {ron }}(1172 \mathrm{v})$ "(Yangzi) river" or potentially 川 tsyhwen <*t.lun (0462a) "river".

${ }^{81}$ Gong also compares 孔 khuwng $X<{ }^{\#} \mathrm{k}^{\mathrm{h}}$ op]? (1174a) "empty" (1995/2002:89-90).

82 The Chinese initial is perhaps unexpected.

${ }^{83}$ The Burmese final is irregular. 
The vowel -ə- is difficult to distinguish from -0- in this syllable position; Schuessler reconstructs both 合 and 䢔 as * ${ }^{\mathrm{g}} \ni p$ (2009:354). If one employs such a reconstruction these two sets of correspondences become regular; they would appear in Table 6.

\section{Old Chinese -w}

Tibetan cognates have the main vowel -o- whenever Old Chinese has final -w, regardless of the main vowel in Old Chinese (cf. Table 23 and Hill 2011a:715-716), because of this the Tibetan correspondences of Old Chinese words ending in -w are best considered together rather than with their respective Old Chinese main vowels. There are too few Burmese cognates to be confident about the correspondences of the various Chinese syllable types in Burmese.

Table 23: Correspondences of Old Chinese - w in Tibetan and Burmese

\begin{tabular}{|c|c|c|c|c|c|c|}
\hline & \multicolumn{6}{|c|}{ Chinese -aw } \\
\hline & Chinese & meaning & Tibetan & meaning & Burmese & meaning \\
\hline 217 & $\begin{array}{l}\text { 耄 maw< }{ }^{\#} m^{\mathrm{S}} \text { aws } \\
(1137 \mathrm{~h})\end{array}$ & very old & rmo-rmo & grandmother & - & - \\
\hline 218 & $\begin{array}{l}\text { 謡 yew<*law } \\
(1144 \mathrm{j})\end{array}$ & sing, song & $l o$ & talk, report & - & - \\
\hline 219 & $\begin{array}{l}\text { 豪 haw }<* \mathrm{~g}^{\Upsilon} \text { aw } \\
(1129 \mathrm{n})\end{array}$ & 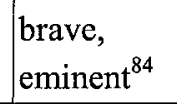 & mgo & head & - & - \\
\hline \multirow[t]{3}{*}{220} & $\begin{array}{l}\text { 號 haw<*[C.g] } \\
\text { (1041q) }\end{array}$ & call out & sgo & say & $k h \bar{o}$ & call \\
\hline & \multicolumn{6}{|c|}{ Chinese -awk } \\
\hline & Chinese & meaning & Tibetan & meaning & Burmese & meaning \\
\hline 221 & $\begin{array}{l}\text { 粼 } d z a k<*[\mathrm{dz}]^{\top} \mathrm{awk} \\
(1128 \mathrm{a})\end{array}$ & chisel & - & - & cho $o_{2} k<* *$ chuk & a chisel \\
\hline 222 & $\begin{array}{l}\text { 駁 paewk< }<^{\#} p^{\mathrm{r}} \mathrm{awk} \\
(1127 \mathrm{a})\end{array}$ & $\begin{array}{l}\text { horse with } \\
\text { mixed } \\
\text { colours }\end{array}$ & - & - & pro $_{2} k<* *$ pruk & $\begin{array}{l}\text { speckled, } \\
\text { spotted }\end{array}$ \\
\hline
\end{tabular}

${ }^{84}$ Baxter and Sagart (2011) instead define "procupine; shaggy animal". 
Table 23 (cont.): Correspondences of Old Chinese -w in Tibetan and Burmese

\begin{tabular}{|l|l|l|l|l|l|l|}
\hline & \multicolumn{7}{|c|}{ Chinese -ewk } \\
\hline & \multicolumn{1}{|c|}{ Chinese } & meaning & \multicolumn{1}{|c|}{ Tibetan } & meaning & Burmese & meaning \\
\hline 223 & $\begin{array}{l}\text { 弱 nyak }<^{*} \text { newk } \\
(1123 \mathrm{a})\end{array}$ & $\begin{array}{l}\text { soft, tender, } \\
\text { weak }\end{array}$ & ñog-ñon & $\begin{array}{l}\text { soft, tender, } \\
\text { weak }\end{array}$ & - & - \\
\hline 224 & $\begin{array}{l}\text { 曜燿耀 yewH } \\
<* \text { lewks (1124ijk) }\end{array}$ & shine (v.) & glog & lightning & - & - \\
\hline
\end{tabular}

\section{Summary of the main correspondences}

Assembling the regular correspondences among Chinese, Tibetan and Burmese discussed throughout this paper yields Table 24. This table does not distinguish nasals and stops, and treats $-\mathrm{r}$ and -1 as dentals. Although final consonants have not been the focus of this study, because (particularly in Burmese) final consonants condition changes in the nuclear vowels, a presentation of the correspondences which takes account of final consonants is more informative than one which does not. In addition, such a presentation allows lacunae in the available data to become more obvious. For example, one may predict that Chinese *-awk would correspond to Tibetan -ok, and perhaps it does, but the absence of cognates supporting this correspondence is noted with a question mark in Table 24 .

Table 24: Regular correspondences among Chinese, Tibetan, and Burmese

\begin{tabular}{|llllll|}
\hline \multicolumn{2}{l}{ main vowel Chinese } & Tibetan & Burmese & \multicolumn{2}{l|}{ reconstruction examples } \\
\hline (a) & $*_{\mathrm{a}}$ & $\mathrm{a}$ & $\mathrm{a}$ & $*_{\mathrm{a}}$ & $\# 229-251$ \\
& $*_{\mathrm{aK}}$ & $\mathrm{aK}$ & $\mathrm{aK}$ & $*_{\mathrm{aK}}$ & $\# 252-287$ \\
& $*_{\mathrm{aT}}$ & $\mathrm{aT}$ & $\mathrm{aT}$ & $*_{\mathrm{aT}}$ & $\# 297-326$ \\
& $*_{\mathrm{aP}}$ & $\mathrm{aP}$ & $\mathrm{aP}$ & $*_{\mathrm{aP}}$ & $\# 288-296$ \\
& $*_{\mathrm{aw}}$ & $\mathrm{o}$ & $\overline{\mathrm{o}}$ & $*_{\mathrm{aw}}$ & $\# 217-220$ \\
& $*_{\mathrm{awk}}$ & $?$ & $\mathrm{uk}$ & $*_{\mathrm{awk}}$ & $\# 221, \# 222$ \\
\hline (i) & $*_{\mathrm{ij}}$ & $\mathrm{i}$ & $\mathrm{iy}$ & $*_{\mathrm{i}}$ & $\# 13-22$ \\
& $*_{\mathrm{iK}}$ & $\mathrm{iK}$ & $\mathrm{aC}<* *_{\mathrm{iK}}$ & $*_{\mathrm{iK}}$ & $\# 23-33$ \\
& $*_{\mathrm{iT}}$ & $\mathrm{iT}$ & $\mathrm{aC}<* *_{\mathrm{iK}}$ & $*_{\mathrm{iT}}$ & $\# 34-41$ \\
& $*_{\mathrm{iP}}$ & $\mathrm{iP}$ & $\mathrm{iP}$ & $*_{\mathrm{iP}}$ & $\# 42-44$ \\
\hline
\end{tabular}

${ }^{85}$ Gong also compares 㷍 yak<"lawk (1119f) "to shine" (1995/2002:87). 
Table 24 (cont.): Regular correspondences among Chinese, Tibetan, and Burmese

\begin{tabular}{|c|c|c|c|c|c|}
\hline \multirow{2}{*}{$\begin{array}{l}\text { main vowel } \\
\text { (e) }\end{array}$} & \multirow{2}{*}{$\begin{array}{l}\text { Chinese } \\
\text { *e }^{2}\end{array}$} & \multirow{2}{*}{$\begin{array}{l}\text { Tibetan } \\
\text { e (?) }\end{array}$} & \multirow{2}{*}{$\begin{array}{l}\text { Burmese } \\
?\end{array}$} & \multicolumn{2}{|c|}{ reconstruction examples } \\
\hline & & & & $*_{\mathrm{e}}$ & $\# 64$ \\
\hline & $* \mathrm{eK}$ & $\mathrm{iK}<*^{*} \mathrm{ek}$ & $\mathrm{aC}<* * \mathrm{iK}$ & *eK & $\# 51-58$ \\
\hline & $*_{\mathrm{eT}} \mathrm{T}$ & $\mathrm{aT}$ & aT & $* \mathrm{eT}$ & $\# 45-50$ \\
\hline & $*_{\mathrm{eP}}$ & $\mathrm{eP}$ & iP & $* \mathrm{eP}$ & $\# 59-61$ \\
\hline & *ew & $?$ & $?$ & $*_{\text {ew }}$ & $\# ?$ \\
\hline & *ewk & ok & $?$ & *ewk & $\# 223,224$ \\
\hline \multirow[t]{6}{*}{ (ә) } & $*_{\partial}$ & a & a & *a & $\# 67-71$ \\
\hline & $*_{\partial \mathrm{K}}$ & $\mathrm{aK}$ & $\mathrm{aK}$ & $*_{\partial \mathrm{K}}$ & $\# 72-82$ \\
\hline & ${ }^{*} ə \mathrm{~T}$ & $\mathrm{aT}$ & $?$ & ${ }^{*} ə \mathrm{~T}$ & \#95-101 \\
\hline & $*_{\partial P}$ & $\mathrm{aP}$ & aP & $*_{\partial} \mathrm{P}$ & $\# 84-93$ \\
\hline & $*_{0}$ & $\mathrm{u}$ & $\mathrm{u}$ & *ow & \#193-196 \\
\hline & $*_{\mathrm{oK}}$ & $\mathrm{uK}$ & $\mathrm{o}_{2} \mathrm{~K}<* * \mathrm{uK}$ & *əw & $\# 197-213$ \\
\hline \multirow[t]{5}{*}{ (u) } & $* u$ & $\mathrm{u}$ & $\mathrm{u}$ & $* \mathrm{u}$ & $\# 143$ \\
\hline & $* \mathrm{uK}$ & $\mathrm{uK}$ & $\mathrm{o}_{2} \mathrm{~K}<* * \mathrm{uK}$ & $* \mathrm{uK}$ & $\# 144-151$ \\
\hline & $*$ uT & $\mathrm{uT}$ & uT & $* \mathrm{uT}$ & $\# 154-165$ \\
\hline & $* u P$ & $\mathrm{uP}$ & $\mathrm{uP}$ & $* \mathrm{uP}$ & $\# 153, \# 105-107$ \\
\hline & $* u$ & $\mathrm{u}$ & uiw & *uw & \#136-142 \\
\hline \multirow[t]{6}{*}{ (o) } & $?$ & o & $\mathrm{o}_{1}$ & $*_{0}$ & $\# 170, \# 171$ \\
\hline & $*_{\mathrm{OT}}$ & $\mathrm{oT}$ & $o_{1} T$ & $*_{\mathrm{oT}}$ & $\# 173-177$ \\
\hline & $?$ & $\mathrm{oK}$ & $?$ & $*_{\mathrm{oK}}$ & $\# 172$ \\
\hline & $?$ & oP & $\mathrm{o}_{1} \mathrm{P}$ & $*_{\mathrm{op}}$ & $\# 178$ \\
\hline & $*_{0}$ & 0 & $\mathrm{u}$ & *ow & $\# 180-184$ \\
\hline & *ok & ok & $\mathrm{o}_{2} \mathrm{~K}<* * \mathrm{uK}$ & $*_{\text {owk }}$ & $\# 179$ \\
\hline
\end{tabular}

\section{Origins of Tibetan -e- and -o-}

Progress in historical linguistics comes through the explanation of irregularities. Consequently, the more frequent irregularities within the data merit special scrutiny. The two most prominent irregularities are the appearance in Tibetan of the vowels -e(cf. Table 25) or -o- (cf. Table 26) where one would expect -a-. 
Table 25: Unexpected instances of -e- in Tibetan

\begin{tabular}{|c|c|c|c|c|c|c|}
\hline & Chinese & meaning & Tibetan & meaning & Burmese & meaning \\
\hline 1 & $\begin{array}{l}\text { 慙 } d z a m<*[\mathrm{dz}]^{\mathrm{S}} \mathrm{am} \\
(0611 \mathrm{c})\end{array}$ & ashamed & hdzem & feel ashamed & - & - \\
\hline 2 & 移 ye<*laj (0003q) & move (v.) & rije & exchange & lai & $\begin{array}{l}\text { change, } \\
\text { exchange }\end{array}$ \\
\hline 3 & $\begin{array}{l}\text { 產 srean } X<*_{\text {s-nrar}} \\
(0194 \mathrm{a})\end{array}$ & $\begin{array}{l}\text { bear }(\mathrm{v} .) \\
\text { produce }\end{array}$ & $V_{\text {srel }}$ & rear, bring up & - & - \\
\hline 62 & $\begin{array}{l}\text { 徧 penH<* } \mathrm{p}^{\mathrm{s}} \mathrm{e}[\mathrm{n}] \mathrm{s} \\
(0246 \mathrm{~b})\end{array}$ & $\begin{array}{l}\text { (go) all } \\
\text { around }\end{array}$ & $V_{\text {pel }}$ & $\begin{array}{l}\text { increase, } \\
\text { augment }\end{array}$ & - & - \\
\hline 63 & $\begin{array}{l}\text { 霚 } \operatorname{sen} H<*[\mathrm{~s}]^{\top} \mathrm{e}[\mathrm{n}] \mathrm{s} \\
(0156 \mathrm{~d})\end{array}$ & sleet & ser & hail & - & - \\
\hline 125 & $\begin{array}{l}\text { 繩 zying<*Cə.lən } \\
(0892 \mathrm{~b})\end{array}$ & rope, cord & hbren & braid & amhyan் & $\begin{array}{l}\text { string, } \\
\text { thread }\end{array}$ \\
\hline 126 & $\begin{array}{l}\text { 娓 } x j w i j j X *{ }^{*} m ə j ? \\
(0583 \mathrm{e})\end{array}$ & burn & mye & fire & $m \bar{l} h$ & fire \\
\hline 128 & $\begin{array}{l}\text { 尾 mijij } X<*[\mathrm{~m}] \text { jj? } \\
(0583 \mathrm{a})\end{array}$ & tail & - & - & $m r i ̄ h$ & tail \\
\hline 129 & 銑 $\operatorname{sen} X<{ }^{\#}$ sor? (0478h) & glossy & gser & gold & - & - \\
\hline 130 & $\begin{array}{l}\text { 饉 } \operatorname{gin} H<*[\mathrm{~g}] \mathrm{r} \cong[\mathrm{r}] \mathrm{s} \\
(0480 \mathrm{r})\end{array}$ & famine & bkren-po & $\begin{array}{l}\text { beggar, destitute } \\
\text { person }\end{array}$ & - & - \\
\hline
\end{tabular}

Table 26: Unexpected instances of Tibetan -o- (= Table 7)

\begin{tabular}{|c|c|c|c|c|c|c|}
\hline & Chinese & meaning & Tibetan & meaning & Burmese & meaning \\
\hline 102 & 息 $s i k<*$ sək (0925a) & breathe & srog & life & sak & $\begin{array}{l}\text { life, } \\
\text { breath }\end{array}$ \\
\hline 103 & $\begin{array}{l}\text { 牧 } m j u w k<* \text { mək } \\
(1037 \mathrm{a})\end{array}$ & herdsman & hbrog $<*$ mrog & nomad & - & - \\
\hline 104 & $\begin{array}{l}\text { 尋 zim<*sə-ləm } \\
(0662 a)\end{array}$ & $\begin{array}{l}\text { measure of } \\
8 \text { chi 尺 }\end{array}$ & $\begin{array}{l}\text { mdom-pa } \\
<* \text { mlom }\end{array}$ & fathom (n.) & lam & $\begin{array}{l}\text { fathom } \\
\text { (n.) }\end{array}$ \\
\hline
\end{tabular}

It is no coincidence that Gong ends his 1980 paper with an argument that -e- and -o- in Tibetan are innovations. For -e- he explains that in Tibetan verb paradigms a non-etymological -e- often arises as a result of derivation (1980/2002:23-24). Gong accepts Coblin's explanation that a suffix -d (which appears as $-\mathrm{s}$ after the grave 
consonants $-\mathrm{b},-\mathrm{g},-\mathrm{m}$, and -n) changes an -a- into an -e- in the present stem of a verb (Coblin 1976:53-54), e.g. $\sqrt{ }$ bya (present byed, past byas, future bya, imperative byos) "do" and لsam (sems, bsams, gsam, soms) "think". By 1995, having found a number of Chinese cognates for Tibetan -e-, Gong had revised his thinking (1995/2002:87). He suggests that Tibetan -e- is the result of the sound changes *-iə- and *-ia- >-e-.

Several of the apparent exceptional instances of Tibetan -e- are regular according to Gong's formulation using Li's Old Chinese reconstructions. ${ }^{86}$

Table 27: Irregular occurrences of Tibetan -ewhich are regular according to Gong's formulation

\begin{tabular}{|lllll|}
\hline Chinese & meaning & \multicolumn{2}{l|}{ Tibetan } & meaning \\
\hline 產 *srianx (0194a) & bear (v.), produce & $V_{\text {srel }}$ & rear, bring up \\
徧 *pians (0246b) & (go) all around & $\sqrt{\text { pel }}$ & increase, augment \\
霞 *sians (0156d) & sleet & ser & hail \\
\hline 銑 *sianx (0478h) & glossy & gser & gold \\
\hline
\end{tabular}

However, although he does not remark on them, some of Gong's proposed cognates contradict his own formulation. There are both cases where the -e- is unpredicted (cf. Table 28) and one word for which -e- is predicted but does not occur (cf. Table 29). In sum, Gong's explanation for the origin of -e- in Tibetan is unacceptable, both because it relies on obsolete Old Chinese reconstructions and because it is internally inconsistent. Reformulated in the perspective of the six vowel hypothesis Gong's account for the origin of Tibetan -e- suggests that Tibeto-Burman ${ }^{*}$-e- and *-ə- become Tibetan $-\mathrm{e}-{ }^{87}$ Such a formulation achieves a much worse description of the data; -a- is a frequent reflex in Tibetan of both $*_{-}$-e- and $*_{-}-$- (cf. Tables 4 and 6).

\footnotetext{
${ }^{86}$ Those examples which here compelled the proposal *-eT $>$-aT have -ja- rather than -ia- in Gong's reconstructions.

${ }^{87}$ This reformulation is based on the six-vowel reconstructions of the words that Gong points to; it is far from the case that one can generally equate *-iə- and *-ia- in Li's system with *-eand ${ }^{*}$-o- in the six-vowel system.
} 
Table 28: Occurences of Tibetan -e- that are unpredicted according to Gong's formulation

\begin{tabular}{|c|c|c|c|}
\hline Chinese & meaning & Tibetan & meaning \\
\hline 饉 *grjəns (0480r) & famine & bkren-po & beggar, destitute person \\
\hline 娓 *smjədx (0583e) & burn & mye & fire \\
\hline 慙 *dzam (0611c) & ashamed & hdzem & feel ashamed \\
\hline
\end{tabular}

Table 29: A case where Gong predicts Tibetan -e- but it does not occur

\begin{tabular}{|l|l|l|l|}
\hline Chinese & meaning & Tibetan & meaning \\
\hline$八 *$ priat (0281a) & eight & brgyad $<*$ brjad & eight \\
\hline
\end{tabular}

If Gong's explanation from 1995 is unsatisfactory, it is worth reconsidering his 1980 proposal that many of the problematic cases of -e- in Tibetan are innovations caused through verbal derivation. In some Tibetan verbs the present stem with -e- is generalized to the entire paradigm. For example, the verb gśegs, gśegs, gśegs, gśegs "go/come" shows no paradigmatic stem changes, but the morphological imperative śogs functions as a suppletive imperative of the verb hon "to come" and Róna-Tas suggets that the past stem of this verb in Balti dialect and the loan adaptation into Mongour must reflect Old Tibetan *gśags (1966:95, \#670). One is entitled to speculate that originally the verb had the paradigm $\sqrt{ }$ śag (gśegs, *bśags, *gśag, śogs) "go/come". In light of such cases, it is possible that the etymological stem vowel in hdzem "be ashamed", rje "exchange", ne "be near", Vsrel "rear", and $V_{\text {pel }}$ "increase" was originally -a- and not -e-. However, this explanation leaves the unanticipated instances of -e- in nouns unaccounted for. One could postulate that such cases are not cognate with the Chinese words they have been compared to, or suggest that they are derived from verbs; either explanation is ad hoc and unsatisfactory. The problem of unanticipated -e- vowels in Tibetan nouns requires additional attention. Other potential accounts of rje "exchange" are also discussed above (cf. §3).

Turning the discussion from the origins of Tibetan -e- to the origins of Tibetan -o-, Gong notes several correspondences of Tibetan -o- in Chinese (cf. Table 30).

Table 30: Correspondences of WrT o in OC following Gong (1995/2002)

\begin{tabular}{|l|l|}
\hline Tibetan & Chinese \\
\hline -o- & -wa- \\
\hline -o- & -wo- \\
\hline -o- & -ua- \\
\hline -o- & -aw- \\
\hline
\end{tabular}


I have elsewhere reconsidered the correspondences of Tibetan -o- (cf. Hill 2011a) and proposed the correspondences summarized in Table 31.

Table 31: Correspondences of Tibetan -o- in Chinese and Burmese

\begin{tabular}{|l|l|l|l|}
\hline Tibeto-Burman & Chinese & Tibetan & \multicolumn{1}{|c|}{ Burmese } \\
\hline *wa $_{\mathrm{a}}$ & $-\mathrm{w}_{\mathrm{a}}-$ & $-\mathrm{o}$ & wa- (Anlaut) \\
\hline *wo & $-\mathrm{w}_{\partial}-$ & $-\mathrm{o}$ & wa- (Anlaut) \\
\hline *o $_{\mathrm{o}}$ & $-\mathrm{o}-$ & $-\mathrm{o}-$ & wa<- $\mathrm{o}_{1}$ - (Inlaut) \\
\hline *ow $_{\text {ow }}$ & $-\mathrm{o}-$ & $-\mathrm{o}-$ & $-\mathrm{u}-\left(\mathrm{o}_{2}\right.$ before velars) \\
\hline *aw $_{\text {aw }}$ & -aw & $-\mathrm{o}$ & $-\overline{0}[\mathrm{au}]$ \\
\hline
\end{tabular}

Nonetheless, these generalizations fail to explain the presence of -o- in the three Tibetan words presented in Table 26; these three words require further research.

\section{Additional irregularities}

The words in three categories of irregular vowel correspondences are here (provisionally) rejected as valid cognates. In the first case, an unambiguous vowel -*əin Chinese corresponds to - $\mathrm{u}$ - in Tibetan (cf. Table 32).

Table 32: An unambiguous -* ${ }^{-}$- in Chinese corresponding to -u- in Tibetan

\begin{tabular}{|c|c|c|c|c|c|c|}
\hline & Chinese & meaning & Tibetan & meaning & Burmese & meaning \\
\hline 109 & $\begin{array}{l}\text { 塵 drin<*[d]ra[n] } \\
(0374 a)\end{array}$ & dust (n.) & $r d u l$ & dust, ashes & - & - \\
\hline 110 & $\begin{array}{l}\text { 銀 } n g i n<* \mathrm{yr} \text { [n] } \\
(0416 \mathrm{k})\end{array}$ & silver & dìul & silver & $\dot{n} u y$ & silver \\
\hline 111 & $\begin{array}{l}\text { 根 kon<* }[\mathrm{k}]^{\mathrm{\rho}} \curvearrowright[\mathrm{n}] \\
(0416 \mathrm{~b})\end{array}$ & root, trunk & khul-ma & $\begin{array}{l}\text { bottom or } \\
\text { side of sth }\end{array}$ & - & - \\
\hline 113 & $\begin{array}{l}\text { 貧 bin<*(Cə.) }[\mathrm{b}] \mathrm{r} \partial[\mathrm{n}] \\
(0471 \mathrm{v})\end{array}$ & poor & $d b u l$ & poor & - & - \\
\hline 114 & $\begin{array}{l}\text { 分 pjun<**o[n] } \\
(0471 \mathrm{a})\end{array}$ & divide & hbul, hphul & give & - & - \\
\hline 115 & $\begin{array}{l}\text { 粉 pjun } X<{ }^{*} \text { mə.pən? } \\
(0471 \mathrm{~d})\end{array}$ & flour & $d b u r$ & smooth (v.) & - & - \\
\hline
\end{tabular}


內藤丘

In the second case, Chinese -*a- corresponds to Tibetan -i- (cf. Table 33). As mentioned above ( $\$ 6$, Table 11), the comparison of 几 to Tibetan khri may also be dismissed on semantic grounds.

Table 33: Chinese -*ə- corresponding to Tibetan -i-

\begin{tabular}{|c|c|c|c|c|c|c|}
\hline & Chinese & meaning & Tibetan & meaning & Burmese & meaning \\
\hline 117 & $\begin{array}{l}\text { 禁 } k i m H<* k r[\partial] \mathrm{ms} \\
(0655 \mathrm{k})\end{array}$ & prohibit & khrims & right, law & - & - \\
\hline 122 & 其 $g i<*$ go (0952a) & ( $3 \mathrm{p}$ possessive) & gyi, etc. & (genitive) & - & - \\
\hline 123 & $\begin{array}{l}\text { 蒢艮 } n g j i<^{\#} \mathrm{y}[\mathrm{n}] \\
(0416-)\end{array}$ & gums & $\begin{array}{l}\mathrm{rñil} / \mathrm{s} \tilde{n} i l \\
<* \mathrm{y}^{\mathrm{j}} \mathrm{il}\end{array}$ & gums & - & - \\
\hline 124 & $\begin{array}{l}\text { 几 } k i j X<* \mathrm{kr} ə \mathrm{j} ? \\
(0602 \mathrm{a})\end{array}$ & stool, small table & $k h r i$ & $\begin{array}{l}\text { emperor, } \\
\text { throne }\end{array}$ & khriy & foot, leg \\
\hline
\end{tabular}

The two cases when Chinese - $u$ - corresponds to Tibetan -a- can also be dismissed (§7, Table 17).

Table 34 (=Table 17): Correspondence of Chinese u to Tibetan a

\begin{tabular}{|c|l|l|l|l|l|l|}
\hline \multicolumn{1}{|c|}{ Chinese } & \multicolumn{1}{|c|}{ meaning } & \multicolumn{1}{|c|}{ Tibetan } & meaning & Burmese & meaning \\
\hline 168 & $\begin{array}{l}\text { 孫 } s w o n<*[\mathrm{~s}]^{\mathrm{s}} \mathrm{u}[\mathrm{n}] \\
(0434 \mathrm{a})\end{array}$ & grandchild & mtshan & nephew & - & - \\
\hline 169 & $\begin{array}{l}\text { 類 } l w i j H^{* *}[\mathrm{r}] \mathrm{u}[\mathrm{t}] \mathrm{s} \\
(0529 \mathrm{a})\end{array}$ & category & gras & class, order & - & - \\
\hline
\end{tabular}

The two cases when Chinese -o- corresponds to Burmese -a- can also be dismissed ( $\$ 8$, Table 22).

Table 35 (= Table 22): The correspondence of Chinese -o- to -a- in Burmese

\begin{tabular}{|l|l|l|l|l|l|l|}
\hline \multicolumn{1}{|c|}{ Chinese } & \multicolumn{1}{|c|}{ meaning } & \multicolumn{1}{c|}{ Tibetan } & meaning & Burmese & meaning \\
\hline 215 & $\begin{array}{l}\text { 合 } h o p<* \mathrm{~m}-\mathrm{k}^{\varsigma} \mathrm{op} \\
(0675 \mathrm{a})\end{array}$ & unite & - & - & $k a p$ & join, unite \\
\hline 216 & $\begin{array}{l}\text { 䢔 } h o p<{ }^{\#} \mathrm{~m}-\mathrm{k}^{\varsigma} \mathrm{op} \\
(0675 \mathrm{e})\end{array}$ & $\begin{array}{l}\text { reach, attain, } \\
\text { go to }\end{array}$ & - & - & $k h a p$ & arrive at \\
\hline
\end{tabular}

In four cases, the cognate sets that Gong proposed present unique vowel correspondences not yet mentioned in this paper. In these words the codas also present 
比較脈絡下的古漢語六元音假說

The Six Vowel Hypothesis of Old Chinese in Comparative Context

irregularities; these proposals are best dismissed so long as the correspondences they exhibit are unique.

Table 36: Unique vowel correspondences

\begin{tabular}{|c|c|c|c|c|c|c|}
\hline & Chinese & meaning & Tibetan & meaning & Burmese & meaning \\
\hline 225 & $\begin{array}{l}\text { 坐 } d z w a X \\
<*[d z]^{\top} \mathrm{o}[\mathrm{j}] ? \text { (0012a) }\end{array}$ & sit & $V_{\text {sdad }}$ & sit, stay & - & - \\
\hline 226 & 眾 $k u<* \mathrm{k}^{\mathrm{w} S \mathrm{a}}(0041 \mathrm{~d})^{88}$ & net & - & - & $k h w a<*$ kho & $\begin{array}{l}\text { a kind of } \\
\text { net }\end{array}$ \\
\hline 227 & $\begin{array}{l}\text { 算 swan } K^{*}{ }^{\prime} s^{\top} \text { ons } \\
(0174 \mathrm{a})\end{array}$ & count & Vśar & $\begin{array}{l}\text { measure, } \\
\text { count }\end{array}$ & - & - \\
\hline 228 & 醪 law< ${ }^{H} \mathrm{r}^{\varsigma} \mathrm{u}(1069 \mathrm{r})$ & $\begin{array}{l}\text { spirits with } \\
\text { sediment }\end{array}$ & ro & taste & - & - \\
\hline
\end{tabular}

Schuessler instead compares the Chinese 醪 law $<{ }^{\#} \mathrm{r}^{\mathrm{s}} \mathrm{u}$ (1069r) "spirits with sediment" to ru-ma "curdled milk" which would make the correspondence regular.

In a number of cases it is possible to disregard comparisons of Gong's, even though they match the normal correspondence of vowels (cf. Table 37). Each case is discussed in the footnotes at the appropriate place, but the arguments for dismissing these correspondences merit repetition here. The Tibetan word jag "robbery" is an exception to Schiefner's law; it should be *bjag or *źag. Because most Tibetan words that with -tse are loans from Chinese (cf. e.g. don-tse "copper coin" < 銅子 tóngzi or lcog-tse "table" < 桌子 $z h u \overline{o z i}$ ) Tibetan rag-tse "stone in a fruit" is probably not an inherited word. Instead of comparing Chinese 翌 / 翼 yik< *Grəp “wing" (0912b, 0954d) to Tibetan lag "hand", the correct cognate is probably hdab-ma "leaf, wing". Chinese 洗洒 $\operatorname{sej} X<*[s]$ `or? $(0478 \mathrm{j} / 0594 \mathrm{~g})$ "wash" may be cognate to Old Tibetan Vstsal "clean, clear", but the correspondence of the initials is irregular, an irregularity hidden by citing the Written Tibetan spelling $V_{s a l}$ "clean, clear". Tibetan ag-po "bad" cannot be of Tibeo-Burman provenance; Jäschke marks this word clearly as a word from a central Tibetan dialect (1881:605). No inherited Tibetan words begin with the final letter of the alphabet. Because the sequence nir- does not occur in inherited Burmese vocabulary (Yanson 2006:104-105), Burmese inrāh "meet" cannot be an inherited word.

\footnotetext{
${ }^{88}$ Gong also compares 罟 $k u X<{ }^{\#} k^{\text {`a? }}$ "net" (0049m) (1995/2002:113).
} 
Table 37: Correspondences to be rejected

\begin{tabular}{|c|c|c|c|c|c|c|}
\hline & Chinese & meaning & Tibetan & meaning & Burmese & meaning \\
\hline 73 & $\begin{array}{l}\text { 賊 } d z o k<* k . d z ` 2 k \\
(0907 \mathrm{a})\end{array}$ & bandit & jag & robbery & - & - \\
\hline 75 & 核 heak< $<^{\#} \operatorname{gr}$ ○k (0937a') & kernel fruit & rag-tse & $\begin{array}{l}\text { stone in } \\
\text { fruits }\end{array}$ & - & - \\
\hline 77 & 翼 yik<*arap (0954d) & wing & $\operatorname{lag}$ & hand, arm & lak & hand, arm \\
\hline 100 & $\begin{array}{l}\text { 洗酒 } \operatorname{sej} X<*[\mathrm{~s}]^{`} \text { `r? } \\
(0478 \mathrm{j} / 0594 \mathrm{~g})\end{array}$ & wash & $V_{\text {stsal }}$ & clean, clear & - & - \\
\hline 258 & 惡 'ak<*?'ak (0805h) & bad, ugly & ag-po & bad & - & - \\
\hline 259 & $\begin{array}{l}\text { 连 ngaeH }<*[\mathrm{n}]^{\mathrm{j}} \text { raks } \\
(0037 \mathrm{f})\end{array}$ & meet & - & - & $\dot{n} r a \bar{h}$ & meet \\
\hline
\end{tabular}

\section{Conclusions}

The six vowel hypothesis of Old Chinese casts a new light on Tibeto-Burman etymological comparisons. Some proposals look more secure (e.g. those in Table 18 for which all three languages retain the original value $\left.{ }^{*}-0-\right)$; other proposals that formerly appeared secure are doubtful (e.g. those in Table 26 and Table 32). The reconstruction of Tibeto-Burman on the basis of a six vowel version of Old Chinese yields a proto-language which also has six vowels, the same six as Old Chinese. The vowel of Old Chinese almost always reflects the etymological vowel. However, three Tibeto-Burman rimes are missing in Old Chinese, i.e. *ow, *əw, and *uw; Chinese merges *ow and *aw with $*_{0}$ and also merges *uw with ${ }^{*} \mathrm{u}$.

More work must be done on distinguishing $*_{\partial}$ and $*_{u} u$ in Old Chinese before labials, velars, and -r. In addition, future research must explain the appearance of -oand -e- in some Tibetan words where the overall sound correspondences would predict -a-. Finally, further investigation should take fuller account of initials, codas, and additional languages than was possible here.

The sound changes proposed here may be summarized as follows. ${ }^{89}$

${ }^{89}$ This list uses the abbreviations: Old Burmese (OB), Old Chinese (OC), Old Tibetan (OT), Tibeto-Burman (TB). 
Burmese

1. $\mathrm{TB} * \mathrm{~g}>\mathrm{OB} a$

2. $\mathrm{TB} * e T>\mathrm{OB} a T$

3. $\mathrm{TB} *_{e}>\mathrm{OB} i$

4. TB $* i K>$ OB $a C$ (Shafer's law)

5. TB $* u w>\mathrm{OB}$ uiw

6. TB *aw $>$ OB uiw

7. TB *ow $>\mathrm{OB} u$

8. pre-Burmese * $u K>\mathrm{OB} o_{2} K$ (Maung Wun's law)

Tibetan

9. TB * $e K>$ OT $i K$ (Dempsey's law)

10. TB $* e T>\mathrm{OT} a T$

11. TB $* w>$ OT $u$

12. $\mathrm{TB} * \partial w>\mathrm{OT} u$

13. TB $* \partial>\mathrm{OT} a$

14. TB ${ }^{*}{ }^{a} a{ }^{*} w_{\partial}, *^{*} a w, *^{*}, *^{*}, *^{*}$ ow $>$ OT $o$

Chinese

15. $\mathrm{TB} * \partial w>\mathrm{OC} o$

16. TB *ow $>$ OC $o$

17. TB *uw $>$ OC $u$

These proposed sound changes largely overlap with those presented in two previous articles (Hill 2011:717, Hill 2012:78), but there are differences. Changes 2, 10 , and 12 are not mentioned in the earlier papers. ${ }^{90}$. The proposal of Tibeto-Burman *-in > *-ik > Burmese -ac, which Hill (2012:74) employs to account for comparisons such as Tibetan sñin "heart" and Burmese nhac $<* *$ nhik "heart" is too speculative to include in the summary list here. ${ }^{91}$

${ }^{90}$ I do not claim to have discovered any of the sound changes presented in this article.

91. This proposal is instead appropriately regulated to footnote 24 above. 


\section{Appendix 1: Tibeto-Burman *a}

\begin{tabular}{|c|c|c|c|c|c|c|}
\hline & Chinese & meaning & Tibetan & meaning & Burmese & meaning \\
\hline 229 & 如 nyo<*na $(0094 \mathrm{~g})$ & as, like, if & $n a$ & if & - & - \\
\hline 230 & 旅 ljoX<*[r]a? (0077a) & military unit & dgra & enemy & - & - \\
\hline 231 & $\begin{array}{l}\text { 咀 } d z j o X<^{\#} \mathrm{dza} ? \\
(0046 \mathrm{u})\end{array}$ & eat & $V_{\mathrm{za}}<*$ dza & eat & cāḥ & eat \\
\hline 232 & $\begin{array}{l}\text { 夫 } b j u<*[\mathrm{~b}](\mathrm{r}) \mathrm{a} \\
(0101 \mathrm{a})\end{array}$ & this, that & pha & yonder & - & - \\
\hline 233 & 胡 $h u<*^{\prime} \varsigma_{a}\left(0049 a^{\prime}\right)$ & how, what? & $g a$ & $\begin{array}{l}\text { (an } \\
\text { interrogative } \\
\text { stem) }\end{array}$ & - & - \\
\hline 234 & 呂 $l j o X<*[\mathrm{r}] \mathrm{a}$ ? (0076a) & $\begin{array}{l}\text { spine; pitch- } \\
\text { pipe }\end{array}$ & gra-ma & $\begin{array}{l}\text { air, bristle, } \\
\text { awn }^{92}\end{array}$ & - & - \\
\hline 235 & 遐 hae $<^{*}[\mathrm{~g}]^{\mathrm{s}} \mathrm{ra}(0033 \mathrm{j})$ & distant & - & - & $k \bar{a}$ & tarry (v.) \\
\hline 236 & $\begin{array}{l}\text { 補 } p u X<* \text { Cə-p } p^{i} a ? \\
\left(0102 \mathrm{c}^{\prime}\right)\end{array}$ & patch & - & - & $\mathrm{p} \overline{\mathrm{a}}$ & $\begin{array}{l}\text { mend, } \\
\text { patch }\end{array}$ \\
\hline 237 & $\begin{array}{l}\text { 父 } b j u X<*[\mathrm{~N}-\mathrm{p}](\mathrm{r}) \mathrm{a} ? \\
(0102 \mathrm{a})\end{array}$ & father & pha & father & pha & father \\
\hline 238 & 吾 $n g u^{*} y^{\mathfrak{f} a}(0058 f)$ & I, my & $\dot{n} a$ & I, me & ṅā & $\mathrm{I}, \mathrm{me}$ \\
\hline 239 & $\begin{array}{l}\text { 五. } n g u X<* C . g^{\mathrm{f} a} \text { ? } \\
(0058 \mathrm{a})\end{array}$ & five & $\ln a$ & five & ṅāḥ & five \\
\hline 240 & $\begin{array}{l}\text { 苦 } k h u X<* \mathrm{k}^{\mathrm{h} S \mathrm{a}} \\
(0049 \mathrm{u})\end{array}$ & bitter & $k h a$ & bitter & khāḥ & bitter \\
\hline 241 & 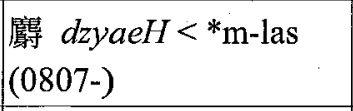 & musk-deer & $g l a-b a$ & musk-deer & - & - \\
\hline 242 & 睹 $t u X<* t^{\mathrm{s} a}$ ? $\left(0045 \mathrm{c}^{\prime}\right)$ & see & lta & look at & - & - \\
\hline 243 & 無 $m j u<* m a(0103 a)$ & not have & $m a$ & not & $\mathrm{ma}$ & not \\
\hline 244 & 魚 $n g j o<^{\#}$ ya (0079a) & fish & $\tilde{n} a<* \dot{n} \dot{j} a$ & fish & ñāḥ & fish \\
\hline 245 & $\begin{array}{l}\text { 女 } n r j o X<* \text { nra? } \\
(0094 \mathrm{a})\end{array}$ & woman & $\tilde{n} a-m o$ & $\begin{array}{l}\text { wife, } \\
\text { housewife }\end{array}$ & - & - \\
\hline
\end{tabular}

${ }^{92}$ The frequently cited meaning "fish bones" is erroneous, arising from a sloppy perusal of Jäschke's definition, which clearly specifies this meaning only in the phrases $\tilde{n} a-g r a$ and $\tilde{n} a h i$ gra-ma (1881:184). 


\begin{tabular}{|c|c|c|c|c|c|c|}
\hline & Chinese & meaning & Tibetan & meaning & Burmese & meaning \\
\hline 246 & 笆 pae $<^{*}$ bria (0039-) & bamboo & $s p a$ & a cane & wăḥ & bamboo \\
\hline 247 & 于 $h j u<{ }^{*} \mathrm{G}^{\mathrm{w}}(\mathrm{r}) \mathrm{a}(0097 \mathrm{a})$ & go & hgro $<*$ hg $^{\mathrm{w}} \mathrm{ra}$ & go & - & - \\
\hline 248 & $\begin{array}{l}F h u X<{ }^{*} m-q^{9} a ? \\
(0053 a)^{93}\end{array}$ & door & $s g o<$ sgwa $^{w}$ & door & - & - \\
\hline 249 & $\begin{array}{l}\text { 羽 } h j u X<*[\mathrm{G}]^{\mathrm{w}}(\mathrm{r}) \mathrm{a} \text { ? } \\
(0098 \mathrm{a})\end{array}$ & feather & sgro $<*$ sgw $^{w} \mathrm{ra}$ & feather & - & - \\
\hline 250 & $\begin{array}{l}\text { 樺 hwaeH< }{ }^{\#} \mathrm{G}^{\mathrm{wS}} \mathrm{ras} \\
(0044-)\end{array}$ & birch & $\begin{array}{l}\text { gro-ga } \\
<* \text { g }^{w} \text { ra-ga }\end{array}$ & birch bark & - & - \\
\hline 251 & $\begin{array}{l}\text { 苧 } h j u H<^{*}[\mathrm{c}]^{w}(\mathrm{r}) \text { as } \\
(0097 \mathrm{o})\end{array}$ & taro & $\begin{array}{l}\text { gro-ma } \\
<*{ }^{w}{ }^{\mathrm{r} a}-\mathrm{ma}\end{array}$ & tuber & wa & tuber \\
\hline 252 & $\begin{array}{l}\text { 赤 tsyhek<*[t-q }](\mathrm{r}) A k \\
(0793 \mathrm{a})\end{array}$ & red & khrag & blood & - & - \\
\hline 253 & $\begin{array}{l}\text { 夜 } y a e H<* \text { N.rAks } \\
(0800 \mathrm{j})\end{array}$ & night & źag<* $\mathrm{r}^{\mathrm{j}} \mathrm{ag}$ & day, $24 \mathrm{hrs}$ & ryak & $\begin{array}{l}\text { day, } \\
24 \mathrm{hrs}\end{array}$ \\
\hline 254 & 絡 lak< ${ }^{\#} \mathrm{r}^{\mathrm{S}} \mathrm{ak}(07660)$ & cord, bridle & Vsgrag $^{94}$ & bind & - & - \\
\hline 255 & $\begin{array}{l}\text { 戝 } k j w a k<^{\#} \mathrm{k}^{\mathrm{w}} \mathrm{ak} \\
(0778 \mathrm{~b})\end{array}$ & $\begin{array}{l}\text { snatch } \\
\text { away, seize }\end{array}$ & $\sqrt{k o g}$ & $\begin{array}{l}\text { take away, } \\
\text { snatch, rob }\end{array}$ & - & - \\
\hline 256 & $\begin{array}{l}\text { 護 } h u H{ }^{* *}[\mathrm{G}]^{w \varsigma} \mathrm{aks} \\
(0784 \mathrm{k})\end{array}$ & $\begin{array}{l}\text { guard, } \\
\text { protect }\end{array}$ & $\begin{array}{l}\text { hgogs } \\
<* \text { hg"wags }^{\text {wa }}\end{array}$ & $\begin{array}{l}\text { prevent, } \\
\text { avert }\end{array}$ & - & - \\
\hline 257 & $\begin{array}{l}\text { 笝 kjwak< } \\
(0778 \mathrm{~b})\end{array}$ & seize & hgog<* hg'wag & $\begin{array}{l}\text { take away } \\
\text { forcibly }\end{array}$ & - & - \\
\hline 258 & 惡 'ak<*?'ak (0805h) & bad, ugly & ag-po & $\mathrm{bad}^{95}$ & - & - \\
\hline 131 & $\begin{array}{l}\text { 百 paek< }{ }^{*} \text { p }^{\mathrm{r}} \text { rak } \\
(0781 \mathrm{a})\end{array}$ & hundred & brgyah $<*$ brjah & hundred & ryā & hundred \\
\hline 132 & 渡 $d u H<^{\#} \mathrm{~d}^{\mathrm{S}} \mathrm{aks}(0801 \mathrm{~b})$ & ford & $h d a h$ & pass over & - & - \\
\hline
\end{tabular}

${ }^{93}$ Gong argues that this word is a hékǒu (合口) syllable (1995/2002:85 footnote 15), which would be *m- $\mathrm{q}^{\text {wSa }}$ ? if one modified the Baxter-Sagart reconstruction.

${ }^{94}$ Gong compares Vgags "bind", but most lexicographical sources do not cite this word Hill (2010:38, 64)

95 Jäschke (1881:605) marks this word clearly as a word from a central Tibetan dialect. No inherited Tibetan words begin with the final letter of the alphabet. This comparison must be disregarded. 


\begin{tabular}{|c|c|c|c|c|c|c|}
\hline & Chinese & meaning & Tibetan & meaning & Burmese & meaning \\
\hline 133 & $\begin{array}{l}\text { 射 zyek<*Co.1Ak } \\
(0807 \mathrm{a})\end{array}$ & $\begin{array}{l}\text { hit with bow } \\
\text { and arrow }\end{array}$ & mdah $<*$ mlah & arrow & mlā & arrow \\
\hline 259 & $\begin{array}{l}\text { 连 ngaeH } \\
<*[\text { [ }]^{\top} \text { raks }(0037 \mathrm{f})\end{array}$ & meet & - & - & ṅrāḥ & meet $^{96}$ \\
\hline 260 & $\begin{array}{l}\text { 膚 } p j u<* \text { pra } \\
(0069 \mathrm{~g})^{97}\end{array}$ & skin & lpags & skin & - & - \\
\hline 261 & $\begin{array}{l}\text { 汝 nyoX<*na? } \\
(0094 \mathrm{j})^{98}\end{array}$ & you & - & - & nan் & you \\
\hline 262 & $\begin{array}{l}\text { 良 ljang }<*[\mathbf{r}] a y \\
(0735 \mathrm{a})\end{array}$ & good & dran்-po & straight & - & - \\
\hline 263 & $\begin{array}{l}\text { 象 zjang } X<*^{*} \text { s- } \\
\text { [d]ay? }(0728 \mathrm{a})\end{array}$ & elephant & glan & ox & - & - \\
\hline 264 & $\begin{array}{l}\text { 張 trjang<*C.tray } \\
(0721 \mathrm{~h})\end{array}$ & draw a bow & than-po & $\begin{array}{l}\text { tense, tight, } \\
\text { firm }\end{array}$ & tanih & $\begin{array}{l}\text { to tighten, } \\
\text { become } \\
\text { tense }\end{array}$ \\
\hline 265 & $\begin{array}{l}\text { 敞 tsyhangX } \\
<* t^{\text {than}}(0725 \mathrm{~m})\end{array}$ & $\begin{array}{l}\text { open, } \\
\text { spacious }\end{array}$ & than & plain (n.) & - & - \\
\hline 266 & $\begin{array}{l}\text { 房 bjang } \\
<* \text { Co-N-pan }(0740 y)\end{array}$ & side-room & $b a \dot{n}-b a$ & storehouse & - & - \\
\hline 267 & $\begin{array}{l}\text { 行 haeng } \\
<* \text { Co.g }{ }^{\mathrm{r}} \text { ray }(0748 \mathrm{a})\end{array}$ & walk (v.) & rkan்-pa & $\begin{array}{l}\text { foot, leg, } \\
\text { hind-foot }\end{array}$ & - & - \\
\hline 268 & $\begin{array}{l}\text { 楊 yang<*lay } \\
(0720 \mathrm{q})\end{array}$ & poplar & glan-ma & $\begin{array}{l}\text { a large kind } \\
\text { of alpine } \\
\text { willow }\end{array}$ & - & - \\
\hline 269 & $\begin{array}{l}\text { 揚 yang<*1ay } \\
(0720 \mathrm{j})\end{array}$ & raise & Vlań & to rise & lan? & $\begin{array}{l}\text { high raised } \\
\text { frame, } \\
\text { stage }\end{array}$ \\
\hline
\end{tabular}

\footnotetext{
${ }^{96}$ I cannot confirm this Burmese word. According to Yanson nir- is not an onset that occurs in inherited Burmese vocabulary (2006:104-105).

${ }^{97}$ The lack of a final $-\mathrm{k}$ in Chinese is an irregularity.

${ }^{98}$ The lack of a final $-\mathrm{y}$ in Chinese is an irregularity
} 


\begin{tabular}{|c|c|c|c|c|c|c|}
\hline & Chinese & meaning & Tibetan & meaning & Burmese & meaning \\
\hline 270 & $\begin{array}{l}\text { 永 hjwaeng } X \\
<*[\mathrm{G}]^{\mathrm{w}} \operatorname{ran} ?(0764 \mathrm{a})^{99}\end{array}$ & long (time) & rgyań-ma & distance & - & - \\
\hline 271 & $\begin{array}{l}\text { 攘 nyang<*nay } \\
(0730 \mathrm{e})\end{array}$ & $\begin{array}{l}\text { oppose, } \\
\text { disturb }\end{array}$ & - & - & nhan & $\begin{array}{l}\text { drive, drive } \\
\text { away }\end{array}$ \\
\hline 135 & $\begin{array}{l}\text { 曩 } n a n g X<{ }^{*} n^{\mathrm{f}} \text { ay? } \\
(0730 \mathrm{k})^{100}\end{array}$ & $\begin{array}{l}\text { in past } \\
\text { times }\end{array}$ & gnah-bo & $\begin{array}{l}\text { ancient, in } \\
\text { old time }\end{array}$ & - & - \\
\hline 272 & $\begin{array}{l}\text { 瀼 nyang }<\text { \#ay } \\
(0730 \mathrm{f})\end{array}$ & $\begin{array}{l}\text { heavy with } \\
\text { dew }\end{array}$ & $n a-b u n$ & fog $^{101}$ & nhañh & $\begin{array}{l}\text { dew, fog, } \\
\text { mist }\end{array}$ \\
\hline 273 & $\begin{array}{l}\text { 妨 phjang<* } p^{\text {han }} \\
(0740 q)\end{array}$ & oppose & - & - & paṇh & $\begin{array}{l}\text { impede, } \\
\text { instruct }\end{array}$ \\
\hline 274 & $\begin{array}{l}\text { 陽 yang<*lan } \\
(0720 \mathrm{e})\end{array}$ & bright & - & - & lan̉h & $\begin{array}{l}\text { be light, } \\
\text { not dark }\end{array}$ \\
\hline 275 & $\begin{array}{l}\text { 臟 } t \text { tsang<*[ts }]^{\mathrm{f}} \text { ay } \\
(0727 \mathrm{f})\end{array}$ & good & $b z a \dot{n}<*$ bdzan் & good & - & - \\
\hline 276 & $\begin{array}{l}\text { 漿 tsjang<*[ts]an } \\
(0727 \mathrm{v})\end{array}$ & $\begin{array}{l}\text { rice-water } \\
\text { drink }\end{array}$ & chan & barely beer & - & - \\
\hline 277 & $\begin{array}{l}\text { 讓 nyang } H<* \text { nays } \\
(0730 \mathrm{i})\end{array}$ & yield(v.) & gnan் & give & nhaṇh & give \\
\hline 278 & $\begin{array}{l}\text { 涼 ljang<*C.ran } \\
(07551)\end{array}$ & cold & gran் & cold & - & - \\
\hline 279 & $\begin{array}{l}\text { 量 ljang }<*[\mathrm{r}] \mathrm{ay} \\
(0737 \mathrm{a})\end{array}$ & measure & grañs & number & khran & $\begin{array}{l}\text { measure } \\
(\mathrm{v} .)\end{array}$ \\
\hline 280 & 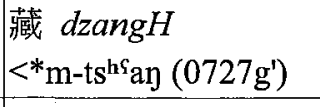 & $\begin{array}{l}\text { store, } \\
\text { repository }\end{array}$ & gstsan & $\begin{array}{l}\text { conceal, } \\
\text { secret }\end{array}$ & - & - \\
\hline 281 & $\begin{array}{l}\text { 梗 kaeng } X<* k^{\text {个ran}} \text { ? } \\
(0745 \mathrm{e})\end{array}$ & suffering & mkhran & hard, solid & rani? & $\begin{array}{l}\text { mature, } \\
\text { firm }\end{array}$ \\
\hline 282 & $\begin{array}{l}\text { 紡 phjang } X<{ }^{*} p^{\mathrm{h}} \text { ay? } \\
(0740 \mathrm{r})\end{array}$ & spin & phan் & spindle & wan?? & spin \\
\hline
\end{tabular}

99 This comparison was suggested by Bodman (1980:88).

${ }^{100}$ The correspondence of the codas is irregular.

${ }^{101}$ Gong also compares Tibetan khug-rna / khug-rna "fog, mist" (1995/2002:109-110). The codas of all the Tibetan comparanda are irregular. 
内藤丘

Nathan W. Hill

\begin{tabular}{|c|c|c|c|c|c|c|}
\hline & Chinese & meaning & Tibetan & meaning & Burmese & meaning \\
\hline 283 & $\begin{array}{l}\text { 岡 kang }<^{\#} k^{\varsigma} a n \\
(0697 a)\end{array}$ & hill & sgan & hill & khan & hill \\
\hline 284 & $\begin{array}{l}\text { 放 pjang } H^{<*} \text { pans } \\
(0740 \mathrm{i})\end{array}$ & $\begin{array}{l}\text { release; let } \\
\text { go }\end{array}$ & Vspan & let go, banish & phan?? & $\begin{array}{l}\text { procrastinate, } \\
\text { delay }\end{array}$ \\
\hline 285 & $\begin{array}{l}\text { 皇 hwang<*[G]wiay } \\
(0708 \mathrm{a})\end{array}$ & sovereign & $\begin{array}{l}\text { gon-ma } \\
<{ }^{*} \mathrm{~g}^{\mathrm{w}} \mathrm{an}-\mathrm{ma}\end{array}$ & $\begin{array}{l}\text { higher one, } \\
\text { superior }\end{array}$ & - & - \\
\hline 286 & $\begin{array}{l}\text { 惶 hwang }<^{\#}[\mathrm{G}]^{\mathrm{w}} \text { ay } \\
(0708-)\end{array}$ & fear & $\begin{array}{l}\text { hgon } \\
<* \text { hgwan }\end{array}$ & be afraid & - & - \\
\hline 287 & $\begin{array}{l}\text { 往 hjwang } X<*_{\mathrm{G}^{\mathrm{w}}} \text { an? } \\
(0739 \mathrm{k})^{102}\end{array}$ & go & hor $<* h^{w}$ an & come & wañ & go, come \\
\hline 288 & $\begin{array}{l}\text { 甲 } k a e p<*[\mathrm{k}]^{\mathrm{S}} \mathrm{r}[\mathrm{a}] \mathrm{p} \\
(0629 \mathrm{a})\end{array}$ & shell & khrab & $\begin{array}{l}\text { armour, } \\
\text { shield, mail }\end{array}$ & - & - \\
\hline 289 & $\begin{array}{l}\text { 接 } t \text { sjep }<*[\mathrm{ts}] \mathrm{ap} \\
(0635 \mathrm{e})\end{array}$ & $\begin{array}{l}\text { connect } \\
\text { with }\end{array}$ & - & - & cap & join, unite \\
\hline 290 & 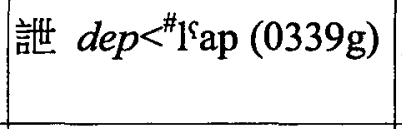 & garrulous & $l a b$ & $\begin{array}{l}\text { speak, talk, } \\
\text { tell (v.) }\end{array}$ & - & - \\
\hline 291 & $\begin{array}{l}\text { 蓋 } k a j H^{* *}[\mathrm{k}]^{\mathrm{s} a p s} \\
(0642 \mathrm{q})\end{array}$ & $\begin{array}{l}\text { thatch, } \\
\text { cover (v.) }\end{array}$ & $\sqrt{ }$ kab & cover (v.) & - & - \\
\hline 292 & $\begin{array}{l}\text { 監 } l a m<* N-k . r^{r} a m \\
(0609 k)\end{array}$ & indigo & rams & indigo & - & - \\
\hline 293 & $\begin{array}{l}\text { 談 dam }<^{\#} 1 \mathrm{am}^{103} \\
(06171)\end{array}$ & to speak & gtam & speech & - & - \\
\hline 294 & $\begin{array}{l}\text { 擔 } \operatorname{tam}<{ }^{\#} \mathrm{t}^{\mathrm{s}} \mathrm{am} \\
(0619 \mathrm{k})\end{array}$ & carry & - & - & thamh & $\begin{array}{l}\text { carry on the } \\
\text { shoulder }\end{array}$ \\
\hline 295 & ${ }^{104}$ & - & mnam & smell & namh & smell \\
\hline 296 & - & - & snam-gźog & side & nam & $\begin{array}{l}\text { side of the } \\
\text { body }\end{array}$ \\
\hline
\end{tabular}

${ }^{102}$ Gong does not include the Chinese member of the comparison.

${ }^{103}$ Gong cites this character as 617e but prints 6171; he reconstructs *gdam (1995/2002:118).

${ }^{104}$ Gong offers no Chinese comparanda for \#295 or \#296; if a Chinese cognate were to have the vowel $ə$ these two correspondences would instead appear in Table 6. 


\begin{tabular}{|c|c|c|c|c|c|c|}
\hline & Chinese & meaning & Tibetan & meaning & Burmese & meaning \\
\hline 297 & $\begin{array}{l}\text { 末 mat<* }{ }^{\Upsilon} a t \\
(0277 \mathrm{a})\end{array}$ & $\begin{array}{l}\text { end of a } \\
\text { branch }\end{array}$ & smad & $\begin{array}{l}\text { the lower } \\
\text { part }\end{array}$ & - & - \\
\hline 298 & $\begin{array}{l}\text { 殺 sreat }<*_{\text {srat }} \\
(0319 \mathrm{~d})\end{array}$ & kill & $\gamma_{\text {sad }}$ & kill & sat & kill \\
\hline 299 & 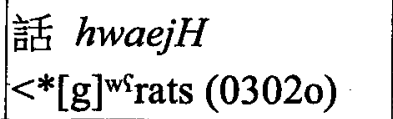 & $\begin{array}{l}\text { speak; } \\
\text { words }\end{array}$ & gros $<{ }^{*} \mathrm{~g}^{\mathrm{w}}$ ras & speech, talk & - & - \\
\hline 300 & $\begin{array}{l}\text { 越 hjwot<*[c]wat } \\
(0303 \mathrm{e})\end{array}$ & pass over & ل & go, walk & - & - \\
\hline 301 & $\begin{array}{l}\text { 糲 ljejH } \\
<*([\mathrm{~m}] \text { - }) \mathrm{r}^{\mathrm{s}} \text { ats }(0340 \mathrm{~g})\end{array}$ & rice & bbras $<*$ hgmras & rice & - & - \\
\hline 302 & $\begin{array}{l}\text { 偽 ngjweH } \\
<^{*}[\mathrm{~N}]-\mathrm{G}^{\mathrm{w}}(\mathrm{r}) \mathrm{ajs} \\
(0027 \mathrm{k})\end{array}$ & false, cheat & rnod<* rñ ${ }^{w}$ at & deceive & - & - \\
\hline 303 & $\begin{array}{l}\text { 殘 dzan<* }{ }^{*}[\mathrm{dz}]^{\mathrm{I} a}[\mathrm{n}] \\
(0155 \mathrm{c})\end{array}$ & $\begin{array}{l}\text { injure, } \\
\text { remnant }\end{array}$ & gzan<* gdzan & $\begin{array}{l}\text { wear out, } \\
\text { hurt, waste }\end{array}$ & - & - \\
\hline 304 & 連 ljen $<"$ ran (0213a) & $\begin{array}{l}\text { connect, } \\
\text { unite in a } \\
\text { row }\end{array}$ & gral & row & - & - \\
\hline 305 & $\begin{array}{l}\text { 炭 than } H<*\left[\mathrm{t}^{\mathrm{t}}\right]{ }^{\mathrm{s}} \mathrm{a}[\mathrm{n}] \mathrm{s} \\
(0151 \mathrm{a})\end{array}$ & $\begin{array}{l}\text { charcoal, } \\
\text { coal }\end{array}$ & thal & dust, ashes & - & - \\
\hline 306 & $\begin{array}{l}\text { 半 pan }{ }^{\circ *} \mathrm{p}^{\Upsilon} \text { ans } \\
(0181 \mathrm{a})\end{array}$ & half & bar & $\begin{array}{l}\text { intermediate } \\
\text { space }\end{array}$ & - & - \\
\hline 307 & $\begin{array}{l}\text { 緾 drjen<* }<\mathrm{d}] \mathrm{ra}[\mathrm{n}] \\
(0204 \mathrm{c})\end{array}$ & bind, wind & star & $\begin{array}{l}\text { tie fast, } \\
\text { fasten to }\end{array}$ & tà & cling to \\
\hline 308 & $\begin{array}{l}\text { 板 } p a e n X<{ }^{*} \mathrm{C} . p^{\mathrm{S}} \mathrm{ran} ? \\
(0262 \mathrm{j})\end{array}$ & $\begin{array}{l}\text { plank, } \\
\text { board }\end{array}$ & bphar & $\begin{array}{l}\text { board, flat } \\
\text { board }\end{array}$ & prāḥ & flat, level \\
\hline 309 & $\begin{array}{l}\text { 緩 hwanX } \\
\sum^{* *}[\mathrm{G}]{ }^{\mathrm{wS} \mathrm{a}}[\mathrm{n}] \text { ? (02551) }\end{array}$ & slack; slow & hgor $<*$ hgwar & tarry, linger & - & - \\
\hline 310 & $\begin{array}{l}\text { 援 hjwon }<*[\mathrm{c}]^{\mathrm{w} a}[\mathrm{n}] \\
(0255 \mathrm{e})\end{array}$ & pull up & hgrol<*hg"wral & become free & - & - \\
\hline
\end{tabular}




\begin{tabular}{|c|c|c|c|c|c|c|}
\hline & Chinese & meaning & Tibetan & meaning & Burmese & meaning \\
\hline 311 & $\begin{array}{l}\text { 丹 } \tan <*_{\mathrm{t}} \mathrm{an} \\
(0150 \mathrm{a})^{105}\end{array}$ & cinnabar & - & - & $\mathrm{tā}$ & $\begin{array}{l}\text { very red, } \\
\text { flaming } \\
\text { red }\end{array}$ \\
\hline 312 & 顫 syen $<^{\#} \mathrm{~s} \cdot \tan (0148 \mathrm{~s})$ & $\begin{array}{l}\text { shivering, } \\
\text { trembling }\end{array}$ & hdar & $\begin{array}{l}\text { tremble, } \\
\text { shudder }\end{array}$ & - & 一 \\
\hline 313 & 斿 $t$ syen $<^{\#} \tan (0150 \mathrm{c})$ & $\begin{array}{l}\text { a kind of } \\
\text { flag }\end{array}$ & $d a r$ & flag & - & - \\
\hline 314 & $\begin{array}{l}\text { 粲 tshan } H<*\left[\mathrm{ts}^{\mathrm{h}}\right]^{\mathrm{S}} \text { ars } \\
(0154 \mathrm{~b})\end{array}$ & $\begin{array}{l}\text { bright and } \\
\text { white }\end{array}$ & mtshar & $\begin{array}{l}\text { fair, } \\
\text { beautiful, } \\
\text { bright }\end{array}$ & - & - \\
\hline 315 & 竿 $k a n<{ }^{*} \mathrm{k}^{\mathrm{f}} \operatorname{ar}(0139 \mathrm{k})$ & pole, rod & mkhar/hkhar & staff, stick & - & - \\
\hline 316 & 難 $n a n<* n^{\Upsilon} \operatorname{ar}(0152 d)$ & difficult & mnar & $\begin{array}{l}\text { suffer, be } \\
\text { tormented }\end{array}$ & - & 一 \\
\hline 317 & 㿋 $\tan X<^{\#} \mathrm{t} \varsigma$ ar? $(01471)$ & $\begin{array}{l}\text { disease, } \\
\text { suffering, } \\
\text { distress }\end{array}$ & ldar & $\begin{array}{l}\text { be weary, } \\
\text { tired, faint }\end{array}$ & - & 一 \\
\hline 318 & $\begin{array}{l}\text { 扞捍 } h a n H<* \mathrm{~m}-\mathrm{k}^{\mathrm{\varsigma}} \mathrm{a}[\mathrm{r}] \mathrm{s} \\
\left(0139 \mathrm{q}, 0139 \mathrm{i}^{\prime}\right)^{106}\end{array}$ & $\begin{array}{l}\text { shield (n.), } \\
\text { ward off }\end{array}$ & hgal & $\begin{array}{l}\text { oppose, } \\
\text { contradict }\end{array}$ & $k \bar{a}$ & shield n. \\
\hline 319 & $\begin{array}{l}\text { 肝 kan<*s. } \mathrm{k}^{\complement} \mathrm{a}[\mathrm{r}] \\
(01391)\end{array}$ & liver & mkhal & kidney, reins & khāḥ & $\begin{array}{l}\text { loins, } \\
\text { waist }\end{array}$ \\
\hline 320 & $\begin{array}{l}\text { 鼾 } x a n<\#\left[q^{\mathrm{h}}\right]^{\mathrm{S}} \mathrm{a}[\mathrm{r}] \text { ? } \\
(0139-)\end{array}$ & snore & hal & pant, snort & - & - \\
\hline 321 & $\begin{array}{l}\text { 餐 } t \text { shan }{ }^{\#} \mathrm{ts}^{\mathrm{h}} \mathrm{ar} \\
(0154 \mathrm{c})\end{array}$ & $\begin{array}{l}\text { eat, food, } \\
\text { meal }\end{array}$ & tshal-ma & breakfast & - & - \\
\hline 322 & $\begin{array}{l}\text { 獻 } s a<* s-\eta]^{\complement} a r \\
(0252 e)^{107}\end{array}$ & $\begin{array}{l}\text { offer, } \\
\text { present, } \\
\text { wise man }\end{array}$ & snar & $\begin{array}{l}\text { intelligent, } \\
\text { quick of } \\
\text { apprehension }\end{array}$ & - & - \\
\hline 323 & $\begin{array}{l}\text { 垣 hjwon<*[G]war } \\
(0164 \mathrm{~m})^{108}\end{array}$ & wall & gron் $<* \mathrm{~g}^{\mathrm{w}} \mathrm{ran}$ & village, town & 一 & - \\
\hline
\end{tabular}

\footnotetext{
${ }^{105}$ The correspondence of the codas is irregular.

${ }^{106}$ Gong also compares Chinese F kan $<{ }^{*} \mathrm{k}^{\mathrm{G}} \mathrm{a}[\mathrm{r}]$ (0139a) "protect, guard" (1995/2002:91).

${ }^{107}$ Gong also compares Chinese 義 $n g j e H<*_{1}$ (r)ajs (0002r) "duty, justice" (1995/2002:105).

${ }^{108}$ The correspondence of Old Chinese $-r$ and Tibetan $-\dot{n}$ is irregular.
} 


\begin{tabular}{|c|c|c|c|c|c|c|}
\hline & Chinese & meaning & Tibetan & meaning & Burmese & meaning \\
\hline 324 & $\begin{array}{l}\text { 乾 } k a n<*[\mathrm{k}]^{\varsigma} \mathrm{ar} \\
(0140 \mathrm{c})^{109}\end{array}$ & dry & - & 一 & khanh & dried up \\
\hline 4 & $\begin{array}{l}\text { 河 } h a<^{*} \mathrm{C} .[\mathrm{g}]^{\mathrm{s}} \mathrm{aj} \\
(0001 \mathrm{~g})\end{array}$ & river & rgal & cross, ford & - & - \\
\hline 5 & 加 $k a e<{ }^{*} \mathrm{k}^{\complement}$ raj $(0015 \mathrm{a})$ & add & khral & $\operatorname{tax}$ & - & - \\
\hline 6 & $\begin{array}{l}\text { 罷疲 bje }<*[\mathrm{~b}] \mathrm{raj} \\
(0026 \mathrm{a}, 0025 \mathrm{~d})\end{array}$ & fatigue & $\begin{array}{l}\text { brgyal } \\
<* \text { brjal }\end{array}$ & $\begin{array}{l}\text { sink down, } \\
\text { faint }\end{array}$ & - & - \\
\hline 7 & 荷 $h a<*[g]^{\varsigma}$ aj (0001o) & carry & khal & burden, load & $\mathrm{ka}$ & $\begin{array}{l}\text { saddle- } \\
\text { frame }\end{array}$ \\
\hline 8 & $\begin{array}{l}\text { 披 } p h j e^{<*} \mathrm{p}^{\mathrm{h}}(\mathrm{r}) \mathrm{aj} \\
(0025 \mathrm{j})^{110}\end{array}$ & divide & hphral & $\begin{array}{l}\text { be separate, } \\
\text { to part }\end{array}$ & prāḥ & $\begin{array}{l}\text { be divided } \\
\text { into parts }\end{array}$ \\
\hline 9 & 篱 lje $<^{\#}$ raj $(0023 \mathrm{~g})$ & hedge & $r a$ & courtyard & - & - \\
\hline 10 & 羅 la<* ${ }^{\complement}$ aj (0006a) & $\begin{array}{l}\text { a kind of } \\
\text { net }\end{array}$ & $d r a$ & net & - & - \\
\hline 11 & 波 $p a<^{\#} \mathrm{p}^{\mathrm{c}_{\mathrm{c}} \mathrm{j}(00251)}$ & wave & $d b a h$ & wave & - & - \\
\hline 325 & $\begin{array}{l}\text { 㢁 tsyhe } X<{ }^{\#} \mathrm{k} \text {-laj? } \\
(0003 \mathrm{t})\end{array}$ & $\begin{array}{l}\text { wide, } \\
\text { extend }\end{array}$ & - & - & klay & $\begin{array}{l}\text { wide, } \\
\text { broad }\end{array}$ \\
\hline 326 & 多 $t a<*[t-1]^{\top}$ aj $(0003 a)$ & many & - & - & tay & $\begin{array}{l}\text { very } \\
\text { (intensive) }\end{array}$ \\
\hline
\end{tabular}

${ }^{109}$ Gong also compares Chinese 旱 $\operatorname{han} X<*[\mathrm{~g}]^{\S} \mathrm{a}[\mathrm{r}]$ ? (0139s) “drought, dry" (1995/2002:106).

${ }^{110}$ Gong also compares Chinese 離 lje $<*[\mathrm{r}] \mathrm{aj}(0023 \mathrm{f})$ "depart from" (1995/2002:104). 
內藤丘

Nathan W. Hill

\section{Appendix 2: Concordance of examples in Gong 1995}

\begin{tabular}{|c|c|c|c|}
\hline GSR number & Chinese & Gong 1995 number & Number here \\
\hline & no Chinese ${ }^{111}$ & 103 & \\
\hline & no Chinese & 104 & 295 \\
\hline & no Chinese & 105 & 296 \\
\hline $0001 \mathrm{~g}$ & 河 $h a$ & 164 & 4 \\
\hline 00010 & 荷 $h a$ & 165 & 7 \\
\hline $0002 r$ & 義 $n g j e H$ & 185 & 322, n. 107 \\
\hline $0003 a$ & 多 $t a$ & 114 & 326 \\
\hline $0003 q$ & 移 ye & 115 & 2 \\
\hline $0003 \mathrm{t}$ & 㢋 tsyheX & 121 & 325 \\
\hline $0004 b^{\prime}$ & 地 $d i j H$ & not in Gong 1995 & 65 \\
\hline $0006 a$ & 羅 la & 116 & 10 \\
\hline $0012 \mathrm{a}$ & 坐 $d z w a X$ & 43 & 225 \\
\hline $0015 \mathrm{a}$ & 加 kae & 163 & 5 \\
\hline $0023 \mathrm{f}$ & 離 lje & 166 & 8, n. 110 \\
\hline $0023 \mathrm{~g}$ & 籬 lje & 120 & 9 \\
\hline $0025 \mathrm{~d}$ & 疲 bje & 167 & 6 \\
\hline $0025 \mathrm{j}$ & 披 phje & 166 & 8 \\
\hline 00251 & 波 $p a$ & 113 & 11 \\
\hline $0026 \mathrm{a}$ & 罷 bje & 167 & 6 \\
\hline $0027 \mathrm{k}$ & 偽 ngjweH & 211 & 302 \\
\hline $0031 \mathrm{a}$ & 垂 $d z y w e$ & 45,168 & 176 \\
\hline $0031 \mathrm{~m}$ & 唾 $t h w a H$ & 119 & 190 \\
\hline $0033 \mathrm{j}$ & 澱 hae & 299 & 235 \\
\hline $0037 \mathrm{f}$ & 连 ngaeH & 302 & 259 \\
\hline $0039-$ & 筪 pae & not in Gong 1995 & 226 \\
\hline $0041 \mathrm{~d}$ & 眾 $k u$ & 296 & 226 \\
\hline 0044- & 樺 hwaeH & 304 & 250 \\
\hline $0045 c^{\prime}$ & 睹 $t u X$ & 294 & 242 \\
\hline $0049 a^{\prime}$ & 胡 $h u$ & 298 & 233 \\
\hline $0049 \mathrm{~m}$ & 罟 $k u X$ & 296 & 226, n. 88 \\
\hline $0049 u$ & 苦 $k h u X$ & 1,297 & 240 \\
\hline
\end{tabular}

${ }^{111}$ Gong's comparison 103 involves only Burmese and Tangut cognates and thus falls outside of the scope of this investigation. 


\begin{tabular}{|c|c|c|c|}
\hline GSR number & Chinese & Gong 1995 number & Number here \\
\hline $0053 a$ & 戶 $h u X$ & 30,303 & 248 \\
\hline $0058 \mathrm{a}$ & 五 $n g u X$ & 2,301 & 239 \\
\hline $0058 \mathrm{f}$ & 吾 $n g u$ & $3,96,300$ & 238 \\
\hline $0069 \mathrm{~g}$ & 盧 $p j u$ & not in Gong 1995 & 260 \\
\hline $0076 \mathrm{a}$ & 呂 $\operatorname{ljoX}$ & 312 & 234 \\
\hline $0077 \mathrm{a}$ & 旅 l ljoX & 313 & 230 \\
\hline $0079 a$ & 魚 ngjo & 314 & 244 \\
\hline $0094 a$ & 女 $n$ rjoX & 311 & 245 \\
\hline $0094 \mathrm{~g}$ & 如 nyo & 309 & 229 \\
\hline $0094 \mathrm{j}$ & 汝 nyoX & $5,97,310$ & 261 \\
\hline $0097 a$ & 于 $h j u$ & 38,316 & 247 \\
\hline 00970 & 样 $h j u H$ & 318 & 251 \\
\hline $0098 \mathrm{a}$ & 羽 $h j u X$ & 37,317 & 249 \\
\hline $0101 \mathrm{a}$ & 夫 $b j u$ & 306 & 232 \\
\hline $0102 a$ & 父 bjuX & 4,307 & 237 \\
\hline $0102 c^{\prime}$ & 補 $p u X$ & 293 & 236 \\
\hline $0103 a$ & 無 $m j u$ & 308 & 243 \\
\hline $0111 \mathrm{a}$ & 寇 khuwH & 320 & 195 \\
\hline $0113 \mathrm{e}$ & 候 huwH & 278 & 198 \\
\hline $0122 \mathrm{~g}$ & 軀 khju & 71,324 & 193 \\
\hline $0129 \mathrm{~g}$ & 住 drjuH & 15,284 & 197 \\
\hline 0134d & 孺 $n y u H$ & 323 & 196 \\
\hline $0135 \mathrm{a}$ & 乳 $n y u X$ & $16,70,95,322$ & 194 \\
\hline 0139- & 㽬 $x a n$ & 142 & 320 \\
\hline $0139 a$ & 干 kan & 88,141 & 318, n. 106 \\
\hline $0139 \mathrm{i}^{\prime}$ & 捍 $h a n H$ & 88,141 & 318 \\
\hline $0139 \mathrm{k}$ & 竿 $k a n$ & 178 & 315 \\
\hline 01391 & 肝 kan & 87,140 & 319 \\
\hline $0139 q$ & 扞 hanH & 88,141 & 318 \\
\hline $0139 \mathrm{~s}$ & 旱 $\operatorname{han} X$ & 194 & 324, n. 109 \\
\hline $0140 c$ & 乾 kan & 194 & 324 \\
\hline 01471 & 㲥 $\tan X$ & 175 & 317 \\
\hline $0148 \mathrm{~s}$ & 顫 syen & 183 & 312 \\
\hline $0150 \mathrm{a}$ & 丹 $\tan$ & 176 & 311 \\
\hline $0150 c$ & 斿 tsyen & 182 & 313 \\
\hline $0151 \mathrm{a}$ & 炭 than $H$ & 139 & 305 \\
\hline
\end{tabular}


內藤丘

Nathan W. Hill

\begin{tabular}{|c|c|c|c|}
\hline GSR number & Chinese & Gong 1995 number & Number here \\
\hline $0152 \mathrm{~d}$ & 難 nan & 177 & 316 \\
\hline $0153 \mathrm{~h}$ & 鑽 $t$ tswan & 42,197 & 191 \\
\hline $0154 \mathrm{~b}$ & 粲 $t$ shanH & 179 & 314 \\
\hline $0154 \mathrm{c}$ & 餐 tshan & 143 & 321 \\
\hline $0155 \mathrm{c}$ & 殘 $d z a n$ & 195 & 303 \\
\hline $0156 \mathrm{~d}$ & 靇 $\operatorname{sen} H$ & 59,187 & 63 \\
\hline $0157 \mathrm{f}$ & 涫 kwanH & 145 & 189 \\
\hline 01571 & 倌 kwaenH & 144 & 175 \\
\hline $0164 \mathrm{~m}$ & 垣 hjwon & 111,331 & 323 \\
\hline $0172 a$ & 段 twanH & not in Gong 1995 & 181 \\
\hline $0174 a$ & 算 $\operatorname{swanH}$ & 181 & 227 \\
\hline $0179 a$ & 卵 lwanX & 41 & 177 \\
\hline $0181 \mathrm{a}$ & 半 panH & 173 & 306 \\
\hline $0194 a$ & 產 sreanX & 60,151 & 3 \\
\hline 0201a & 展 trjen $X$ & 148 & 47 \\
\hline $0204 c$ & 纏 drjen & 184 & 307 \\
\hline $0205 \mathrm{f}$ & 縜 dzyen $H$ & 196 & 49 \\
\hline $0209 a$ & 鮮 sjen & 59,186 & 50 \\
\hline $0213 a$ & 連 ljen & 147 & 304 \\
\hline $0235 b$ & 膗 tsjwenX & not in Gong 1995 & 182 \\
\hline $0235 \mathrm{c}$ & 鐎 tsjwen & 42,197 & 191, n. 75 \\
\hline $0246 b$ & 徧 penH & 56,150 & 62 \\
\hline $0246 \mathrm{~h}$ & 偏 phijien & 146 & 48 \\
\hline $0252 \mathrm{e}$ & 獻 $s a$ & 185 & 322 \\
\hline $0255 \mathrm{e}$ & 援 hjwon & 149 & 310 \\
\hline 02551 & 緩 $h$ wanX & 180 & 309 \\
\hline $0262 \mathrm{j}$ & 板 paenX & 174 & 308 \\
\hline $0277 \mathrm{a}$ & 末 $m a t$ & 208 & 297 \\
\hline $0281 \mathrm{a}$ & 八 peat & 212 & 45 \\
\hline $0291 \mathrm{f}$ & 裂 ljet & 209 & 46, n. 31 \\
\hline $0292 \mathrm{a}$ & 別 bjet & 209 & 46 \\
\hline $0295 \mathrm{~b}$ & 経 trjwet & 44,215 & 186 \\
\hline $0296 a$ & 絶 dzjwet & 46,216 & 173 \\
\hline 03020 & 話 hwaejH & 34,118 & 299 \\
\hline $0303 \mathrm{e}$ & 越 hjwot & 36,210 & 300 \\
\hline $0319 \mathrm{~d}$ & 殺 sreat & not in Gong 1995 & 298 \\
\hline
\end{tabular}




\begin{tabular}{|c|c|c|c|}
\hline GSR number & Chinese & Gong 1995 number & Number here \\
\hline $0324 \mathrm{~m}$ & 脫 thwat & 39,213 & 174 \\
\hline 03240 & 悅 ywet & 40,214 & 187 \\
\hline $0339 \mathrm{~g}$ & 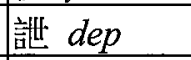 & 375 & 290 \\
\hline $0340 \mathrm{~g}$ & 糲 ljejH & not in Gong 1995 & 301 \\
\hline $0343 a$ & 贅 $t$ sywejH & 44,215 & 186, n. 73 \\
\hline $0351 \mathrm{c}$ & 蜾 $k w a X$ & 117 & 180 \\
\hline $0351 \mathrm{~d}$ & 裹 $k w a X$ & not in Gong 1995 & 192 \\
\hline $0353 a$ & 火 $x w a X$ & 17,134 & 126, cf. n. 55 \\
\hline $0359 \mathrm{c}$ & 邇 nyeX & not in Gong 1995 & 116 \\
\hline $0362 \mathrm{a}$ & 田 den & not in Gong 1995 & 32 \\
\hline $0364 \mathrm{a}$ & 年 nen & 251 & 29 \\
\hline $0374 a$ & 塵 drin & 158 & 109 \\
\hline $0381 \mathrm{a}$ & 盡 $d z i n X$ & 200 & 35 \\
\hline $0382 \mathrm{a}$ & 辛 $\sin$ & 82,201 & 37 \\
\hline $0382 \mathrm{k}$ & 新 $\sin$ & 93,259 & 33 \\
\hline $0382 n$ & 新 $\sin$ & 92,258 & 30 \\
\hline 03871 & 憐 len & 81,198 & 28 \\
\hline $0388 \mathrm{f}$ & 仁 nyin & 255 & 31 \\
\hline $0389 \mathrm{q}$ & 顝 bjinX & 199 & 34 \\
\hline $0393 a$ & 吉 kjit & 219 & 38 \\
\hline $0394 \mathrm{a}$ & 二 'jit & 83,220 & 41 \\
\hline $0399 \mathrm{e}$ & 節 $t$ set & $6,78,98,272$ & 23 \\
\hline $0400 \mathrm{a}$ & 七t tshit & 85,218 & 40 \\
\hline $0400 \mathrm{f}$ & 切 tshet & 86,217 & 39 \\
\hline 0401a & 桼 $t$ shit & 129 & 27 \\
\hline 0404a & 日 nyit & 8,127 & 26 \\
\hline 0416- & 齦 $n g j i$ & not in Gong 1995 & 123 \\
\hline $0416-$ & 䫀 $\operatorname{kon} X$ & 153 & 112 \\
\hline $0416 \mathrm{~b}$ & 根 kon & 152 & 111 \\
\hline $0416 \mathrm{k}$ & 銀 ngin & 89,160 & 110 \\
\hline $0422 \mathrm{~d}$ & 訓 $x j u n H$ & 162 & 157 \\
\hline $0427 i$ & 鈍 $d w o n H$ & 154 & 158, n. 64 \\
\hline $0430 \mathrm{a}$ & 尊 tswon & 204 & 154 \\
\hline $0434 a$ & 孫 swon & 206 & 168 \\
\hline $0438 \mathrm{a}$ & 奔 pwon & 202 & 164 \\
\hline $0457 \mathrm{k}$ & 昏 $x w o n$ & 203 & 155 \\
\hline
\end{tabular}




\begin{tabular}{|c|c|c|c|}
\hline GSR number & Chinese & Gong 1995 number & Number here \\
\hline $0457 \mathrm{~m}$ & 婚 $x$ won & not in Gong 1995 & 95 \\
\hline $0458 \mathrm{k}$ & 煇 $x j w i j$ & 171 & 101 \\
\hline 04581 & 輝 $x j w i j$ & 171 & 101 \\
\hline $0459 \mathrm{~g}$ & 郡 giunH & 161 & 165 \\
\hline $0462 \mathrm{c}$ & 順 $z y w i n H$ & 159 & 156 \\
\hline $0463 \mathrm{c}$ & 尞 $t s y h w i n X$ & 154 & 158 \\
\hline $0471 \mathrm{a}$ & 分 pjun & 155 & 114 \\
\hline $0471 \mathrm{~d}$ & 粉 pjunX & 189 & 115 \\
\hline $0471 \mathrm{ef}$ & 永肳 pjun & 188 & 116, n. 52 \\
\hline $0471 \mathrm{v}$ & 貧 $b$ in & 156 & 113 \\
\hline $0472 \mathrm{a}$ & 凟 pjunH & 205 & 163 \\
\hline $0473 a$ & 奮 pjunH & 188 & 116, n. 52 \\
\hline $0474 a$ & 焚 bjun & 190 & 94 \\
\hline $0478 \mathrm{~h}$ & 銑 $\operatorname{sen} X$ & 55,191 & 129 \\
\hline $0478 \mathrm{j}$ & 洗 $\operatorname{sej} X$ & 54,172 & 100 \\
\hline $0480 \mathrm{r}$ & 饉 $\operatorname{gin} H$ & 207 & 130 \\
\hline $0490 \mathrm{a}$ & 卒 $t$ swit & 221 & 162 \\
\hline $0496 \mathrm{~s}$ & 掘 gjwot & 27,222 & 188 \\
\hline $0498 \mathrm{a}$ & 率 lwit & not in Gong 1995 & 161 \\
\hline 0498- & 繂 lwit & not in Gong 1995 & 161 \\
\hline $0506 \mathrm{a}$ & 蟲 srit & 94,273 & 24 \\
\hline $0511 \mathrm{a}$ & 對 twojH & 381 & 88, n. 44 \\
\hline $0518 \mathrm{a}$ & 四 $s i j H$ & 131 & 15 \\
\hline $0521 \mathrm{a}$ & 界 pjijH & 124 & 22 \\
\hline $0523 a$ & 胃 hjwijH & 29,223 & 96 \\
\hline $0529 \mathrm{a}$ & 類 $l w i j H$ & 138 & 169 \\
\hline $0542 \mathrm{a}$ & 回 $h w o j$ & 26,193 & 99 \\
\hline $0547 \mathrm{a}$ & 幾 $k j i j X$ & 137 & 97 \\
\hline $0558 \mathrm{a}$ & 死 sijX & $11,91,130$ & 14 \\
\hline $0560 \mathrm{a}$ & 矢 syijX & not in Gong 1995 & 19 \\
\hline $0561 d$ & 屎 syijX & 10,128 & 21 \\
\hline $0564 a$ & 三 nyijH & $9,84,126$ & 13 \\
\hline $0566 \mathrm{~h}^{\prime}$ & 貔 $b j i j$ & 125 & 16 \\
\hline $0566 n$ & 妣 pjijX & 122 & 18 \\
\hline $0570 \mathrm{a}$ & 歸 kjwij & 26,193 & 99 \\
\hline $0571 \mathrm{~d}$ & 違 hjwij & not in Gong 1995 & 98 \\
\hline
\end{tabular}




\begin{tabular}{|c|c|c|c|}
\hline GSR number & Chinese & Gong 1995 number & Number here \\
\hline $0572 \mathrm{a}$ & 遣 $x j w i j \mathrm{j} X$ & 90,157 & 159 \\
\hline $0576 \mathrm{a}$ & 水 sywijX & 133 & 160 \\
\hline $0580 \mathrm{a}$ & 飛 $p j i j$ & 192 & 116 \\
\hline $0583 a$ & 尾 mjijjX & 136 & 128 \\
\hline $0583 \mathrm{e}$ & 娓 $x j w i j X$ & 20,135 & 126 \\
\hline $0590 \mathrm{a}$ & 氐 $t e j X$ & 169 & 20 \\
\hline $0594 \mathrm{~g}$ & 酒 $\operatorname{sej} X$ & 170 & 100 \\
\hline $0602 a$ & 几 $k i j X$ & 132 & 124 \\
\hline $0609 \mathrm{k}$ & 藍 lam & 356 & 292 \\
\hline $0611 \mathrm{c}$ & 慙 $d z a m$ & 357 & 1 \\
\hline 06171 & 談 dam & 355 & 293 \\
\hline 0619k & 擔 $\operatorname{tam}$ & 354 & 294 \\
\hline $0629 a$ & 甲 kaep & 373 & 288 \\
\hline $0633 \mathrm{~g}$ & 牒 dep & 58,378 & 59 \\
\hline $0633 \mathrm{~h}$ & 蝶 $d e p$ & 57,377 & 61 \\
\hline $0635 \mathrm{e}$ & 接 $t$ sjep & 376 & 289 \\
\hline $0642 q$ & 蓋 $k a j H$ & 374 & 291 \\
\hline $0648 \mathrm{a}$ & 三sam & 13,366 & 153 \\
\hline $06511^{\prime}$ & 含 hom & 370 & 89 \\
\hline $0651 \mathrm{n}$ & 擒 $\mathrm{gim}$ & 362 & 120 \\
\hline $0651 \mathrm{v}$ & 或 $k h o m$ & 365 & 105 \\
\hline $0653-$ & 窨 'imH & not in Gong 1995 & 121 \\
\hline $0655 \mathrm{k}$ & 禁 $\operatorname{kimH}$ & 361 & 117 \\
\hline $0656 a$ & 宎 $y \mathrm{im}$ & $106,112,369$ & 83 \\
\hline $0656 \mathrm{~b}$ & 沈 drim & 359 & 118 \\
\hline $0658 q$ & 䝾 khom & 365 & 105 \\
\hline $0661 \mathrm{f}$ & 垭 $t$ shimX & 364 & 42 \\
\hline $0661 \mathrm{~m}$ & 浸 $t \operatorname{sim} H$ & 363 & 43 \\
\hline $0662 \mathrm{a}$ & 尋 $\mathrm{zim}$ & 367 & 104,106 \\
\hline $0663 a$ & 心 $\operatorname{sim}$ & 372 & 91 \\
\hline $0667 \mathrm{i}$ & 娃 nyimH & 368 & 107 \\
\hline $0667 \mathrm{k}$ & 姙 nyimH & 368 & 107 \\
\hline $0667 q$ & 恁 nyimX & 371 & 85 \\
\hline $0668 \mathrm{a}$ & 禀 $\lim X$ & 358 & 44 \\
\hline $0668 \mathrm{~d}$ & 懔 $\lim X$ & 360 & 119 \\
\hline $0671 n$ & 箴 $t$ syim & not in Gong 1995 & 84 \\
\hline
\end{tabular}


内藤丘

Nathan W. Hill

\begin{tabular}{|c|c|c|c|}
\hline GSR number & Chinese & Gong 1995 number & Number here \\
\hline 06710 & 銊 tsyim & not in Gong 1995 & 84 \\
\hline $0674 a$ & 熊 hjuwng & not in Gong 1995 & 93 \\
\hline $0675 \mathrm{a}$ & 合 hop & 382 & 215 \\
\hline $0675 \mathrm{e}$ & 䢔 hop & 383 & 216 \\
\hline $0675 \mathrm{~m}$ & 洽 heap & 379 & 214 \\
\hline $0676 \mathrm{a}$ & 答 top & 381 & 88 \\
\hline $0681 \mathrm{~h}$ & 波 kip & $23,107,387$ & 87 \\
\hline $0690-$ & 摺 $t$ syep & 384 & 66 \\
\hline $0690 \mathrm{a}$ & 習 zip & 385 & 90 \\
\hline $0694 a$ & 立 $\operatorname{lip}$ & 108,386 & 86 \\
\hline $0694 \mathrm{~h}$ & 泣 khip & 388 & 89 \\
\hline $0695 \mathrm{a}$ & $\lambda$ nyip & 380 & 108 \\
\hline $0697 \mathrm{a}$ & 周 kang & 229 & 283 \\
\hline $0708-$ & 惶 hwang & 235 & 286 \\
\hline $0708 \mathrm{a}$ & 皇 hwang & 32,234 & 285 \\
\hline $0720 \mathrm{e}$ & 陽 yang & 227 & 274 \\
\hline $0720 \mathrm{j}$ & 揚 yang & 226 & 270 \\
\hline $0720 \mathrm{q}$ & 楊 yang & 228 & 268 \\
\hline $0721 \mathrm{~h}$ & 張 trjang & 241 & 264 \\
\hline $0725 \mathrm{~m}$ & 㪍 tsyhang $X$ & 240 & 265 \\
\hline $0727 f^{\prime}$ & 感 tsang & 232 & 275 \\
\hline $0727 g^{\prime}$ & 藏 dzangH & 233 & 280 \\
\hline $0727 \mathrm{~V}$ & 獎 tsjang & 249 & 276 \\
\hline $0728 \mathrm{a}$ & 象 zjang $X$ & 245 & 263 \\
\hline $0730 \mathrm{e}$ & 攘 nyang & 243 & 271 \\
\hline $0730 \mathrm{f}$ & 瀼 nyang & 242 & 188 \\
\hline $0730 \mathrm{i}$ & 讓 nyangH & 244 & 277 \\
\hline $0730 \mathrm{k}$ & 晎 nang $X$ & 101,225 & 135 \\
\hline $0735 \mathrm{a}$ & 良 ljang & 248 & 262 \\
\hline $0737 \mathrm{a}$ & 量 ljang & 247 & 279 \\
\hline $0739 \mathrm{k}$ & 往 hjwang $X$ & 102 & 287 \\
\hline $0740 \mathrm{i}$ & 放 pjang $H$ & 236 & 284 \\
\hline $0740 q$ & 妨 phjang & 237 & 273 \\
\hline $0740 \mathrm{r}$ & 紡 phjang $X$ & 238 & 282 \\
\hline $0740 \mathrm{y}$ & 房 bjang & 239 & 266 \\
\hline $0745 \mathrm{e}$ & 梗 kaengX & 230 & 281 \\
\hline
\end{tabular}




\begin{tabular}{|c|c|c|c|}
\hline GSR number & Chinese & Gong 1995 number & Number here \\
\hline $0748 \mathrm{a}$ & 行 haeng & 231 & 267 \\
\hline 07551 & 涼 ljang & 246 & 278 \\
\hline 07660 & 絡 lak & 268 & 254 \\
\hline $0778 \mathrm{~b}$ & 算 kjwak & 35,270 & 255 \\
\hline 0781a & 百 paek & not in Gong 1995 & 131 \\
\hline 07820 & 魄 phaek & not in Gong 1995 & 134 \\
\hline $0784 \mathrm{k}$ & 護 $h u H$ & 31,305 & 256 \\
\hline 0793a & 赤 $t$ syhek & not in Gong 1995 & 252 \\
\hline $0800 \mathrm{j}$ & 夜 yaeH & not in Gong 1995 & 253 \\
\hline $0801 \mathrm{~b}$ & 渡 $d u H$ & 295 & 132 \\
\hline $0805 \mathrm{~h}$ & 惡 'ak & 269 & 258 \\
\hline $0807-$ & 㬿 dzyaeH & 315 & 273 \\
\hline $0807 a$ & 射 zyek & not in Gong 1995 & 133 \\
\hline $0811 \mathrm{a}$ & 爭 tsreang & $7,99,253$ & 54 \\
\hline $0812 \mathrm{~g}$ & 甥 sraeng & 256 & 56 \\
\hline $0815 a$ & 盈 yeng & 252 & 57 \\
\hline $0819 \mathrm{a}$ & 井 tsjeng $X$ & 257 & 55 \\
\hline $0826 a$ & 名 mjieng & 77,254 & 53 \\
\hline $0841 \mathrm{a}$ & 冥 meng & 250 & 58 \\
\hline $0849 \mathrm{~g}$ & 縊 'ejH & 274 & 25 \\
\hline $0866 \mathrm{a}$ & 是 $d z y e X$ & 319 & 64 \\
\hline $0874 f$ & 髀 pjijX & 123 & 17 \\
\hline $0877-$ & 滴 tek & 271 & 52 \\
\hline $0884 d$ & 憎 tsong & 265 & 81 \\
\hline 0890e & 倠 'ing & not in Gong 1995 & 79 \\
\hline $0892 a$ & 蠅 ying & 224 & 80 \\
\hline $0892 b$ & 繩 zying & not in Gong 1995 & 125 \\
\hline $0896 \mathrm{k}$ & 蒸 tsying & 267 & 82 \\
\hline $0902 \mathrm{a}$ & 夢 mjuwngH & 21,266 & 78 \\
\hline $0904 a$ & 黑 $x o k$ & 287 & 76 \\
\hline $0904 \mathrm{c}$ & 墨 $m o k$ & 287 & 76, n. 38 \\
\hline $0907 \mathrm{a}$ & 賊 $d z o k$ & 290 & 73 \\
\hline 0920f & 織 $t s y i k$ & 291 & 74 \\
\hline $0925 \mathrm{a}$ & 息 $s i k$ & 292 & 102 \\
\hline $0937 \mathrm{a}^{\prime}$ & 核 heak & 289 & 75 \\
\hline $0947 \mathrm{a}$ & 母. $m u w X$ & 325 & 70 \\
\hline
\end{tabular}


內藤丘

Nathan W. Hill

\begin{tabular}{|c|c|c|c|}
\hline GSR number & Chinese & Gong 1995 number & Number here \\
\hline $0952 a$ & 其 $g i$ & not in Gong 1995 & 122 \\
\hline 0954d & 翼 yik & $19,109,288$ & 77 \\
\hline 0964a & 子 $t s i X$ & 327 & 69 \\
\hline $0966 \mathrm{j}$ & 慈 $d z i$ & 328 & 68 \\
\hline $0966 \mathrm{k}$ & 卒 $d z i H$ & 328 & 68, n. 33 \\
\hline 0971a & 事 $d z r i H$ & 329 & 71 \\
\hline $0981 \mathrm{a}$ & 耳 $n y i X$ & 22,326 & 67 \\
\hline $0992 a$ & 九 kjuwX & $24,63,352$ & 138 \\
\hline $0992 n$ & 䲨 kjuw & 62,351 & 139 \\
\hline $0995 \mathrm{e}$ & 友 hiuwX & 28,330 & 72 \\
\hline $1006 \mathrm{f}$ & 躬 kjuwng & 69,332 & 152 \\
\hline $1016 a$ & 毒 dowk & $18,65,338$ & 147 \\
\hline $1019 \mathrm{~g}$ & 篤 towk & 337 & 144 \\
\hline $1024 a$ & 弹 tsyuwk & 341 & 150 \\
\hline $1032 a$ & 六 ljuwk & 68,342 & 146 \\
\hline 10341 & 愎 phjuwH & 67,340 & 151 \\
\hline $1037 \mathrm{a}$ & 牧 $m j u w k$ & not in Gong 1995 & 103 \\
\hline $1038 \mathrm{f}$ & 覺 kaewk & 66,339 & 146 \\
\hline $1038 \mathrm{i}$ & 攪 kaewX & 66,339 & 146, n. 57 \\
\hline $1040 \mathrm{~d}$ & 嚊 haw & 349 & 140 \\
\hline $1041 q$ & 號 haw & 50,347 & 220 \\
\hline $1048 \mathrm{a}$ & 道 $d a w X$ & 112,369 & $83, \mathrm{n}$. \\
\hline $1048 \mathrm{~d}$ & 導 $d a w H$ & 112 & $83, \mathbf{n}$. \\
\hline $1067 \mathrm{~b}$ & 舅 gjuwX & $25,64,353$ & 137 \\
\hline $1069 \mathrm{r}$ & 醪 law & 49,345 & 228 \\
\hline $1073 a$ & 肘 trjuwX & 350 & 141 \\
\hline $1075 a$ & 畫 $\operatorname{trjuwH}$ & 283 & 145 \\
\hline $1079 a$ & 由 $y u w$ & $106,112,369$ & 83, n. 41 \\
\hline $1096 \mathrm{r}$ & 猶 yuw & $106,112,369$ & 83, n. 41 \\
\hline $1104 a$ & 流 ljuw & not in Gong 1995 & 142 \\
\hline $1105 \mathrm{a}$ & 柔 nyuw & 390 & 143 \\
\hline $1105 \mathrm{~b}$ & 揉 nyuw & 390 & 143, n. 60 \\
\hline $1109 \mathrm{t}$ & 霧 $m j u H$ & 280,321 & 204 \\
\hline $1113 \mathrm{~b}$ & 胞 paew & 61,348 & 136 \\
\hline $1119 \mathrm{f}$ & 㷍 $y a k$ & 52,334 & 224, n. 85 \\
\hline $1123 a$ & 弱 nyak & 51,336 & 223 \\
\hline
\end{tabular}




\begin{tabular}{|c|c|c|c|}
\hline GSR number & Chinese & Gong 1995 number & Number here \\
\hline $1124 \mathrm{i}$ & 曜 yewH & 52,334 & 224 \\
\hline $1124 j$ & 燿 yewH & 52,334 & 224 \\
\hline $1124 \mathrm{k}$ & 耀 yewH & 52,334 & 224 \\
\hline $1127 \mathrm{a}$ & 駁 paewk & 333 & 222 \\
\hline $1128 \mathrm{a}$ & 鐾 $d z a k$ & 335 & 221 \\
\hline $1129 n$ & 豪 haw & 346 & 219 \\
\hline $1137 \mathrm{~h}$ & 耄 maw & 47,343 & 122 \\
\hline $1144 j$ & 謠 yew & 48,344 & 218 \\
\hline $1172 \mathrm{~h}$ & 空 khuwng & $75,79,263$ & 212 \\
\hline $1174 a$ & 孔 khuwngX & $75,79,263$ & 212, n. 81 \\
\hline $1185 q$ & 痛 thuwngH & 261 & 208 \\
\hline $1188 f^{\prime}$ & 撞 draewng & 262 & 209 \\
\hline $1197 \mathrm{~s}$ & 蜂 phjowng & $12,100,260$ & 211 \\
\hline $1197 \mathrm{t}$ & 蠚 phjowng & $12,100,260$ & 211 \\
\hline $1199 \mathrm{~g}$ & 萝 tshuwng & not in Gong 1995 & 185 \\
\hline $1202 \mathrm{a}$ & 谷 $k u w k$ & 110 & 206 \\
\hline $1213 a$ & 曲 khjowk & $74,80,286$ & 199 \\
\hline $1218 \mathrm{c}$ & 㭬 traewk & 72,276 & 203 \\
\hline $1218 \mathrm{~h}$ & 冢 trjowng $X$ & 76,264 & 210 \\
\hline $1220 \mathrm{a}$ & 俗 zjowk & 285 & 205 \\
\hline 12220 & 欶 sraewk & 279 & 207 \\
\hline $1224 \mathrm{e}$ & 燭 tsyowk & $14,73,281$ & 201 \\
\hline $1224 \mathrm{~g}$ & 觸 tsyhowk & 282 & 202 \\
\hline $1226 a$ & 殼 khaewk & not in Gong 1995 & 179 \\
\hline $1226 \mathrm{i}$ & 谼 $k u w k$ & 277 & 200 \\
\hline $1255 \mathrm{a}$ & 疊 $d e p$ & 53,389 & 60 \\
\hline $1260 \mathrm{c}$ & 隻 tsyek & not in Gong 1995 & 51 \\
\hline
\end{tabular}




\section{References}

Arisaka, Hideyo. 有坂秀世. 1937-1939.〈カールグレン氏の拗音説を詊す〉， 《音声学協会会報》49:11-15；51:8-9；53:4；58:8-10. 又收錄於有坂秀世. 1957. 《國語音韻史の研究》増補新版 327-357。東京：三省堂。

Arisaka, Hideyo. 有坂秀世. 1961. A critical study of Karlgren's medial i theory. Memoirs of the Research Department of the Tōyo Bunko 21:49-75.

Baxter, William H. 1980. Some proposals on Old Chinese phonology. Contributions to Historical Linguistics: Issues and Materials, ed. by Frans van Coetsem, and Linda R. Waugh, 1-33. Leiden: Brill.

Baxter, William H. 1992. A Handbook of Old Chinese Phonology. Berlin: Mouton de Gruyter.

Baxter, William H., and Laurent Sagart. 2011. Baxter-Sagart Old Chinese Reconstruction (Version 1.00). Online at http://crlao.ehess.fr/document.php?id= $\underline{1217}$.

Beckwith, Christopher I. 2008. Old Chinese loans in Tibetan and the non-uniqueness of "Sino-Tibetan". Medieval Tibeto-Burman Languages III, ed. by Christopher Beckwith, 61-201. Halle: International Institute for Tibetan and Buddhist Studies GmbH.

Benedict, Paul. 1939. Semantic differentiation in Indo-Chinese. Harvard Journal of Asiatic Studies 4.3-4:213-229.

Bodman, Nicholas. 1971. A phonological system for Old Chinese. Paper presented to the Chinese Linguistics Project, Princeton University.

Bodman, Nicholas. 1980. Proto-Chinese and Sino-Tibetan: data toward establishing the nature of the relationship. Contributions to Historical Linguistics: Issues and Materials, ed. by Frans van Coetsem, and Linda R. Waugh, 34-199. Leiden: Brill.

Coblin, W. South. 1976. Notes on Tibetan verbal morphology. T'oung Pao 52:45-70.

Dempsey, Jakob. 2001. Remarks on the vowel system of old Burmese. Linguistics of the Tibeto-Burman Area 24.2:205-34. Errata 26.1:183.

Frasch, Tilman. 1996. Pagan: Stadt und Staat. Stuttgart: F. Steiner.

Gong Hwang-cherng. 1980. A comparative study of the Chinese, Tibetan, and Burmese vowel systems. Bulletin of the Institute of History and Philology 51.3: 455-490. Reprinted in: Gong Hwang-cherng. 2002. Collected Papers on SinoTibetan Linguistics, 1-30. Taipei: Institute of Linguistics (Preparative Office), Academia Sinica. 
Gong Hwang-cherng. 1995. The system of finals in proto-Sino-Tibetan. The Ancestry of the Chinese Language, ed. by William S.-Y. Wang, 41-92. Journal of Chinese Linguistics Monograph Series Number 8. Reprinted in: Gong Hwang-cherng. 2002. Collected Papers on Sino-Tibetan Linguistics, 79-124. Taipei: Institute of Linguistics (Preparative Office), Academia Sinica.

Handel, Zev. 2009. Old Chinese Medials and their Sino-Tibetan Origins: A Comparative Study. Taipei: Institute of Linguistics, Academia Sinica.

Hill, Nathan W. 2005. Once more on the letter a. Linguistics of the Tibeto-Burman Area 28.2:111-141.

Hill. Nathan W. 2010. A Lexicon of Tibetan Verb Stems as Reported by the Grammatical Tradition. Munich: Bayerische Akademie der Wissenschaften.

Hill, Nathan W. 2011a. Multiple origins of Tibetan o. Language and Linguistics 12.3: 707-721.

Hill, Nathan W. 2011b. An inventory of Tibetan sound laws. Journal of the Royal Asiatic Society of Great Britain and Ireland (Third Series) 21.4:441-457.

Hill, Nathan W. 2012. Evolution of the Burmese vowel system. Transactions of the Philological Society 110.1:64-79.

Houghton, Bernard. 1898. Outlines of Tibeto-Burman linguistic palæontology. Journal of the Royal Asiatic Society 23-55.

Imaeda, Yoshiro, Tsuguhito Takeuchi, Izumi Hoshi, Yoshimichi Ohara, Iwao Ishikawa, Kazushi Iwao, Ai Nishida, and Brandon Dotson. 2007. Tibetan Documents from Dunhuang. Tokyo: Research Institute for Languages and Cultures of Asia and Africa, Tokyo University of Foreign Studies.

Iwao, Kazushi, Nathan W. Hill, and Tsuguhito Takeuchi. 2009. Old Tibetan Inscriptions. Tokyo: Research Institute for Languages and Cultures of Asia and Africa, Tokyo University of Foreign Studies.

Jacques, Guillaume. 2003. Un cas de dissimilation labiale en chinois archaique: la racine "couvrir, renverser" et son equivalent en Tibetain. Cahiers de Linguistique Asie Orientale 32.1:123-130.

Jacques, Guillaume, and Alexis Michaud. 2011. Approaching the historical phonology of three highly eroded Sino-Tibetan languages: Naxi, $\mathrm{Na}$ and Laze. Diachronica 28.4:468-498, online appendix 1-25.

Jäschke, Heinrich August. 1881. Tibetan English Dictionary. London: Unger Brothers. 
Jaxontov, Sergej Evgen'evič. 1960a. Consonant combinations in Archaic Chinese. Papers presented by the USSR delegation of the 25the International Congress of Orientalists, Moscow. Moscow: Oriental Literature Publishing House. Translation of: Сергей Евгеньевич Яхонтов. 1963. Сочетания согласных в древнекитайском языке. Труды двадуать пятого мељсународного конгресса востоковедов, Москва, 9-16 августа 1960г. Заседания секџий XVI-XX 5:89-95. Москва: Издательство Восточной Литературы.

Jaxontov, Sergej Evgen'ejvič. Яхонтов, Сергей Евгеньевич. 1960b. Фонетика китайского языка 1 тысячелетия до н. э. (лабиализованные гласные). Проблемы Востоковедения 6:102-115. English translation by Jerry Norman: Jaxontov, Sergej Evgen'ejvič. 1970. The phonology of Chinese of the first millennium B. C. (rounded vowels). Chi Lin / Unicorn 6:52-75.

Jaxontov, Sergej Evgen'ejvič. Яхонтов, Сергей Евгеньевич. 1965. Древнекитайский язык. Москва: Издательство Наука.

Jaxontov, Sergej Evgenejvič. 1978-1979. Old Chinese Phonology. Early China 4:3740.

de Jong, J. W. 1989. The Story of Räma in Tibet. Stuttgart: F. Steiner.

Karlgren, Bernhard. 1957. Grammata Serica Recensa. Stockholm: Museum of Far Eastern Antiquities.

Kojima, Noriyuki 小島憲之 et al. (eds.) 1994. 《日本書紀》。東京：小学館。

Laufer, Berthold. 1898-1899. Ueber das va zur. Ein Beitrag zur Phonetik der tibetischen Sprache. Wiener Zeitschrift für die Kunde des Morgenlandes 12:289307; 13:95-109, 199-226. Reprinted in: Hartmut Walravens. (ed.) 1976. Kleinere Schriften von Berthold Laufer, 61-122. Wiesbaden: Franz Steiner Verlag,

Li, Fang-Kuei. 1933. Certain phonetic influences of the Tibetan prefixes upon the root initials. Bulletin of the Institute of History and Philology 6.2:135-157.

Li, Fang-Kuei. 1959. Tibetan glo-ba-'dring. Studia Serica Bernhard Karlgren dedicate, ed. by Søren Egerod, and Else Glahn, 55-59. Copenhagen: Ejnar Munksgaard.

Li, Fang-Kuei. 李方桂. 1971. 〈上古音研究〉, 《清華學報》新 9: 1-61。English translation by Gilbert L. Mattos: Li, Fang-Kuei. 1974-75. Studies on Archaic Chinese. Monumenta Serica 31:219-87.

Luce, Gordon H. 1985. Phases of Pre-Pagán Burma: Languages and History. Oxford: Oxford University Press.

Matisoff, James. 2003. Handbook of Proto-Tibeto-Burman: System and Philosophy of Sino-Tibeto-Burman Reconstruction. Berkeley: University of California Press.

Maung Wun. 1975. Development of the Burmese language in the medieval period. 大 阪外国語大学学報 36: 63-119. 
Nishi, Yoshio. 西義郎. 1974.〈ビルマ文語の -acについて〉, 《東洋学報》56.1: $1-43$ 。

Nishi, Yoshio. 1999. Four Papers on Burmese: Toward the History of Burmese. Tokyo: Institute for the Study of Languages and Cultures of Asia and Africa, Tokyo University of Foreign Studies.

Nishida，Tatsuo. 西田龍雄. 1955.〈Myazedi 碑文に扔ける中古ビルマ語の研 究〉, 《古代學》4.1:17-31, 5.1:22-40。

Pan, Wuyun. 潘悟雲. 2000.《漢語歷史音韻學》。上海：上海敎育出版社。

Pulleyblank, Edwin G. 1962. The consonantal system of Old Chinese. Asia Major (New Series) 9:58-144, 206-265.

Pulleyblank, Edwin G. 1963. An interpretation of the vowel systems of Old Chinese and of written Burmese. Asia Major (New Series) 10.2:200-221.

Pulleyblank, Edwin G. 1979. The Chinese cyclical signs as phonograms. Journal of the American Oriental Society 99.1:24-38.

Pulleyblank, Edwin G. 2000. Morphology in Old Chinese. Journal of Chinese Linguistics 28.1:26-51.

Róna-Tas, András. 1966. Tibeto-Mongolica: the Tibetan Loanwords of Monguor and the Development of the Archaic Tibetan Dialects. The Hague: Mouton.

Sagart, Laurent. 1988. Nord et sud dans la langue et l'écriture des Shang. T'oung Pao 74.4-5:249-254.

Sagart, Laurent. 1999. The Roots of Old Chinese. Amsterdam: John Benjamins.

Sagart, Laurent, and William H. Baxter. 2009. Reconstructing old Chinese uvulars in the Baxter-Sagart system (Version 0.99). Cahiers de Linguistique - Asie Orientale 38.2:221-244.

Sagart, Laurent, and William H. Baxter. 2012. Reconstructing the $*_{s-}$ prefix in Old Chinese. Language and Linguistics 13.1:29-59.

Schiefner, Anton. 1852. Tibetischen studien. Mélanges asiatiques tirés du Bulletin de l'Académie impériale des sciences de St.-Pétersboug 1:324-394.

Schuessler, Axel. 1974. R and L in Archaic Chinese. Journal of Chinese Linguistics 2: 186-199.

Schuessler, Axel. 2007. ABC Etymological Dictionary of Old Chinese. Honolulu: University of Hawai ${ }^{\prime} i$ Press.

Schuessler, Axel. 2009. Minimal Old Chinese and Later Han Chinese. Honolulu: University of Hawai 'i press.

Shafer, Robert. 1940-1941. The vocalism of Sino-Tibetan. Journal of the American Oriental Society 60.3:302-337; 61.1:18-31. 
Simon, Walter. 1929. Tibetisch-Chinesische Wortgleichungen, ein Versuch. Mitteilungen des Seminars für Orientalische Sprachen an der Friedrich Wilhelms-Universität zu Berlin 32:157-228.

Starostin, Sergej Anatol'evič. Старостин, Сергей Анатольевич. 1989. Реконструкчия Древнекитайской Фонологической Системы. Москва: Издательство Наука.

Walter, Michael. 2009. Buddhism and Empire. Leiden: Brill.

Yanson, Rudolf. 2006. Notes on the evolution of the Burmese phonological system. Medieval Tibeto-Burman Languages II, ed. by Christopher I. Beckwith, 103-120. Leiden: Brill.

Zhengzhang, Shangfang. 2000. The Phonological System of Old Chinese. Paris: École des Hautes Études en Sciences Sociales, Centre de Recherches Linguistiques sur l'Asie Orientale. 


\title{
比較脈絡下的古漢語六元音假說
}

\begin{abstract}
內藤丘
倫敦大學亞非學院

壟煌城曾在兩篇文章 $(1980 ， 1995)$ 裏整理了一批漢語、藏語和緬語 的同源詞。本文將利用白一平及沙加爾的古漢語六元音構擬, 重新驗証這 批同源詞（根據㲔煌城 1995）。本文指出六元音理論可以使得部份同源詞 更加可信，同時能排除或修正其他的同源詞假設。
\end{abstract}

關鍵詞：上古漢語、古緬語、古藏語、元音 